ANTÍGENOS VARIANTES DE SUPERFÍCIE DE HEMÁCIAS INFECTADAS POR Plasmodium falciparum NA AMAZÔNIA BRASILEIRA: ADERÊNCIA A RECEPTORES DO ENDOTÉLIO VASCULAR (CD36 E ICAM-1) E RECONHECIMENTO POR ANTICORPOS

Tese apresentada ao Programa de PósGraduação em Biologia da Relação PatógenoHospedeiro do Instituto de Ciências Biomédicas da Universidade de São Paulo, para obtenção do Título de Doutor em Ciências. 


\section{ANTÍGENOS VARIANTES DE SUPERFÍCIE DE HEMÁCIAS INFECTADAS POR Plasmodium falciparum NA AMAZÔNIA BRASILEIRA: ADERÊNCIA A RECEPTORES DO ENDOTÉLIO VASCULAR (CD36 E ICAM-1) E RECONHECIMENTO POR ANTICORPOS}

Tese apresentada ao Programa de PósGraduação em Biologia da Relação PatógenoHospedeiro do Instituto de Ciências Biomédicas da Universidade de São Paulo, para obtenção do Título de Doutor em Ciências.

Área de Concentração: Biologia da Relação Patógeno-Hospedeiro

Orientador: Prof. Dr. Marcelo Urbano Ferreira

Co-orientador: Prof. Dr. Gerhard Wunderlich

Versão original 
DADOS DE CATALOGAÇÃO NA PUBLICAÇÃO (CIP)

Serviço de Biblioteca e Informação Biomédica do

Instituto de Ciências Biomédicas da Universidade de São Paulo

(C) reprodução total

Carlos, Bianca Cechetto.

Antígenos variantes de superfície de hemácias infectadas por Plasmodium falciparum na Amazônia brasileira: aderência a receptores do endotélio vascular (CD36 e ICAM-1) e reconhecimento por anticorpos / Bianca Cechetto Carlos. -- São Paulo, 2013.

Orientador: Prof. Dr. Marcelo Urbano Ferreira.

Tese (Doutorado) - Universidade de São Paulo. Instituto de Ciências Biomédicas. Departamento de Parasitologia. Área de concentração:

Biologia da Relação Patógeno-Hospedeiro. Linha de pesquisa: Malária.

Versão do título para o inglês: Variant surface antigens from Plasmodium falciparum-infected erythrocytes in Brasilian Amazon: adherence to endothelium receptors (CD36 and ICAM-1) and antibodies recognition.

$\begin{array}{llll}\text { 1. Plasmodium falciparum } & \text { 2. Citoaderência } & \text { 3. CD36 } & \text { 4. ICAM-1 }\end{array}$ 5. PfEMP-1 I. Ferreira, Prof. Dr. Marcelo Urbano II. Universidade de São Paulo. Instituto de Ciências Biomédicas. Programa de PósGraduação em Biologia da Relação Patógeno-Hospedeiro III. Título. 


\section{UNIVERSIDADE DE SÃO PAULO \\ INSTITUTO DE CIÊNCIAS BIOMÉDICAS}

Candidato(a): $\quad$ Bianca Cechetto Carlos.

Título da Tese: $\quad$ Antígenos variantes de superfície de hemácias infectadas por Plasmodium falciparum na Amazônia brasileira: aderência a receptores do endotélio vascular (CD36 e ICAM-1) e reconhecimento por anticorpos.

Orientador(a): $\quad$ Prof. Dr. Marcelo Urbano Ferreira.

A Comissão Julgadora dos trabalhos de Defesa da Tese de Doutorado, em sessão pública realizada a considerou
( ) Aprovado(a)
( ) Reprovado(a)

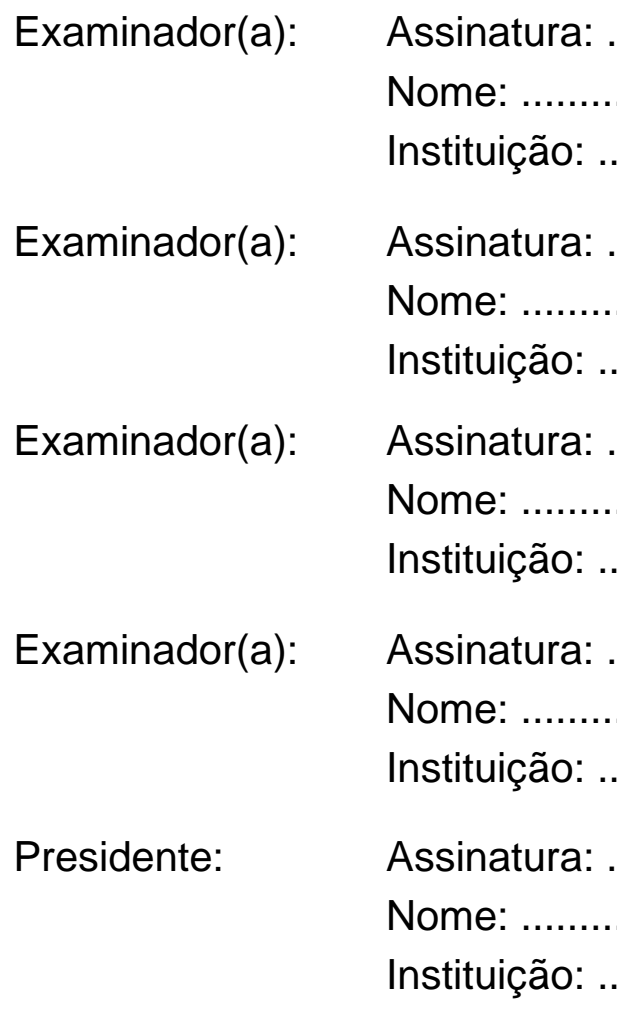


São Paulo, 19 de novembro de 2009.

\section{PARECER 928 /CEP}

A Comissão de Ética em Pesquisas com Seres Humanos do ICB, na sessão de 18.11.2009 APROvou o projeto intitulado: “Antígenos variantes de superfície de hemácias infectadas por Plasmodium falciparum na Amazômia brasileira: aderência receptores do endotélio vascular (CD36 e ICAM-1) e reconhecimento de anticorpos", sob responsabilidade de execução dos autores Prof. Dr. Marcelo Urbano Ferreira e a aluna Bianca CeChetto Carlos.

Cabe aos pesquisadores executantes elaborar e apresentar a este Comitê, relatórios anuais (parciais ou final), de acordo com a resolução 196/06 do Conselho Nacional da Saúde, item IX.2 letra c.

O primeiro relatório deverá ser encaminhado à Secretaria deste CEP em

18.11.2010

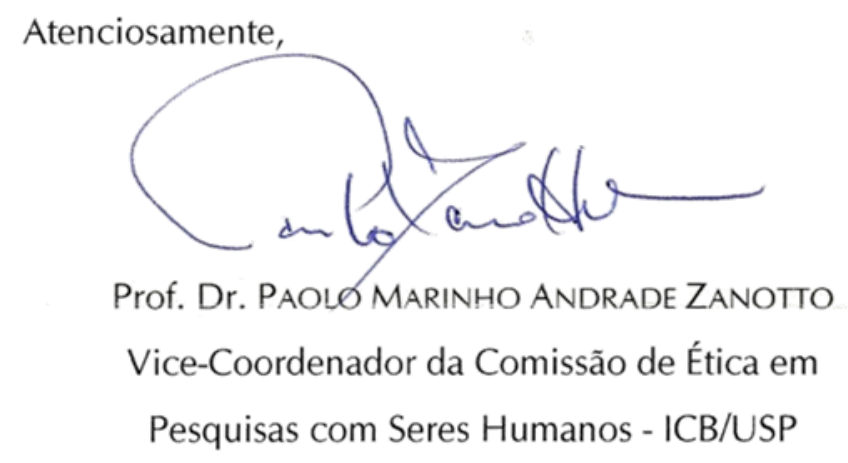




\section{AGRADECIMENTOS}

Agradeço a Deus, à família e aos amigos por todo amor, carinho, força e compreensão que me ajudaram muito a chegar até o fim desta etapa.

Agradeço ao meu orientador, Marcelo Urbano Ferreira, pela oportunidade do doutorado em seu laboratório, por seus ensinamentos que me possibilitaram crescer e enriquecer meus conhecimentos na área. Da mesma forma, agradeço ao meu co-orientador, Gerhard Wunderlich, com quem aprendi várias técnicas e teorias. Além, de ambos serem excelentes orientadores, também lhes reservo grande respeito e admiração como profissionais e como pessoa.

Agradeço ao meu orientador do mestrado, Paulo E. M. Ribolla, não só por ter me apresentado ao laboratório do Marcelo, mas também por sua grande contribuição à minha formação de hoje. Também Ihe reservo grande carinho e respeito.

Agradeço a todos que fizeram parte da minha formação, todos os professores que passaram pela minha vida até hoje no doutorado. Todos foram muito importantes! Aproveito a oportunidade para homenagear meu queridíssimo e eterno professor de biologia Roberto Farah, que nos deixou há anos, mas que sempre me recordo com carinho e saudades. Guardo com muito amor o livro de genética que ganhei no segundo colegial e que me despertou grande interesse pela biologia. Que Deus o ilumine onde estiver.

Seria uma imensa lista de nomes que eu gostaria de citar aqui, mas possivelmente eu esqueceria injustamente de alguém. Então, agradeço a toda equipe dos vários laboratórios: do prof. Dr. Marcelo U. Ferreira, do prof. Dr. Gerhard Wunderlich, do prof. Dr. Cláudio M Romero, do prof. Dr. Alejandro M. Katzin e do prof. Dr. Fábio T. M. Costa da UNICAMP. Desses laboratórios, agradeço em especial à Camila e à Suzana pela generosa doação de sangue aos meus experimentos e também à Maria José Menezes, Valnice e Wesley, que foram as pessoas que mais me ajudaram nesses 4 anos, ensinando técnicas e discutindo a resolução de problemas, sem falar na amizade.

Agradeço a todos os meus velhos amigos do coração, e a Deus por todos os amados amigos que fiz em São Paulo, tanto no laboratório, no ICB, no CEPE USP (em especial, aos professores Haroldo e Érica), quanto os moradores do caminho para a USP, e as meninas tão queridas e especiais com quem morei ou fui vizinha. 
Agradeço a todos do centro espírita A Casa do Caminho, por todas as orações, carinho e amizade de longa data. À minha família maravilhosa, que sempre me apoiou, nem tenho palavras para agradecer, mãe, pai e Ge, eu os amo demais! Obrigada pelo amor, pela educação que me deram e por todo suor que me possibilitou estar aqui hoje! Não ficam para trás meus amados tios, avós, cunhados, sobrinhos lindos e querida sogra. Obrigada a todos pelo lindo sentimento que nos une e que nos impulsiona juntos para frente! Ao meu noivo, meu amor, amigo e companheiro, Ricardo M. Bueno, obrigada pela sua paciência, seu respeito e incentivo, obrigada por todo seu amor. Cada domingo que eu te deixava para ir a São Paulo era sofrido, mas sua compreensão e sua força me ajudaram demais. Te amo!

Agradeço a Deus por todas as oportunidades, todas as pessoas e também por todos os bichinhos que colocou na minha vida, tornando-a mais alegre. Acho que a vida não teria tanta graça sem um gatinho para acariciar ou sem a festinha de um cachorro ao te reencontrar, espantando qualquer tristeza. Que o homem aprenda a amar, respeitar e a cuidar cada vez mais dessa preciosidade chamada natureza que o Senhor nos confiou. Obrigada! 
Este trabalho contou com o apoio financeiro da Fundação de Amparo à Pesquisa do Estado de São Paulo (FAPESP). 
"A ciência sem a religião é paralítica. A religião sem a ciência é cega".

Albert Einstein 


\section{RESUMO}

Carlos BC. Antígenos variantes de superfície de hemácias infectadas por Plasmodium falciparum na Amazônia brasileira: aderência a receptores do endotélio vascular (CD36 e ICAM-1) e reconhecimento por anticorpos. [tese (Doutorado em Parasitologia)]. São Paulo: Instituto de Ciências Biomédicas, Universidade de São Paulo; 2013.

A malária é uma das principais endemias parasitárias brasileiras, com 460.000 casos clínicos notificados em 2007. A relativa raridade de casos graves de malária no Brasil sugere que os isolados locais de Plasmodium falciparum tenham menor virulência que os parasitas africanos e asiáticos. A virulência de $P$. falciparum decorre em grande medida de sua capacidade de aderir a receptores do endotélio vascular, por meio de antígenos variantes de superfície (VSA) exportados para a membrana da hemácia infectada. Este trabalho investigou os padrões de aderência de sete isolados de $P$. falciparum, provenientes de uma área da Amazônia brasileira em que a malária grave é rara, a dois receptores do endotélio vascular, CD36 e ICAM-1. Também analisamos, na mesma área de origem dos parasitas, a resposta de anticorpos de indivíduos locais contra oitos antígenos de superfície, incluindo isolados de campo e a cepa 3D7. Mostramos que: (a) de modo geral, os isolados locais de $P$. falciparum expressam VSAs capazes de aderir tanto a ICAM-1 quanto a CD36, embora alguns possuam uma baixa ou nula capacidade de adesão; (b) detectamos anticorpos contra antígenos apresentados por isolados de campo e pela cepa 3D7 entre moradores de uma área endêmica próxima à origem dos isolados; (c) vimos que alguns dos soros testados foram capazes de bloquear a adesão de hemácias parasitadas a ICAM-1 e CD36, in vitro; (d) detectamos uma baixa prevalência do alelo $S$ (hemoglobina $S$ ) na população de estudo, corroborando com a hipótese de que essa hemoglobinopatia não representa um fator de seleção significativo de isolados locais de alta capacidade de aderência a receptores endoteliais.

Palavras-chave: Plasmodium falciparum. Citoaderência. CD36. ICAM-1. PfEMP1. 


\begin{abstract}
Carlos BC. Variant surface antigens from Plasmodium falciparum-infected erythrocytes in Brazilian Amazon: adherence to endothelium receptors (CD36 and ICAM-1) and antibodies recognition. [Ph. D. thesis (Parasitology)]. São Paulo: Instituto de Ciências Biomédicas, Universidade de São Paulo; 2013.

Malaria is one of the major parasitic endemic diseases in Brazil with 460,000 clinically notified cases in 2007. The relative rarity of severe malaria in Brazil suggests that the local Plasmodium falciparum isolates are less virulent than African and Asian parasites. $P$. falciparum virulence is mainly due to its ability to adhere to the vascular endothelium receptors through variant surface antigens (VSA) exported to the infected red blood cell membrane. This work investigated adherence patterns to CD36 and ICAM-1, two receptors of the vascular endothelium, in P. falciparum isolates from an area of the Brazilian Amazon, where severe malaria is rare. We also analyzed, in the same area, the antibody responses of people against eight VSAs. We found that: (a) local $P$. falciparum isolates express VSAs capable to adhere to both receptors, CD36 and ICAM-1, although in a few cases adherence is weak or absent; (b) we detected antibodies against VSAs in a human population exposed to malaria, expressed from local parasites and the 3D7 control; (c) we found in vitro that some sera contained naturally acquired antibodies which blocked the adherence of the parasitized RBCs to ICAM-1 and CD36; (d) we detected a low frequency of the S allele (hemoglobin S) in the study population. This supports the hypothesis that $\mathrm{HbS}$ do not represent a significant selection factor for high adherence capacity to endothelial receptors in these local isolates.
\end{abstract}

Keywords: Plasmodium falciparum. Cytoadherence. CD36. ICAM-1. PfEMP1. 


\section{LISTA DE ILUSTRAÇÕES}

Figura 1 - Distribuição mundial da malária em 2010.

Figura 2 - Fisiopatologia da malária grave e complicada por Plasmodium falciparum.

Figura 3 - Representação das moléculas envolvidas na adesão de hemácias infectadas por Plasmodium falciparum ao endotélio vascular.

Figura 4 - Representação esquemática da estrutura de PfEMP-1 na superfície da hemácia infectada.

Figura 5 - Localização do Ramal do Granada.

Figura 6 - Localização do PAD Pedro Peixoto no mapa do Estado do Acre. 34

Figura 7 - Porcentagem de reconhecimento dos soros aos isolados de campo por citometria de fluxo. .45

Figura 8 - Primeiro diagnóstico de citoaderência dos sete isolados de campo. . .56

Figura 9 - Citoaderência dos sete isolados de campo em diferentes linhagens de CHO.......58

Figura 10 - Comparação do comportamento de adesão entre o primeiro diagnóstico e segundo diagnóstico de sete isolados de campo.

Figura 11 - Análise de citoaderência dos isolados de campo selecionados para CD36 e ICAM-1.

Figura 12 - Comparação do perfil de adesão inicial e pós-seleção.

Figura 13 - Citoaderência do isolado $\mathrm{FMS}^{\mathrm{CD} 36}$ e $\mathrm{FMS}^{\mathrm{ICAM}}$ em HLEC. .63

Figura 14 - Citoaderência do isolado $38 \mathrm{~A}^{\mathrm{CD} 36}$ em HLEC. 64

Figura 15 - Citoaderência do isolado $\mathrm{PfO}^{\mathrm{CD} 36}$ e PfO3 ${ }^{\text {ICAM }}$ em HLEC. .64

Figura 16 - Citoaderência em HLEC sob condições de fluxo. 66

Figura 17 - Experimentos de adesão e desprendimento em condições de fluxo de FMS ICAM.

Figura 18 - Experimentos de adesão e desprendimento em condições de fluxo de FMS ${ }^{\mathrm{CD} 36}$.

Figura 19 - Experimentos de adesão e desprendimento em condições de fluxo de $38 \mathrm{~A}^{\mathrm{CD} 36}$.

Figura 20 - Experimentos de adesão e desprendimento em condições de fluxo de 38A $\mathrm{A}^{\text {ICAM }}$.

Figura 21 - PCR em tempo real para detecção do gene kahrp. .......................................72

Figura 22 - Filme fotográfico do western blot das células $\mathrm{CHO}$.......................................74

Figura 23 - Citometria de fluxo das células CHO-ICAM1. .............................................75

Figura 24 - Citometria de fluxo das células CHO-CD36 pós-sorting . ...................................76

Figura 25 - Imunofluorescência das células CHO-ICAM1. ............................................77 
Figura 26-Imunofluorescência das células CHO-CD36 com maior concentração de anticorpo.

Figura 27 - Análise de correlação entre tempo de Amazônia e a capacidade de reconhecer diferentes antígenos.

Figura 28 - Análise de bloqueio de adesão em CHO-ICAM1. ............................................82

Figura 29 - Análise de bloqueio de adesão em CHO-CD36. ..................................................

Figura 30 - Análise de bloqueio de adesão em CD36 recombinante. ..................................83

Figura 31 - Citoaderência de $38 \mathrm{~A}^{\text {ICAM }}$ cultivado em meio com Albumax e em meio com plasma a células CHO-ICAM1. 


\section{LISTA DE TABELAS}

Tabela 1 - Manifestações e complicações da malária grave por Plasmodium falciparum.

Tabela 2 - Origem dos isolados de Plasmodium falciparum. ............................................35

Tabela 3 - Reprodução da montagem da microplaca Lab-Tek para o isolado $38 A^{\mathrm{CD} 36} \ldots . . . . .46$

Tabela 4 - Reprodução da montagem da microplaca Lab-Tek para o isolado FMS ${ }^{\mathrm{CD} 36}$.......46

Tabela 5 - Reprodução da montagem da microplaca Lab-Tek para o isolado 38A ${ }^{\text {ICAM1 }}$.......46

Tabela 6 - Reprodução da montagem da microplaca Lab-Tek para o isolado Pf03. ...........47

Tabela 7 - Oligonucleotídeos utilizados para a amplificação dos 10 marcadores microssatélites de DNA (MSAT) em amostras de $P$. falciparum. ..........................................51

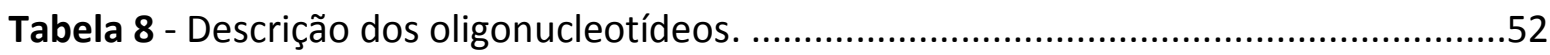

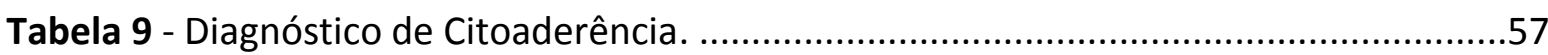

Tabela 10 - Descrição, localização e tamanho dos genes adjacentes ao $h r p 2$ e $h r p 3$. .........71

Tabela 11 - Resultados do exame de deleção dos genes hrp2 e hrp3 e seus genes adjacentes.

Tabela 12 - Valores e média do CT das triplicatas dos isolados de $P$. falciparum.

Tabela 13 - Porcentagem de amostras de soro que reconhecem cada isolado testado. .....79

Tabela 14 - Tabela de correlação entre idade, tempo de moradia na área de estudo e tempo de moradia na Amazônia com a intensidade de reconhecimento de cada isolado testado.

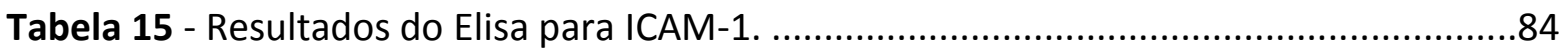

Tabela 16 - Indivíduos heterozigotos para hemoglobina S. ............................................85 


\section{LISTA DE ABREVIATURAS}

\begin{tabular}{|c|c|}
\hline ATS & Acidic terminal segment \\
\hline BSA & Bovine serum albumin \\
\hline C2 & Constant 2 \\
\hline CD36 & Cluster of differentiation 36 \\
\hline cDNA & DNA complementar \\
\hline CIDR & Cyisteine-rich interdomain region \\
\hline $\mathrm{CHO}$ & Células de Chinese Hamster Ovary \\
\hline CSA & Chondroitin sulfate $A$ \\
\hline Ct & Cycle Threshold \\
\hline DBL & Duffy binding like \\
\hline DNA & Ácido desoxirribonucléico \\
\hline EDTA & Ácido etilenodiaminotetracético \\
\hline ELISA & Enzyme Linked Immuno Sorbent Assay \\
\hline EP & Eritrócito(s) parasitado(s) \\
\hline FACS & Fluorescence Ativated Cell Sorted \\
\hline FCS & Soro fetal bovino (fetal calf serum) \\
\hline g & Aceleração da gravidade $\left(9,8 \mathrm{~m} / \mathrm{s}^{2}\right)$ \\
\hline gDNA & DNA genômico \\
\hline $\mathrm{HbC}$ & Hemoglobina C \\
\hline HbS & Hemoglobina S ou Anemia falciforme \\
\hline HLEC & Human lung endothelial cells \\
\hline INCRA & Instituto Nacional de Colonização e Reforma Agrária \\
\hline GPI & glicosilfosfatidilinositol \\
\hline HRP & Histidine Rich Protein \\
\hline ICAM-1 & Intercellular adhesion molecule 1 \\
\hline $\lg$ & Imunoglobulina \\
\hline KAHRP & Knob-associated histidine-rich protein \\
\hline $\mathrm{mA}$ & Miliampere \\
\hline MIF & Média da intensidade de fluorescência \\
\hline $\mathrm{Pa}$ & pascal \\
\hline pb & pares de base \\
\hline PBS & Phosphate-Buffered saline \\
\hline PCR & Reação em cadeia de polimerase (Polymerase Chain Reaction) \\
\hline PfEMP1 & Plasmodium falciparum erythrocyte membrane protein 1 \\
\hline qPCR & PCR quantitativo ou PCR em tempo real \\
\hline RDT & Testes de diagnóstico rápido \\
\hline RPMI & Roswell Park Memorial Institute (meio de cultivo) \\
\hline TA & Temperatura ambiente \\
\hline TAE & Tampão Tris-acetato \\
\hline TBE & Tampão Tris-borato \\
\hline TE & Tampão Tris-EDTA \\
\hline TM & Transmembrana \\
\hline TNF & Tumoral necrosis factor \\
\hline TSP & Trombospondina \\
\hline
\end{tabular}


Ups

V

VSA

WHO
Upstream

Volts

Variant surface antigens

World Health Organization 


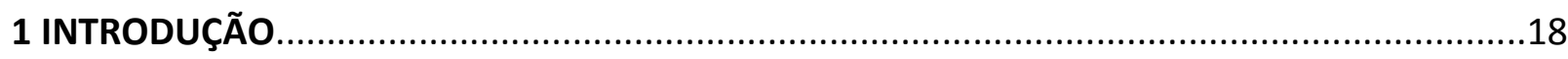

1.1 Malária como problema de saúde pública..................................................................19

1.2 Malária grave e aderência do parasita ao endotélio vascular..........................................20

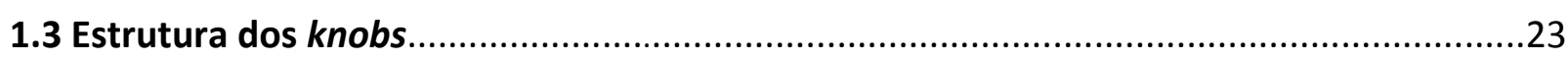

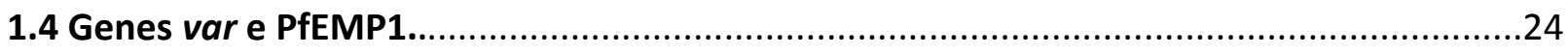

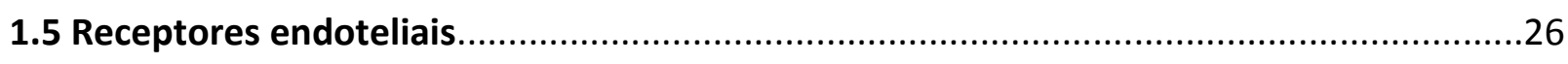

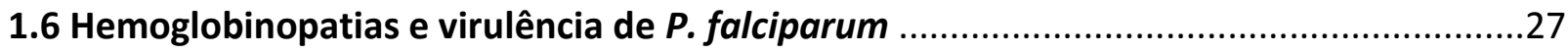

1.7 Anticorpos anti-VSAs com propriedades adesivas conhecidas ...................................28

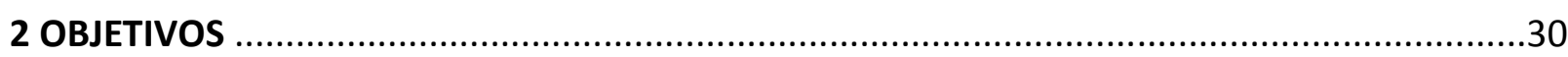

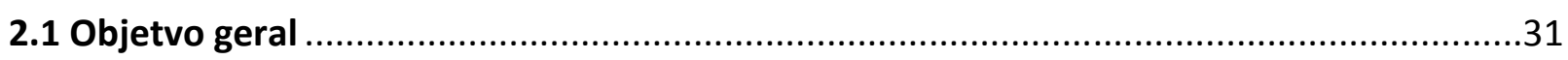

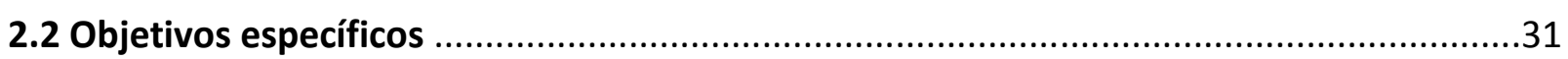

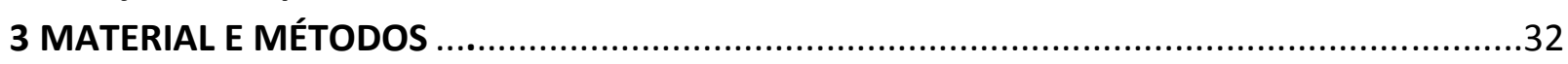

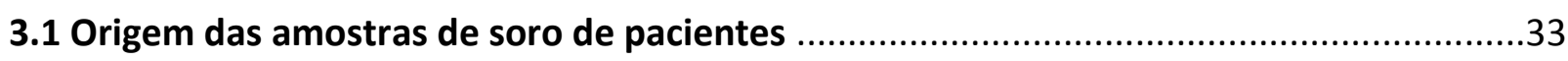

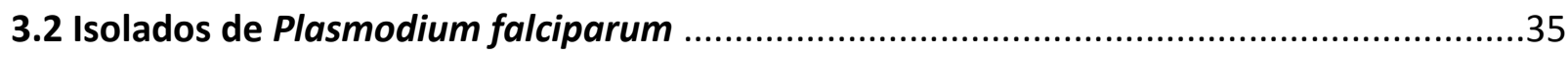

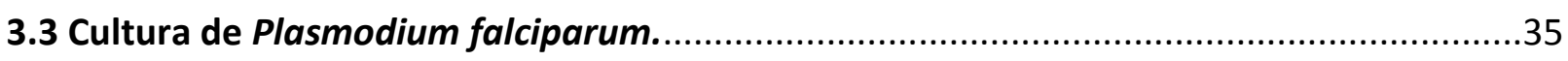

3.4 Congelamento e descongelamento dos isolados de campo ........................................36

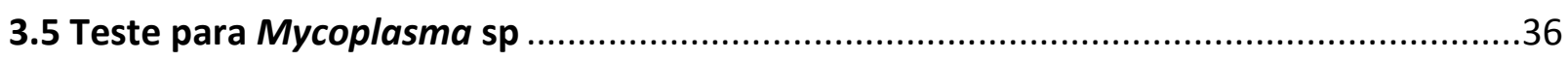

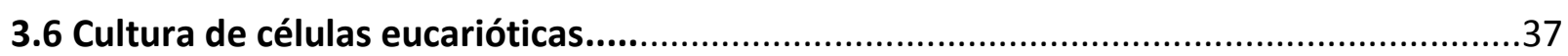

3.7 Preparação dos parasitas para o ensaio de citoaderência em CHO e HLEC ......................38

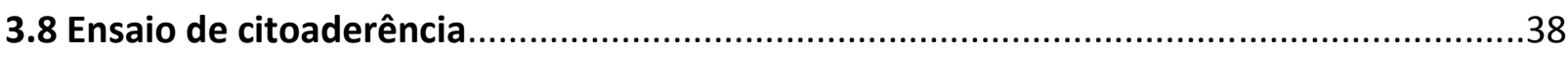

3.8.1 Avaliação da capacidade de citoaderência dos isolados em estudo utilizando CHO.....38

3.8.2 Avaliação da capacidade de citoaderência dos isolados em estudo utilizando HLEC....39

3.8.3 Seleção dos isolados para fenótipos aderentes a CD36 e a ICAM-1 através da

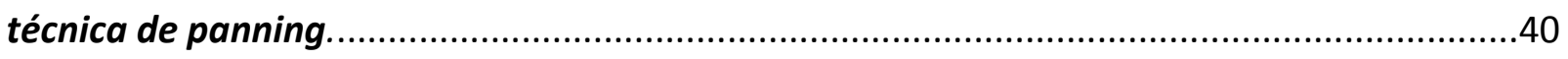

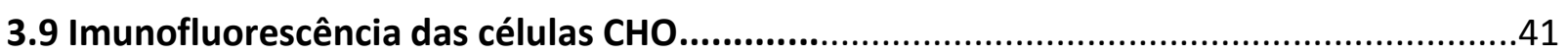

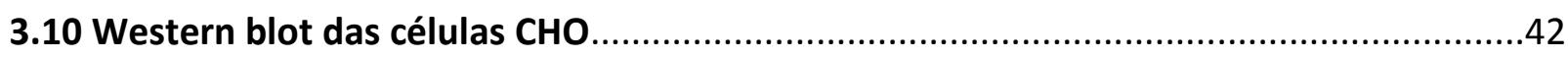

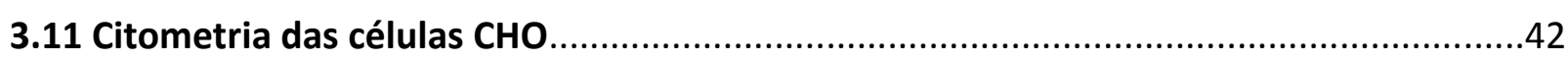

3.12 Citometria de fluxo para avaliar reconhecimento por anticorpos................................43

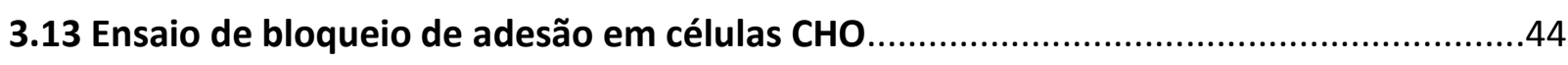

3.14 Ensaio de bloqueio de adesão em CD36 e ICAM-1 recombinantes..............................47

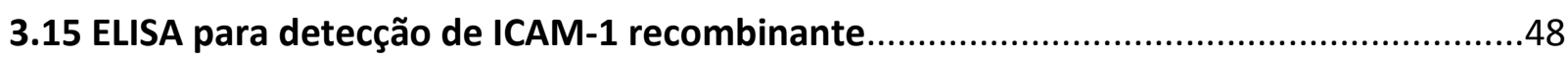

3.16 Extração de DNA para análise de microssatélites e deteç̧ão dos genes pfhrp2 e

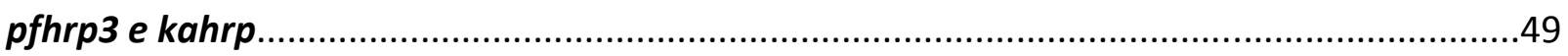

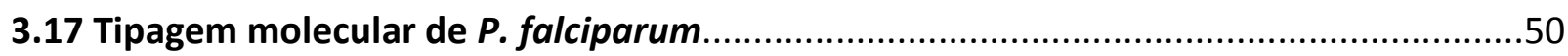

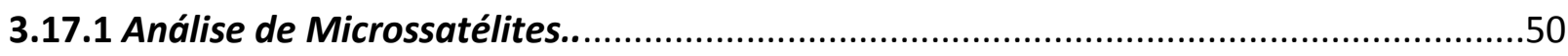

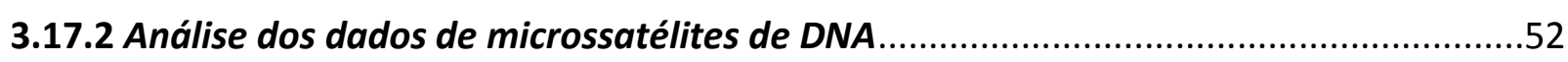

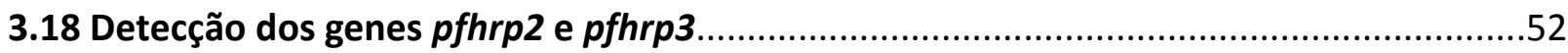

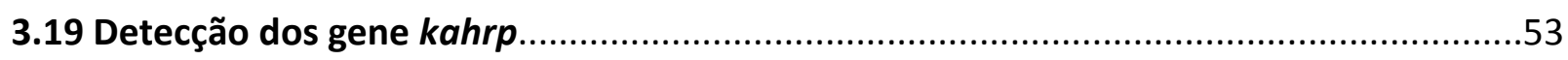

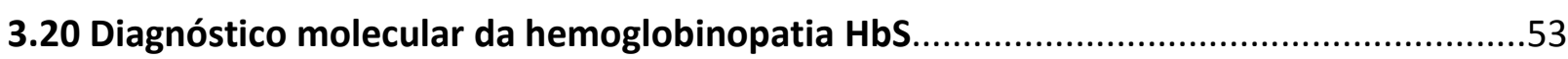




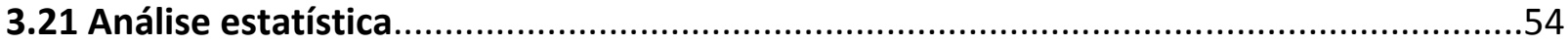

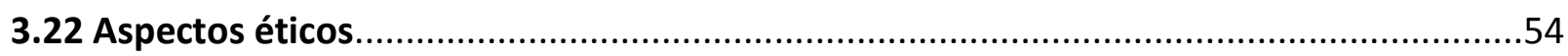

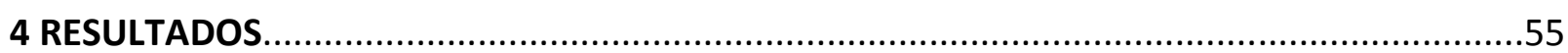

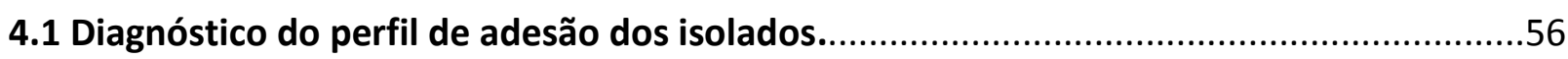

4.2 Citoaderência a HLEC em condições estáticas.................................................................63

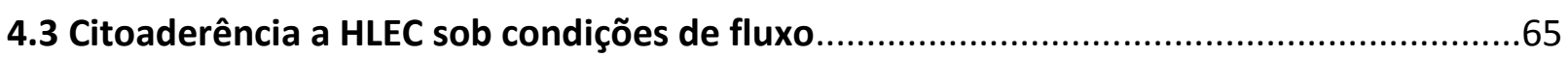

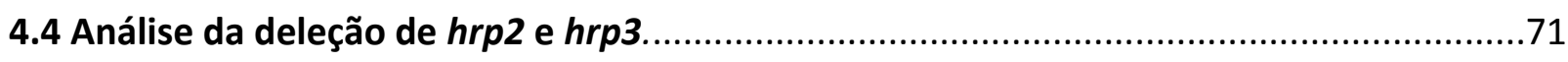

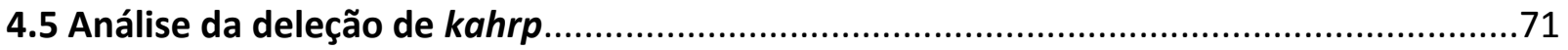

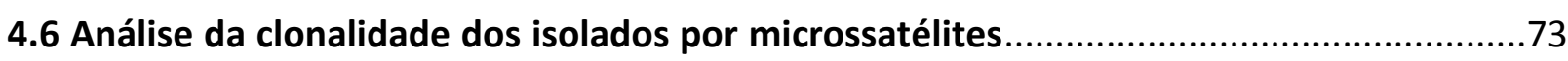

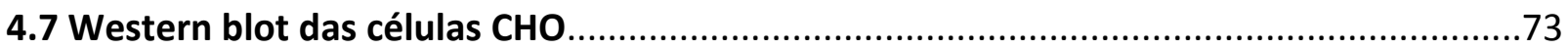

4.8 Expressão de CD36 e ICAM-1 por citometria de fluxo.....................................................74

4.9 Análise da expressão de CD36 e ICAM-1 nas células CHO por imunofluorescência...........77

4.10 Análise de reconhecimento de anticorpos por Citometria de Fluxo................................79

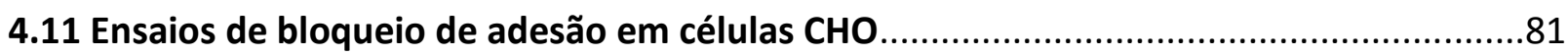

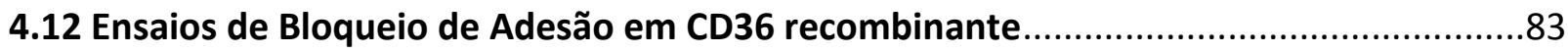

4.13 Ensaios de Bloqueio de Adesão em ICAM-1 recombinante.........................................84

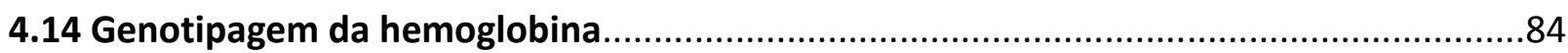

4.15 Análise do potencial de adesão do isolado $38 A^{\text {ICAM }}$ cultivado em meio suplementado

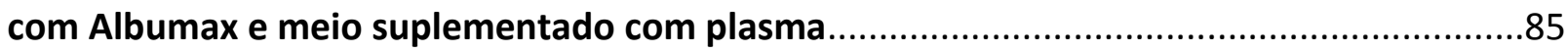

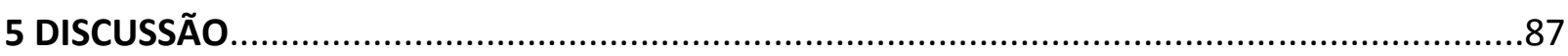

5.1 Aderência de isolados de $\boldsymbol{P}$. falciparum da Amazônia brasileira a CD36 e ICAM-1..........88

5.2 Reconhecimento de anticorpos de indivíduos naturalmente expostos à malária na Amazônia brasileira a VSAs locais capazes de mediar aderência a CD36 e ICAM-1...............91

5.3 Capacidade dos anticorpos de indivíduos naturalmente expostos à malária na Amazônia brasileira de bloquearem a aderência de isolados locais a CD36 e ICAM-1.........................94

5.4 Hemoglobinopatia e perfil de aderência de isolados locais..........................................94

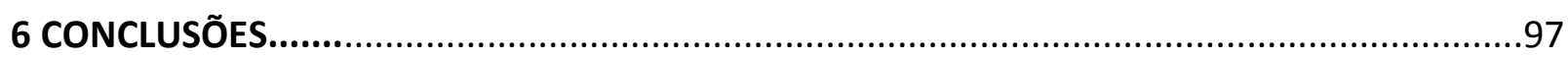

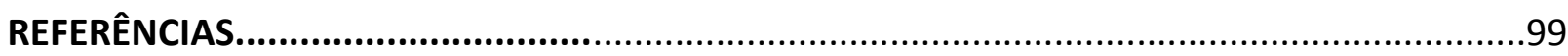


1 INTRODUÇÃO 


\subsection{Malária como problema de saúde pública}

Apesar do sucesso da erradicação da malária em diversos países, metade da população mundial habita áreas de risco de malária, estimando-se que aproximadamente 3,3 bilhões de pessoas estejam expostas ao Plasmodium em todo mundo (World Health Organization, 2011). Em 2010, a Organização Mundial da Saúde estimou em cerca de 250 milhões o número de casos de malária no mundo, dos quais $85 \%$ ocorreram na Região Africana, $10 \%$ no Sudeste Asiático e $4 \%$ nas regiões do Mediterrâneo Oriental (WHO, 2010). Dos 250 milhões, 91\% dos casos foram causados por P. falciparum, atingindo principalmente crianças menores de cinco anos de idade e mulheres grávidas.

Atualmente, há 106 países sob o risco de contrair a malária, a maioria deles localizados no continente africano (Figura 1) (WHO, 2011). Trinta e cinco países concentram a maioria dos óbitos, dentre os quais, somente cinco são responsáveis por 47\% dos casos de malária e 50\% das mortes em todo o mundo, são eles: Nigéria, República Democrática do Congo, Uganda, Etiópia e Tanzânia (Roll Back Malaria, 2008).

Figura 1 - Distribuição mundial da malária em 2010.

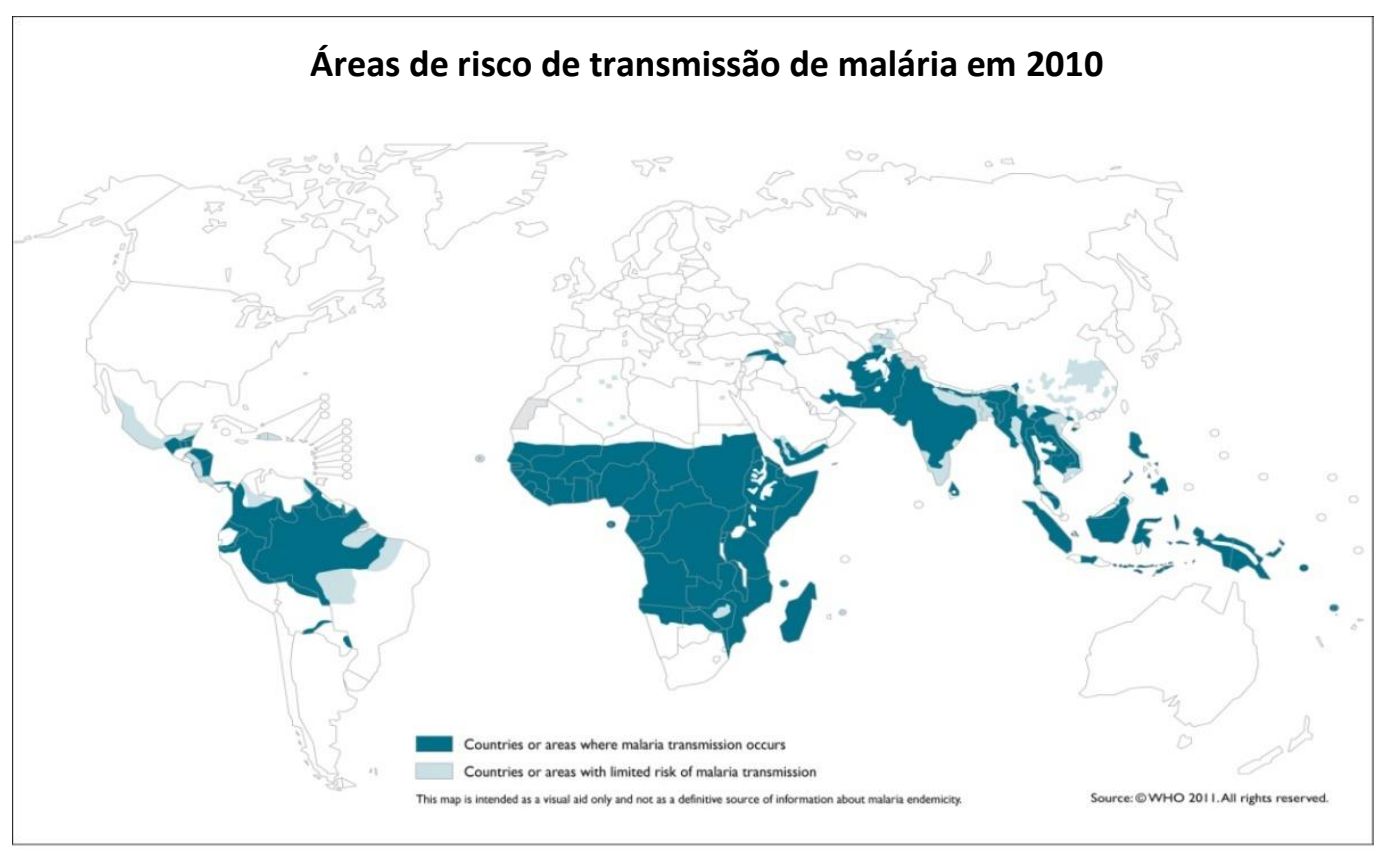

Fonte: Adaptado de WHO, 2011. 
No Brasil, a malária permanece entre as principais endemias parasitárias brasileiras com mais de 99\% dos casos adquiridos na Amazônia Legal (Pan American Health Organization, 2008), sendo aproximadamente $20 \%$ desses casos ocasionados por Plasmodium falciparum, espécie que mais frequentemente produz doença grave. No entanto, a letalidade da malária permanece em patamares baixos no Brasil, em torno de 0,023\% (Datasus, 2006).

\subsection{Malária grave e aderência do parasita ao endotélio vascular}

Embora a epidemiologia da malária grave permaneça virtualmente inexplorada no Brasil, pacientes com quadros de malária grave são raramente observados em áreas endêmicas. Por exemplo, em uma série de 175 episódios de infecção por $P$. falciparum confirmados por microscopia ou reação em cadeia da polimerase (PCR) em população rural do Acre (da Silva-Nunes, Ferreira, 2007), observaram-se somente três hospitalizações, sem casos que preenchessem os critérios de definição de malária grave e complicada da Organização Mundial da Saúde (Warrell et al., 1992) relacionados na Tabela 1.

São particularmente raros no Brasil os episódios de malária cerebral, que tipicamente acomete crianças africanas e indivíduos de todas as idades no Sudeste Asiático. A definição de malária cerebral restringe-se aos pacientes com malária falciparum em coma profundo, incapazes de localizar estímulos dolorosos, nos quais outras encefalopatias (infecciosas e metabólicas) tenham sido excluídas. No Brasil, a maior parte dos pacientes com malária grave apresenta, à admissão ou durante a evolução, um quadro complexo de comprometimento de múltiplos órgãos em que o coma, se presente, é um componente adicional (Ferreira et al., 1998).

O principal fator de virulência de $P$. falciparum é a capacidade de aderência das hemácias parasitadas por estágios maduros do parasita ao endotélio de pequenos vasos sanguíneos, particularmente de vênulas pós-capilares (Wahlgren et al., 1999). Os eritrócitos parasitados pelos estágios maduros desaparecem da circulação periférica, permanecendo sequestrados nos vasos de diversos órgãos, incluindo o coração, o pulmão, o intestino delgado e o cérebro (Pongponratn et al., 1991). 
Tabela 1- Manifestações e complicações da malária grave por Plasmodium falciparum

Malária cerebral

Coma profundo na ausência de outra encefalopatia infecciosa ou metabólica.

Convulsões generalizadas

Mais de duas crises convulsivas em 24 horas.

Anemia grave

Concentração de glicose sanguínea abaixo de $5 \mathrm{~g} / 100 \mathrm{ml}$ ou hematócrito inferiror a 15\% geralmente requerem hemotransfusão.

Hipoglicemia

Concentração de glicose sanguínea inferior a 40 mg/100 ml.

Insuficiência renal aguda

Concentração de creatinina plasmática superior a $3 \mathrm{mg} / 100 \mathrm{ml}$ com débito urinário inferior a $400 \mathrm{ml} \mathrm{em} 24 \mathrm{~h} \mathrm{(12} \mathrm{ml/kg/dia} \mathrm{em} \mathrm{crianças).}$

Edema pulmonar e síndrome da angústia respiratória do adulto

Se possível, com comprovação radiológica do edema pulmonar e monitoramento de pressão capilar ou venosa central.

Choque circulatório ("malária álgida")

Acidose metabólica

Níveis sanguíneos de bicarbonato abaixo de $15 \mathrm{mmol} / \mathrm{L}$ e pH sanguíneo abaixo de 7,35.

Alterações de hemostasia

Hemorragias retinianas e gengivais, trombocitopenia.

Hemólise intravascular maciça ou febre hemoglobinúrica ("blackwater fever")

Hipertermia

Hiperparasitemia

Parasitemia acima de 100.000 parasitas por milímetro de sangue.

Disfunção hepática e icterícia

Ruptura esplênica

Reproduzido de Ferreira, da Silva Nunes (2009).

A aderência das hemácias infectadas ao endotélio pode causar a obstrução de pequenos vasos, com consequente hipóxia tecidual. Simultaneamente, moléculas do parasita liberadas ao final da esquizogonia eritrocitária, como o GPI (glicosilfosfatidilinositol), podem estimular a produção de citocinas pró-inflamatórias. A expressão, pelo endotélio vascular, de alguns receptores envolvidos na adesão de hemácias parasitadas, como ICAM-1 e selectina-E, é estimulada por citocinas pró- 
inflamatórias como o fator de necrose tumoral (TNF- $\alpha$ ), produzido por macrófagos e monócitos. A maioria das complicações clínicas que caracterizam a malária grave por $P$. falciparum é consequência direta ou indireta da aderência de hemácias parasitadas ao endotélio vascular e, possivelmente, da formação de rosetas (aglomerados de hemácias parasitadas em torno de hemácias não-parasitadas), que induzem diversas alterações inflamatórias e metabólicas (Ferreira, da Silva-Nunes, 2009; de van der Heyde et al., 2006) (Figura 2).

Figura 2 - Fisiopatologia da malária grave e complicada por Plasmodium falciparum.

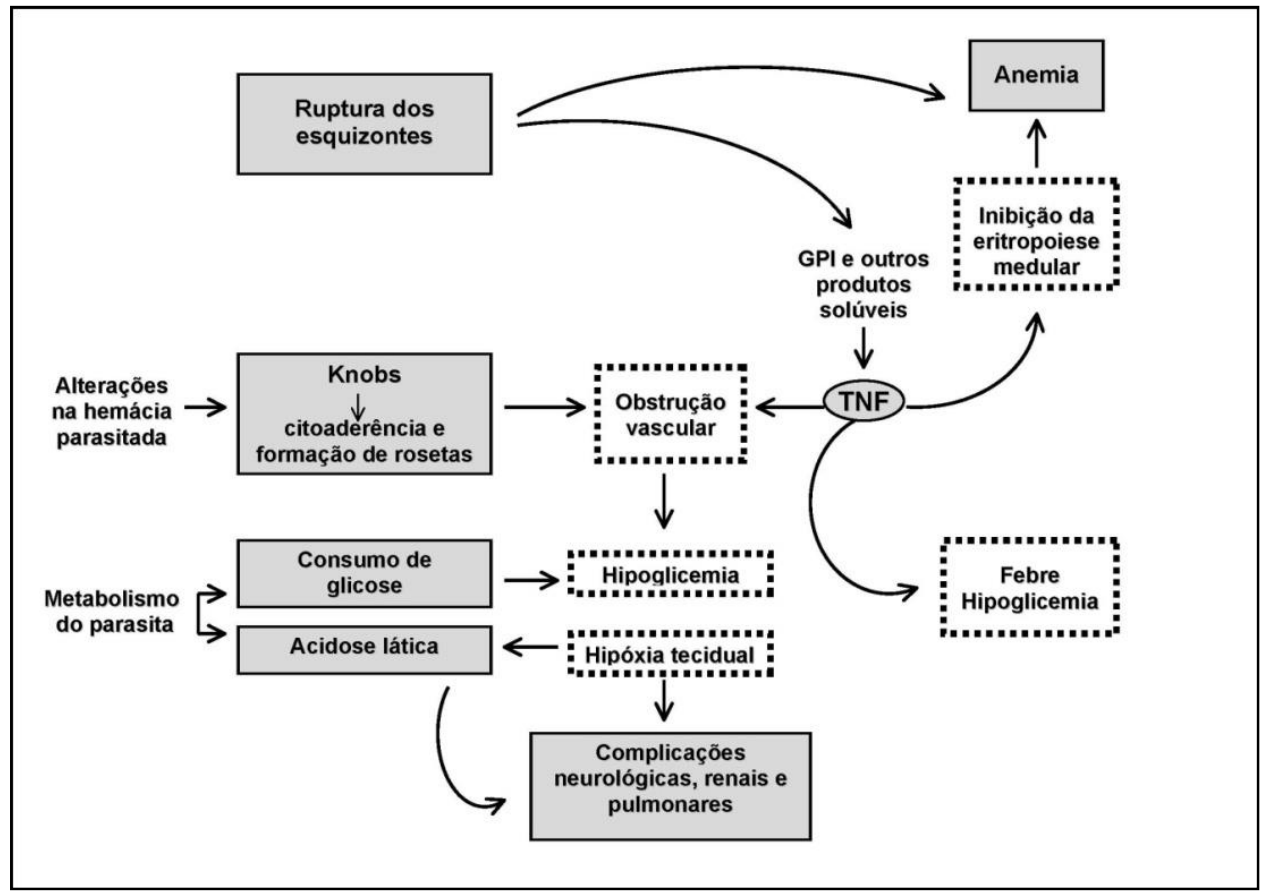

O evento central é a aderência das hemácias infectadas ao endotélio de pequenos vasos (especialmente vênulas pós-capilares) e a hemácias não-infectadas (formando rosetas). A produção de citocinas próinflamatórias por células do hospedeiro, como o fator de necrose tumoral (TNF), é estimulada por produtos solúveis (particularmente glicosilfosfatidilinositol ou GPI) liberados pelo parasita ao final da esquizogonia sanguínea. Os níveis elevados de TNF induzem a expressão de alguns receptores endoteliais como ICAM-1 e selectina-E, promovendo a citoaderência, e estão associados à febre, à hipoglicemia e à anemia. Por outro lado, o próprio metabolismo do parasita sequestrado nos pequenos vasos contribui para a hipoglicemia e a acidose. A obstrução microvascular, combinada a alterações inflamatórias e metabólicas, pode explicar o acometimento de diversos órgãos e sistemas observado na malária grave. Fonte: Reproduzido de Ferreira, da Silva-Nunes (2009). 


\subsection{Estrutura dos knobs}

A citoaderência está relacionada com a formação de protuberâncias na superfície das hemácias parasitadas, conhecidas como knobs, durante os estágios de trofozoítos maduros e esquizontes sanguíneos de P. falciparum (Aikawa, 1988; Kilejian, 1979). As proteínas do parasita presentes na superfície dos knobs são coletivamente conhecidas como antígenos variantes de superfície de hemácias infectadas, referidos na literatura de língua inglesa como variant surface antigens ou VSA. Em 1984, Leech e colaboradores mostraram que o principal VSA é a PfEMP-1 (proteína da membrana do eritrócito 1), codificada pela família de genes var (Smith et al., 1995).

Entre os demais constituintes dos knobs estão as proteínas da família das Histidine Rich Protein (KAHRP, HRP2, HRP3 e MaHRP). Knob-associated histidine-rich protein (KAHRP) é uma proteína considerada de extrema importância para a formação do knob em eritrócitos infectados (Figura 3), interagindo com proteínas do citoesqueleto do eritrócito e também com PfEMP1 (Waller et al., 1999). A KAHRP parece estar envolvida na localização da PfEMP1, de modo que a sua ausência na membrana do eritrócito leva a um enfraquecimento da interação entre PfEMP1 e o endotélio vascular (Crabb et al., 1997). No entanto, a ausência do knob ou da KAHRP parece não prejudicar o transporte de PfEMP1 para a superfície do eritrócito (Rug et al., 2006).

A estrutura primária da KAHRP é constituída de três domínios, entre os quais, a região 3 (C-terminal) apresenta grande polimorfismo, com importantes implicações em estudos que visam esta proteína como alvo de terapia anti-adesão, como estratégia alternativa de controle à malária (Mardani et al., 2011).

As HRPs também são importantes nos testes de diagnóstico rápido (RDT). Esses testes utilizam anticorpos que se ligam a proteínas específicas de uma ou de todas as espécies de Plasmodium humano. RDTs baseadas na detecção de PfHRP2 representam a maioria dos RDTs disponíveis no mercado (mais de 80\%). A sensibilidade de detecção da PfHRP2 é afetada pelo número e composição das repetições dos aminoácidos da HRP2, uma vez que se trata de uma proteína constituída de uma região repetida rica em alaninahistidina e é liberada como uma proteína solúvel no sangue do indivíduo infectado (Baker et al., 2005; Gamboa et al., 2010; Manning et al., 2011). 
Figura 3 - Representação das moléculas envolvidas na adesão de hemácias infectadas por Plasmodium falciparum ao endotélio vascular.

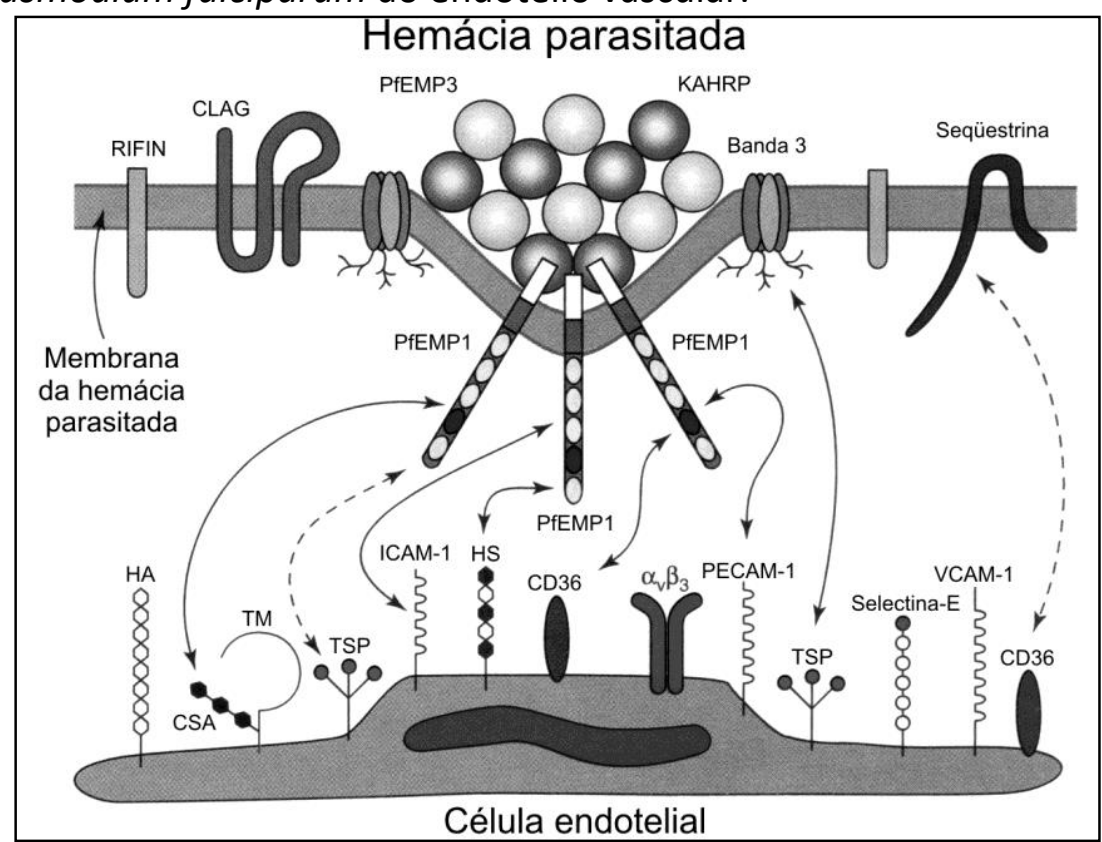

São representados antígenos de membrana da hemácia infectada (PfEMP-1, Rifin, Clag, sequestrina e banda 3 modificada) e receptores expressos pelas células endoteliais (CD36, ICAM-1, PECAM-1, trombospondina [TSP], selectina-E, sulfato de condroitina-A [CSA], ácido hialurônico [HA]. Fonte: Adaptado de Cooke et al., 2000.

\subsection{Genes var e PfEMP1}

Cada genoma de $P$. falciparum contém aproximadamente 60 genes var distintos espalhados pelos 14 cromossomos e localizados principalmente nas regiões subteloméricas. O controle da transcrição desse genes é regulado através de um mecanismo mutuamente exclusivo, que deixa somente uma ou algumas poucas cópias de genes var transcricionalmente ativas de cada genoma. Portanto, o parasita expressa uma única versão de PfEMP-1 na superfície da hemácia. (Chen et al. 1998; Scherf et al. 1998).

Os genes var são subdivididos nos grupos upsA, upsB, upsC e upsE, baseado na localização cromossômica e na sequência da região 5' promotora upstream (Ups) (Kraemer, Smith, 2006; Lavstsen et al., 2003). Embora as proteínas sejam bastante variáveis, os promotores dos genes var são bastante conservados.

As proteínas PfEMP1 são codificadas por dois exons, que irão constituir uma porção extracelular altamente variável, formada pelos domínios DBL, CIDR e C2 (constant 2), que medeiam a aderência a receptores do endotélio vascular, uma pequena região TM 
(transmembrana) e uma porção intracelular (C-terminal) formada pelo domínio citoplasmático ATS, mais conservado (Figura 4). Este último domínio interage com a KAHRP dentro dos knobs (Kraemer, Smith, 2003). Além disso, proteínas PfEMP1 apresentam em sua estrutura um domínio terminal N-terminal (NTS) que contêm um motivo conservado chamado PEXEL (Plasmodium export element), indicando que essa proteína é exportada para a membrana do eritrócito (Marti et al., 2005).

Recentemente, e após reclassificação de domínios de PfEMP1 a partir de análise de 7 genomas sequenciados (Rask et al., 2010), foi visto que uma classe de PfEMP1 possui grande associação com a malaria cerebral. No genoma do parasita 3D7 esta PfEMP1 é codificada pelo gene var PFD0020c (Claessens et al., 2012). Independentemente, o mesmo tipo de gene var transcrito foi encontrado em amostras de campo (Lavstsen et al., 2012).

Figura 4 - Representação esquemática da estrutura de PfEMP-1 na superfície da hemácia infectada.

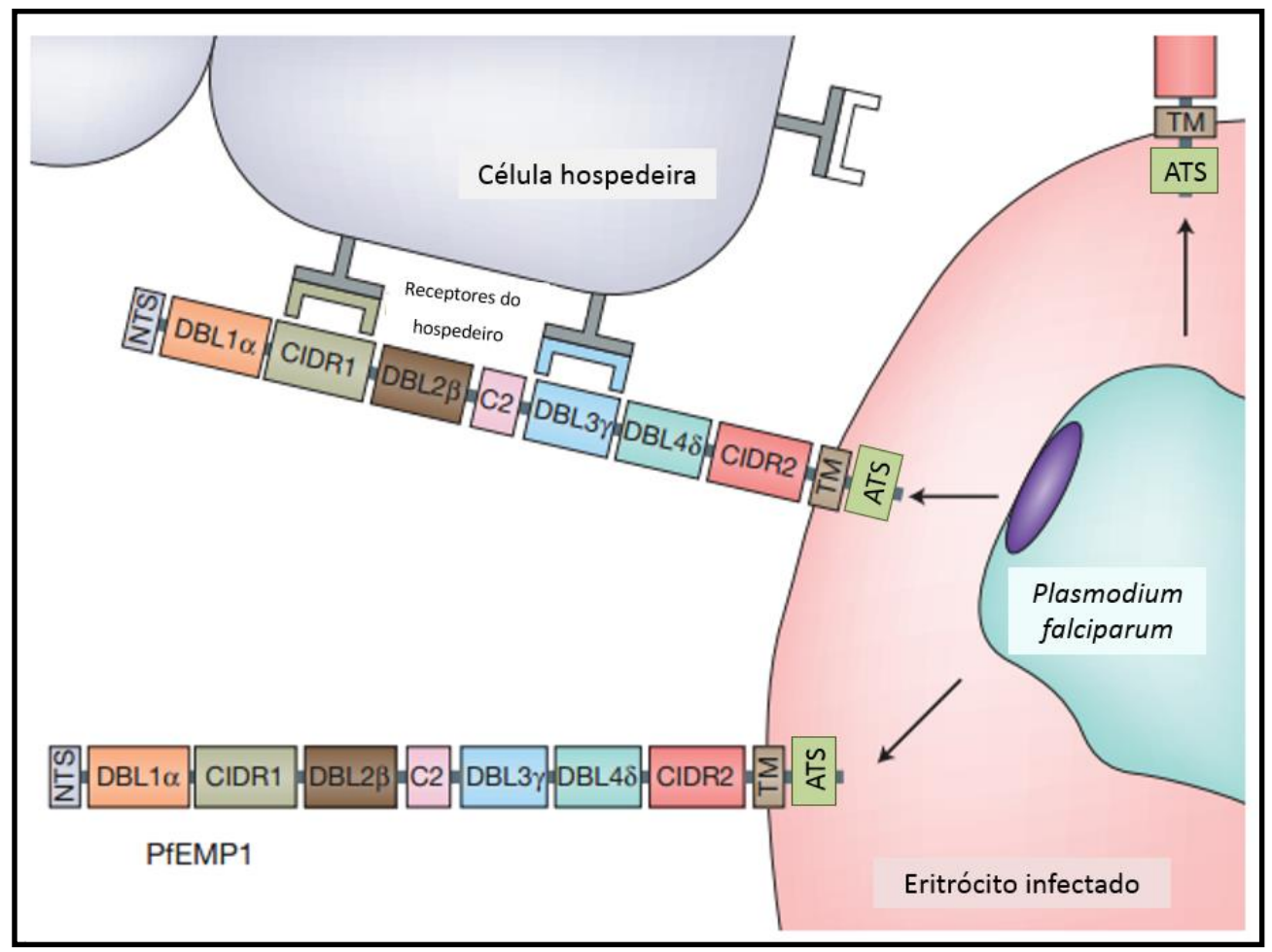

Estrutura de PfEMP-1, o principal componente dos knobs presentes na membrana da hemácia infectada. São representados o domínio intracelular (acidic terminal segment, ATS), que ancora PfEMP-1 à superfície da hemácia, bem como a região extracelular da molécula, que compreende quatro tipos de domínios: NTS (N-terminal segment), DBLs (Duffy binding-like domains), CIDRs (cystein-rich interdomain regions) e C2 (constant 2). TM corresponde ao domínio transmembrana. Fonte: Adaptado de Rowe et al., 2009. 


\subsection{Receptores endoteliais}

A PfEMP1 é de extrema importância para a sobrevivência e crescimento do parasita dentro do hospedeiro (Fonager et al., 2012) e pode ligar-se a diversos receptores presentes no endotélio vascular, tais como moléculas sulfatadas (sulfato de condroitina $A$ [CSA], sulfato de heparana), CD36 e receptores como ICAM-1, VCAM-1 e PECAM-1/CD31, entre outras (Figura 3).

CD36, uma glicoproteína integral de membrana na forma de monômero, está presente na superfície de monócitos, plaquetas, células dendríticas, células endoteliais e uma ampla variedade de linhagens de células cultivadas. Trata-se de um receptor amplamente distribuído no endotélio vascular de vários órgãos. O papel fisiológico de CD36 é de receptor "scavenger" e possui capacidade de ligar trombospondina, colágeno, LDL oxidado e outros ácidos graxos. CD36 parece interagir com CIDR (Figura 4), domínio bastante polimórfico, mas presente em todas as variantes de PfEMP-1, e ainda pode estar presente em uma ou duas cópias em cada variante dessa proteína (Baruch et al., 2002).

Os genes var pertencentes aos grupos B e C codificam variantes PfEMP1 que se ligam a CD36, que sendo um receptor endotelial de distribuição mais ampla em diferentes órgãos, torna-se difícil associar a aderência a CD36 a complicações específicas observadas na malária grave (Baruch et al., 1997; Claessens et al., 2012). Por outro lado, ICAM-1 (molécula de adesão intercelular-1) foi considerado um dos principais receptores endoteliais envolvidos na malária grave, especialmente na malária cerebral (Berendt et al., 1989; Ochola et al., 2011). Trata-se de glicoproteína presente na superfície de linfócitos, monócitos, macrófagos e no endotélio vascular, sendo particularmente abundante no endotélio dos vasos sanguíneos cerebrais (van de Stolpe, van der Saag, 1996). O papel fisiológico de ICAM-1 é de receptor de integrina, assim funcionado como homing receptor para leucócitos. Ela também é utilizada por Rhinovirus como porta de entrada em células. Na presença de IL1 ou TNF $\alpha$, a expressão de ICAM-1 é aumentada. PfEMP-1 parece ligar-se a ICAM-1 através de um dos domínios DBL, conhecido como DBL$2 \beta$ seguido de domínio C2 (Baruch et al., 2002; Oleinikov et al., 2009). Embora se saiba que genes var do grupo $A$, que codificam variantes não aderentes a CD36, estejam relacionados à malária grave e inclusive à malária cerebral (Jensen et al., 2004), é extremamente difícil identificar os domínios responsáveis pelos fenótipos de adesão em 
cada variante observada na natureza devido a extraordinária complexidade e diversidade estrutural da PfEMP-1 (Baruch et al., 2002). É possível que outros domínios de PfEMP-1 estejam envolvidos na adesão a CD36 e ICAM-1, dependendo do arranjo em que eles aparecem em diferentes variantes de PfEMP-1, ou até que eles possam apresentar uma sinergia na interação com a hemácia parasitada (McCormick et al., 1997).

Neste trabalho, ao selecionar VSAs com afinidade por CD36 e ICAM-1 não pressupomos a existência de um arranjo particular de domínios de PfEMP-1 subjacente ao fenótipo observado.

\subsection{Hemoglobinopatias e virulência de $P$. falciparum}

A principal questão que envolve este projeto baseia-se na quase inexistência de casos de malária grave, particularmente de malária cerebral no Brasil. Uma das hipóteses seria a menor virulência dos isolados locais de $P$. falciparum, que expressariam VSAs com baixa adesividade quando comparados com isolados de origem africana ou asiática. Isso

decorreria devido à presença de hemoglobinopatias humanas na África, como um importante fator de seleção ligado ao hospedeiro (Fairhurst et al., 2005).

Mostrou-se que as hemácias com hemoglobina $\mathrm{C}(\mathrm{HbC})$ e a anemia falciforme (HbS) afetam a expressão de VSAs na superfície das hemácias não permitindo a formação adequada de knobs em sua superfície (Cholera et al., 2008; Fairhurst et al., 2005). A HbC causa um distúrbio hemolítico de intensidade variável, sendo comum em povos de origem africana (frequência alélica entre $15 \%$ e $30 \%$ ), mas sua frequência é muito variável na população brasileira (Bonini-Domingues et al., 2003). Já a frequência do alelo $S$ chega a $40 \%$ em algumas regiões da África e no Brasil, só é comum em populações de origem africana, especialmente no Sudeste e Nordeste (Silva et al., 2006; Sonati, Costa, 2008). Nas populações asiáticas, em que essas hemoglobinopatias inexistem e a malária grave é comum, há elevada prevalência de hemoglobina $E$, que aparentemente tem o mesmo efeito deletério sobre o transporte e a expressão de VSAs na superfície da hemácia (Rick Fairhurst, comunicação pessoal, 2008).

Portanto, para usufruírem os benefícios da citoaderência nessas populações, os parasitas teriam selecionado fenótipos de alta adesividade. Quando infectam indivíduos 
com hemoglobinopatias, esses parasitas manteriam certa capacidade de citoaderência, mesmo em condições adversas, mas sem chegar a níveis que levem à malária grave. Os quadros de malária grave ocorreriam quando os parasitas de alta aderência infectam indivíduos sem hemoglobinopatias e não-imunes (crianças pequenas, por exemplo), que ainda não produzem anticorpos anti-VSA capazes de bloquear, pelo menos em parte, sua adesão aos receptores endoteliais (Bull, Marsh, 2002; Giha et al., 2000).

Outras variações também descritas na África, referentes a uma mutação no gene de ICAM-1, assim como na sua região $5^{\prime}$ não traduzida, aumentaria o risco de malária cerebral, porém outros trabalhos contestam essa associação (Craig et al., 2000; CsertiGazdewich et al., 2010; Fry et al., 2008).

\subsection{Anticorpos anti-VSAs com propriedades adesivas conhecidas}

A mortalidade por malária na África concentra-se nos primeiros anos de vida do indivíduo, sugerindo que a aquisição gradual de imunidade contra o extenso repertório de VSAs dos parasitas locais reduziria o risco de malária grave (Bull et al., 2002). Estudos clássicos mostram associação entre a aquisição de anticorpos contra o repertório de VSAs de parasitas locais e a proteção contra as formas clínicas mais graves da malária (Bull et al., 2002). Entretanto, permanece inexplorada a aquisição de anticorpos contra VSAs com propriedades adesivas específicas, que teoricamente confeririam proteção contra certas complicações associadas à malária falciparum. Por exemplo, pode-se supor que a presença de anticorpos contra VSAs com afinidade por ICAM-1, expressas pelos parasitas locais, reduziriam o risco de malária cerebral, mas essa hipótese não foi testada em estudos prospectivos de base populacional.

Determinar a prevalência de anticorpos contra VSAs com propriedades adesivas específicas permite não apenas inferir os níveis de proteção contra manifestações clínicas da malária grave. No caso de uma aquisição de anticorpos ao longo das infecções, permite também estimar com que frequência indivíduos residentes em diferentes áreas endêmicas são expostos a VSAs com certas propriedades adesivas e, por conseguinte, estimar se os parasitas locais expressam frequentemente VSAs com essas propriedades. Recentemente, um estudo em ambiente de alta transmissão (Quênia) mostrou que a resposta, de fato, parece ser principalmente direcionada contra PfEMP1 (Chan et al., 
2012) reiterando a importância do investimento na pesquisa da resposta numa situação epidemiologicamente diferente, uma vez que poucos fenótipos estão associados à malária grave, o que favorece a aquisição de imunidade em áreas de alta transmissão (Claessens et al., 2012; Lavstsen et al., 2012). 
2 OBJETIVOS 


\subsection{Objetivo geral}

Este trabalho tem como objetivo analisar a capacidade de adesão a receptores endoteliais (CD36 e ICAM-1) de isolados de P. falciparum de uma área da Amazônia brasileira em que a malária grave é rara, bem como analisar a resposta de anticorpos de indivíduos locais contra os antígenos variantes de superfície potencialmente associados a esses fenótipos de adesão, pressupondo que ICAM-1 seja expresso em casos de malária cerebral como mostrado anteriormente (Berendt et al., 1989; Ochola et al., 2011).

\subsection{Objetivos específicos}

1. Verificar se isolados de $P$. falciparum colhidos em uma área endêmica rural do estado do Acre apresentam variantes de VSA capazes de aderir a ICAM-1 e CD36 e selecionar parasitas com esses fenótipos de adesão.

2. Determinar, com métodos moleculares, a frequência do alelo $S$ (hemoglobina $S$ ) na população rural de estudo, para verificar se essas hemoglobinopatias são substancialmente mais raras aqui do que em populações africanas.

3. Verificar se a capacidade de aderência dos isolados de campo está associada à presença/deleção dos genes que expressam as proteínas HRP2, HRP3 e KAHRP de Plasmodium falciparum.

4. Determinar a prevalência, em uma população rural continuamente exposta à malária na zona rural do Acre, de anticorpos contra variantes locais de VSA capazes de aderir a ICAM-1 e CD36, bem como a VSAs de parasitas locais não sujeitos ao processo de seleção para fenótipos específicos de adesão. Com base nesses dados, estimar a frequência com que os parasitas locais expressam variantes de VSA capazes de aderir a ICAM-1 e CD36.

5. Analisar se os anticorpos naturalmente adquiridos que reconhecem VSAs capazes de aderir a ICAM-1 e CD36 bloqueiam a adesão de hemácias parasitadas a esses receptores. 
3 MATERIAL E MÉTODOS 


\subsection{Origem das amostras de soro de pacientes}

As amostras de soro e DNA humano disponíveis para o estudo, colhidas em março-abril de 2004, provêm de 500 indivíduos (entre 5 e 90 anos de ambos os sexos que apresentavam ou não sintomas de malária) de uma área de assentamento agrícola conhecida como Ramal do Granada, localizada no extremo leste do estado do Acre, Amazônia Ocidental brasileira, a 30-45 km da zona urbana do município de Acrelândia. Essa população foi cuidadosamente caracterizada quanto a fatores demográficos, socioeconômicos, ambientais, genéticos e imunológicos associados ao risco de malária e à sua expressão clínica (Bastos et al., 2007; da Silva-Nunes, Ferreira, 2007; da Silva-Nunes et al., 2008; Scopel et al., 2007).

A área de estudo compreende as localidades rurais conhecidas como Linha 14 Gleba Q e Reserva da Linha 14, definidas pela Coordenação de Controle de Endemias da SESACRE, e coletivamente designadas como Ramal do Granada, denominação adotada pela população local para referir-se à Linha 14 (Figura 5).

Figura 5 - Localização do Ramal do Granada.

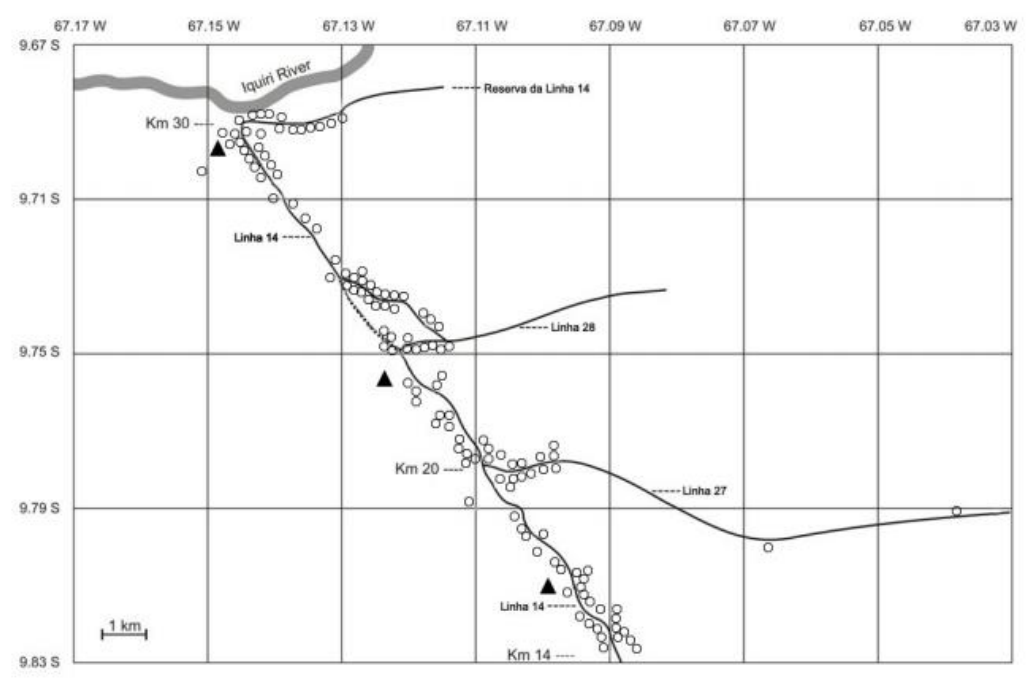

Domicílios (círculos) pertencentes ao Ramal do Granada que participaram do estudo, e dos postos governamentais de diagnóstico de malária (triângulos). Fonte: da Silva, 2011. 
A distribuição dos ramais segue uma ordem cronológica de ocupação da área, sendo os assentamentos mais antigos aqueles localizados nos primeiros $10 \mathrm{~km}$ da área, ocupados por famílias com maior poder aquisitivo do que aquelas localizadas entre o $\mathrm{km}$ 24 e a Reserva da Linha 14. Não apenas o fator socioeconômico está relacionado à posse da terra, mas também a porcentagem de mata residual. Devido às leis ambientais mais recentes, a mata residual é maior após do $\mathrm{km} 24$ devido à proibição de desmatar mais de $20 \%$ do lote para atividades agropecuárias. Cerca de $20 \%$ dos indivíduos residiam entre o km 14 e 20; $26,5 \%$ entre o km 20-24; 36,1\% entre o 24 e 30, e 13,2\% residiam na Reserva da Linha 14 (da Silva, 2011).

O Ramal do Granada situa-se no maior assentamento agrícola do estado do Acre, o Projeto de Assentamento Dirigido (PAD) Pedro Peixoto, criado pelo Instituto Nacional de Colonização e Reforma Agrária (INCRA) em meados da década de 70, localizado de 30 a $50 \mathrm{Km}$ da área urbana do município de Acrelândia (da Silva, 2011).

Por sua vez, o PAD Pedro Peixoto localiza-se no Estado do Acre, entre os paralelos $9^{\circ} 05^{\prime}$ e $10^{\circ} 30^{\prime}$ e meridianos $66^{\circ} 41^{\prime}$ e $67^{\circ} 40 \mathrm{~W}$. Limitando-se ao norte e nordeste pelo Estado do Amazonas, a leste e sudeste pelo rio Abunã, na fronteira com a Bolívia, e a oeste pela BR-317 (Figura 6) (da Silva-Nunes, 2008).

Figura 6 - Localização do PAD Pedro Peixoto no mapa do Estado do Acre.

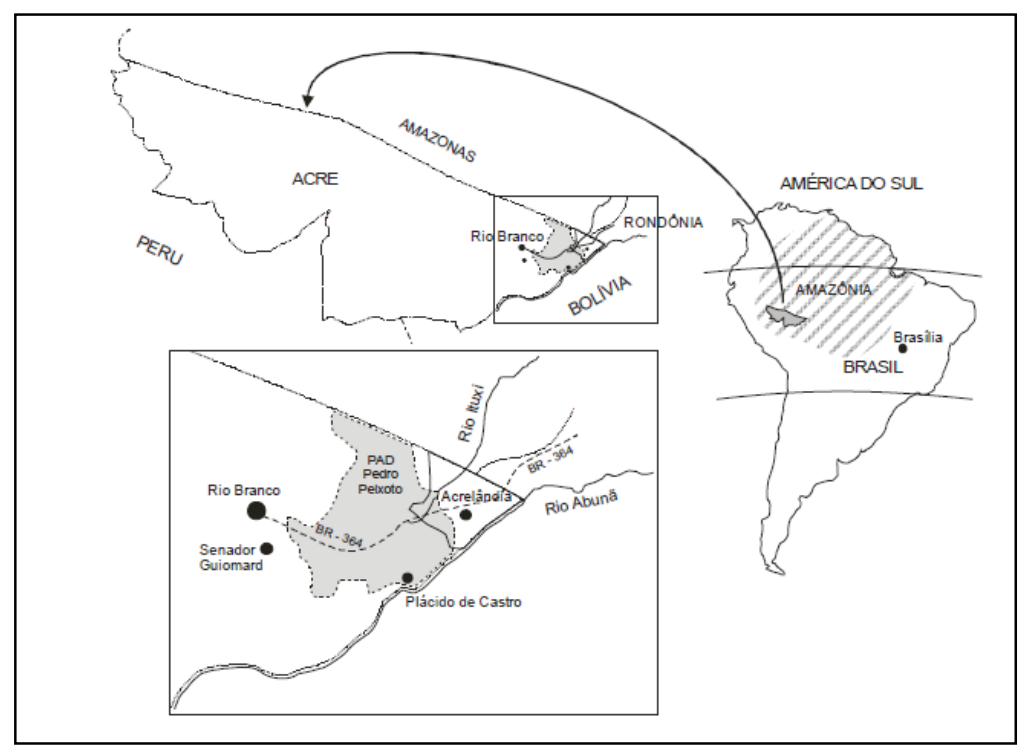

Fonte: da Silva, 2011. 


\subsection{Isolados de Plasmodium falciparum}

Os isolados utilizados neste estudo foram coletados entre 2008 e 2009 em um raio de cerca de $50 \mathrm{~km}$ em torno do Ramal do Granada, em áreas adjacentes pertencentes aos municípios de Plácido de Castro (Acre) e Lábrea (Amazonas). Como controle em alguns experimentos, utilizou-se o clone 3D7, derivado do isolado NF54, obtido em 1979 na Holanda a partir da amostra sanguínea de um paciente que morava próximo do aeroporto de Amsterdã (Walliker et al., 1987).

Os isolados colhidos no campo foram congelados de acordo o método descrito por Ljungström et al. (2004), com a autorização de pacientes residentes na Região Amazônica, diagnosticados entre 2008 e 2009, como mostra a Tabela 2. Os parasitas foram cultivados em nosso laboratório em São Paulo segundo o método descrito por Trager \& Jensen (1976).

Tabela 2 - Origem dos isolados campo de Plasmodium falciparum.

\begin{tabular}{|c|c|c|c|c|c|c|c|}
\hline ISOLADO & KA & 38A & 44A & 94A & FMS & A17 & Pf03 \\
\hline \hline Idade & 3 & 51 & 47 & 33 & 26 & 36 \\
Sexo & masc. & masc. & masc. & fem. & masc. & masc. \\
Data diagnostico & 2008 & $29 / 10 / 2008$ & $31 / 10 / 2008$ & $13 / 08 / 2009$ & $16 / 04 / 2008$ & $31 / 10 / 2008$ \\
Local da Infecção & Remansinho & Remansinho & Remansinho & Remansinho & Acrelândia & Remansinho & Remansinho \\
Estado & Amazonas & Amazonas & Amazonas & Amazonas & Acre & Amazonas \\
Tempo de Amazônia & 3 anos & 31 anos & 38 anos & 23 anos & 26 anos & 12 anos \\
Infecções anteriores & P. vivax/falc. & P. vivax/falc. & P. vivax/falc. & P. vivax/falc. & P.vivax & P. vivax/falc. & P. vivax/falc. \\
\hline
\end{tabular}

\subsection{Cultura de Plasmodium falciparum}

As culturas de $P$. falciparum foram mantidas com meio RPMI-1640 suplementado com 0,5\% Albumax I (Gibco-BRL Life Technologies), seguindo o método descrito por Trager \& Jensen (1976) com algumas modificações. Eritrócitos foram adicionados à cultura obtendo-se um hematócrito de $3 \%$. As garrafas foram mantidas em estufa a $37^{\circ} \mathrm{C}$ com trocas diárias de meio e injeção de uma mistura composta por 5,05\% de $\mathrm{CO}_{2}, 4,93 \%$ 
de $\mathrm{O}_{2}$ e $90,2 \%$ de $\mathrm{N}_{2}$. A parasitemia foi monitorada por microscopia de esfregaços corados pelos componentes do kit Panótico Rápido (Laborclin, São Paulo, SP, Brasil).

Os eritrócitos humanos foram obtidos de doadores do Hospital Sírio Libanês, e posteriormente, de colegas do laboratório, sendo estocados por no máximo por um mês.

\subsection{Congelamento e descongelamento dos isolados de campo}

Os parasitas foram congelados de acordo o método descrito por Ljungström et al. (2004). Eritrócitos com parasitemia acima de 3\%, infectados com parasitas no estágio de anel, foram centrifugados $(227 \times \mathrm{g}$ por 5 minutos à temperatura ambiente [TA]) e o volume do precipitado foi então mensurado, para em seguida ser a ele adicionado 1,666 volumes de glycerolyte estéril, gota a gota, utilizando-se um vortex na posição lenta. Posteriormente, a solução foi transferida a um criotubo deixado por dois dias a $-80{ }^{\circ} \mathrm{C} \mathrm{e}$ depois transferido para o $\mathrm{N}_{2}$ líquido.

Para o descongelamento, depois de retirar a amostra de parasitas do $\mathrm{N}_{2}$ líquido e deixá-la descongelar em gelo, as hemácias infectadas foram transferidas a um tubo de 15 $\mathrm{ml}$ e lentamente adicionado a elas $1 / 5$ do volume do precipitado de cloreto de sódio $12 \%$, sob agitação lenta. Após 1 minuto de incubação a TA, foram adicionados 10 volumes de cloreto de sódio $1,6 \%$, sob constante agitação. Após esta etapa, as hemácias foram centrifugadas a 227 x g por 5 minutos em TA. Na sequência, os parasitas são cultivados sob as condições descritas acima.

\subsection{Teste para Mycoplasma sp}

Para testar a presença de Mycoplasma sp nos cultivos de $P$. falciparum ou de células de mamíferos, $200 \mu \mathrm{l}$ do sobrenadante do cultivo foram centrifugados (10000 x $\mathrm{g}$, por 5 minutos a TA), e o pellet ressuspendido em $50 \mu \mathrm{l}$ de TE e desnaturados por 5 minutos a $95^{\circ} \mathrm{C}$ e então utilizados como template para amplificação do gene $16 \mathrm{~S}$ rRNA de Mycoplasma sp por PCR. Os oligonucleotídeos utilizados serão: MycoA (sense): 5'ggcgaatgggtgagtaaacacg-3' e MycoB (antisense): 5'-cggataacgcttgcgacctat-3'. A reação constitui de $1 \mu$ lde fita molde, 2,0 $\mu$ l de tampão 10x PCR, 2,5 mM de $\mathrm{MgCl}, 0,25 \mathrm{mM}$ de cada dNTP, 0,2 U de Taq DNA polimerase (Amersham Pharmacia Biotech ou Invitrogen 
Corporation, CA, USA), e $5 \mathrm{pmol}$ de cada oligonucleotídeo em volume final de $15 \mu$ l. As condições de amplificação foram: 5 minutos a $94{ }^{\circ} \mathrm{C} ;\left(30\right.$ s a $94{ }^{\circ} \mathrm{C}, 30$ s a $55{ }^{\circ} \mathrm{C}, 30$ s a 72 ${ }^{\circ} \mathrm{C}$ ) repetido em 30 ciclos; e uma polimerização final por 10 minutos a $72{ }^{\circ} \mathrm{C}$ (Rowe et al.,1998).

Os produtos da reação foram analisados em gel de TAE-agarose, de 1,5\% corado com brometo de etídio. No caso de contaminação, seria observado um produto com 400 pb. Uma amostra de DNA genômico (gDNA) de Mycoplasma sp é utilizada como controle positivo da reação.

\subsection{Cultura de células eucarióticas}

Para os ensaios de citoaderência foram utilizadas linhagens de células $\mathrm{CHO}$ (Chinese hamster ovary) transfectadas que expressam seletivamente, em sua superfície, ICAM-1 ou CD36 humano. A linhagem CHO-745 representa a linhagem que teve o gene CSA (chondroitin-4-sulphate) interrompido, servindo de controle nos experimentos. Também foi utilizada a linhagem CHO-K1, que expressa CSA em sua superfície, para a realização de um diagnóstico inicial do fenótipo de aderência dos isolados. Todas as linhagens celulares foram gentilmente doadas pelo Dr. Artur Scherf, do Instituto Pasteur de Paris.

As células foram cultivadas em garrafas de cultivo em meio RMPI-1640 acrescidas de $10 \%(\mathrm{v} / \mathrm{v})$ de soro fetal bovino a $37{ }^{\circ} \mathrm{C}$ em uma atmosfera de $5 \%$ de $\mathrm{CO}_{2}$. As células foram replaqueadas a cada três dias, utilizando-se 0,1\% tripsina-EDTA (Cultilab, Brasil), conforme descrito por Ausubel et al. (1989).

As células HLEC (Human lung endothelial cells) foram cultivadas da mesma forma que as $\mathrm{CHO}$, porém utilizando-se o meio Dulbecco MEM (contendo 0,365 g/L de Lglutamina; 3,15 g/L de D-glicose; 1,2 g/L de $\mathrm{NaHCO}_{3} ; 3,574 \mathrm{~g} / \mathrm{L}$ de HEPES; $\mathrm{pH}$ 7,1 e 310 mOsm), acrescido de $10 \%(\mathrm{v} / \mathrm{v})$ de soro fetal bovino.

As células HLEC utilizadas foram inicialmente doadas ao Dr. Fabio T. M. Costa pelo Dr. Artur Scherf, cujo artigo de 1996 (Muanza et al., 1996) descreve as células como tendo CD36 como molécula preponderantemente expressa. Entretanto, mais recentemente, a equipe do Dr. Fábio T. M. Costa também realizou uma caracterização das mesmas células 
em citômetro de fluxo (FACScanto/Becton \& Dickson) e verificou a grande predominância de ICAM-1 (dados não publicados). Desta forma, consideramos a caracterização mais recente como critério para as nossas análises.

\subsection{Preparação dos parasitas para o ensaio de citoaderência em CHO e HLEC}

Para obter os estágios maduros necessários para a realização do panning, os parasitas foram centrifugados $(227 \times \mathrm{g}$ por 5 minutos à TA). 0 pellet de hemácias foi quantificado e a ele adicionado 2,4 volumes de Voluven 6\% (Fresenius-Kabi, Campinas) e 1,4 volumes do meio incompleto (RPMI-1640). A mistura foi então incubada em posição vertical a $37^{\circ} \mathrm{C}$ por 30 minutos. Os trofozoítos jovens e gametócitos, junto com hemácias não-infectadas, depositam-se no fundo do tubo, enquanto as formas maduras permanecem no sobrenadante. Estas formas foram então transferidas e centrifugadas novamente. Em seguida, os parasitas foram ressuspendidos em meio RPMI-1640 pH 6,8, para os ensaios subsequentes.

\subsection{Ensaio de citoaderência}

\subsubsection{Avaliação da capacidade de citoaderência dos isolados em estudo utilizando CHO}

Para verificar quais isolados expressavam VSAs capazes de aderir a ICAM-1 e CD36, o diagnóstico de adesão, que primeiramente havia sido realizado em frascos de cultura, foi refeito utilizando Lab-Tek microplates e as células $\mathrm{CHO}$ descritas na seção 3.6. Esses ensaios foram realizados no Laboratório de Imunoparasitologia Experimental (LIPEX) situado no Instituto de Biologia da UNICAMP, sob a responsabilidade do professor Dr. Fábio Trindade M. Costa, com especial e imprescindível auxílio da doutoranda Marcele Fontenelle Bastos.

Inicialmente esse mesmo diagnóstico havia sido realizado em nosso laboratório, em garrafas de cultura de $25 \mathrm{~cm}^{2}$ de superfície, onde eram tiradas fotos, contando-se, posteriormente, o número de hemácias aderidas por 100 células CHO. Porém, foi-nos sugerido que utilizássemos as microplacas de 8 poços e portanto esses ensaios foram refeitos. 
Para esses experimentos, os isolados foram cultivados, como descrito anteriormente, as formas maduras foram separadas por floating (seção 3.7), a parasitemia foi verificada, e o hematócrito determinado em câmara de Neubauer. As células $\mathrm{CHO}$ foram colocadas para crescer dois dias antes dos experimentos, utilizando-se meio FCS $10 \%$ e $5 \times 10^{4}$ células por poço. No dia do experimento, as células foram lavadas três vezes com meio RPMI-1640 incompleto ( $\mathrm{pH} 6,8)$, e a seguir, a elas foram incubados $5 \times 10^{4}$ parasitas por poço de Lab-Tek (nos ensaios com células $\mathrm{CHO}$ ), pelo intervalo de uma hora a $37^{\circ} \mathrm{C}$. Após esse período, a microplaca, depois de desmontada, foi lavada para retirar todas as hemácias não aderidas, mergulhando-a 10 vezes em meio RPMI (pH 6,8). Depois de seca, a microplaca foi corada com kit Panótico Rápido para posterior contagem das hemácias parasitadas aderidas em microscópio óptico comum.

\subsubsection{Avaliação da capacidade de citoaderência dos isolados em estudo utilizando HLEC}

Foram realizados dois tipos de experimento utilizando HLEC, ensaios estáticos e em fluxo. Nos ensaios estáticos, os mesmos procedimentos foram realizados (seção 3.8.1), porém além de incubar os incubados $5 \times 10^{4}$ parasitas por poço, também eram adicionados a estes $15 \mu \mathrm{g} / \mathrm{ml}$ de anticorpo em $150 \mu \mathrm{l}$ de meio RPMI (pH 6,8). Estes ensaios foram feitos em triplicatas, ou seja, três poços receberam anticorpo anti-CD36 (FA6-152), outros três anticorpo anti-ICAM-1 (84H10) (ambos do fabricante Santa Cruz) e outros três (grupo controle) não recebeu anticorpo. As contagens foram realizas como descrito anteriormente (seção 3.8.1). Apenas aos últimos isolados a serem analisados, acrescentamos um segundo controle contendo ambos anticorpos.

As análises de citoaderência em fluxo, foram realizadas segundo os métodos empregados por Jurzynski et al. (2007), utilizando-se microplacas Lab-Tek de 1 poço. Aqui, dois tipos de avaliação foram feitos: (1) teste de adesão em fluxo, ou seja, observação da capacidade do parasita aderir às células sob condições de fluxo; (2) teste de desprendimento, ou seja, se os parasitas que aderiram estaticamente seriam capazes de permanecer aderidos às células sob três intensidades de fluxo diferentes.

Para os ensaios de desprendimento, foram incubados $2,5 \times 10^{6} \mathrm{EP}$ em $3 \mathrm{ml}$ de RPMI (pH 6.8), por $1 \mathrm{~h}$ em células HLEC a $37^{\circ} \mathrm{C}$, e em seguidas lavados, mergulhando a Lab-Tek 
desmontada 10 vezes em meio RPMI (pH 6.8). Então, a microplaca foi acoplada ao aparelho de fluxo e foram feitas cerca de 30 fotos (nomeados aqui de "Adesão estática"). Em seguida iniciou-se a passagem de meio RPMI ( $\mathrm{pH}$ 6.8) sob três intensidades de

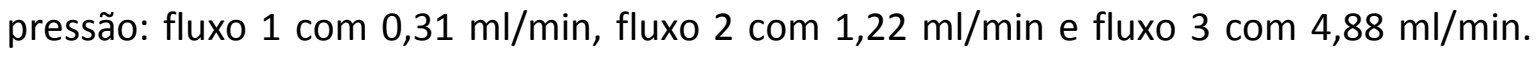
Para cada pressão também foram tiradas fotos, que em seguida foram contadas manualmente usando o programa Image J (http://rsbweb.nih.gov/ij/).

A contagem das fotos não pôde ser automatizada, porque o programa (Image J) não distinguia bem o que eram células, o que eram hemácias e eventuais espaços vazios, uma vez que não podiam ser diferenciadas pela cor. Pesquisando sobre outros programas que automatizavam as contagens, também nos deparamos com a falta de confiabilidade (Ma et al., 2010; Sio et al., 2007).

Para os ensaios de adesão em fluxo, a microplaca coberta por células HLEC foi acoplada ao aparelho de fluxo, onde foram utilizados $3,10 \mathrm{~mL}$ de meio RPMI $(\mathrm{pH} \mathrm{6,8)}$ com hemácias parasitadas a uma pressão de 0,09 Pa (0,31 ml/min). Após 10 minutos de fluxo, a microplaca foi lavada, passando meio RPMI ( $\mathrm{pH}$ 6.8) sob as mesmas condições anteriores para a retirada dos EP que simplesmente pararam com o encerramento do fluxo. Então as fotos foram tiradas.

Para expressar os valores contados nas fotos em gráficos, consideramos como 100\% a média dos EP contados nas fotos antes do fluxo (adesão estática), considerada como o máximo de adesão para ambos experimentos.

\subsubsection{Seleção dos isolados para fenótipos aderentes a CD36 e a ICAM-1 através da técnica de panning}

Os procedimentos de panning feitos com o intuito de se obter isolados aderentes a um dado receptor foram realizados em garrafas de cultura de $25 \mathrm{~cm}^{2}$ de superfície. Células $\mathrm{CHO}$ que expressavam o receptor desejado (CD36 ou ICAM-1) foram replaqueadas dois dias antes do experimento (confluência de 90-100\%), lavadas três vezes com meio RPMI-1640 incompleto (pH 6,8). Posteriormente, as hemácias parasitadas foram acrescentadas às células $\mathrm{CHO}$ e incubadas por $1 \mathrm{~h}$ a $37^{\circ} \mathrm{C}$, com agitação leve intermitente a cada 15 minutos. Em seguida, as hemácias não aderidas foram aspiradas e as células, lavadas três vezes com meio RPMI-1640 incompleto ( $\mathrm{pH} \mathrm{6,8).} \mathrm{As} \mathrm{hemácias} \mathrm{aderidas} \mathrm{foram}$ 
removidas das células com meio RPMI-1640 completo alcalino $(\mathrm{pH} 7,2)$ e colocadas em cultivo, como já descrito. Esses procedimentos foram repetidos cinco vezes para cada receptor (CD36 e ICAM-1), para quase todos os isolados. A fim de evitar a contaminação do cultivo com células $\mathrm{CHO}$, este foi transferido um dia após o panning para uma nova garrafa (Pouvelle et al., 2000).

As avaliações do perfil de citoaderência estáticos pós-panning, foram realizados em Lab-Tek microplates de oito poços, como descrito na seção 3.8.1.

\subsection{Imunofluorescência das células CHO}

Os ensaios de imunofluorescência foram realizados para averiguar se as células CHO estavam expressando os receptores CD36 ou ICAM-1 em suas superfícies utilizando, como sugerido pela banca de qualificação.

Foram utilizados como anticorpos primários: anticorpo ICAM-1 (84H10), e anticorpo CD36 (FA6-152) do fabricante Santa Cruz; e como anticorpo secundário, o antiIgG mouse marcado com AlexaFluor 594 (vermelho). E para a marcação das células, utilizou-se DAPI (azul), presente no composto Vectashield.

As células foram colocadas para crescer em microplacas de 16 poços dois dias antes do experimento. Este consistiu em uma etapa inicial de fixação com paraformaldeído (PFA) 1,6\% por 15 minutos a TA, seguido de uma lavagem com PBS [1x] por 10 minutos. Em seguida foi feito o bloqueio com FCS 1\% + BSA 1\% em solução PBS [1x] por 30 minutos. Após a lavagem das células, elas foram incubadas por 30 minutos com o anticorpo primário (1:200), seguido de novas lavagens. O anticorpo secundário (1:300) foi então utilizado em uma incubação de 30 minutos e após lavar as células, a LabTek foi desmontada, e depois de seca, adicionou-se Vectashield a ela, cobrindo com lamínula e incubando durante a noite a $4{ }^{\circ} \mathrm{C}$, no escuro.

A aquisição das imagens foi feita dia seguinte em microscopia de fluorescência, através do programa Axio Vision (http://microscopy.zeiss.com/ microscopy/en_de/products/microscope-software/axiovision-for-biology.html). 


\subsection{Western blot das células $\mathrm{CHO}$}

As células foram coletas da cultura com a utilização de cell-scraper. Após obter um pellet de células, estas foram ressuspendidas em $50 \mu \mathrm{l}$ de solução contendo inibidor de protease $[1 \mathrm{x}]$.

As células foram lisadas em solução hipotônica por 10 minutos de centrifugação a $14000 \times$ g. O sobrenadante foi descartado e ao pellet, adicionado tampão de corrida SDS (Sodium Dodecyl Sulfate). A eletroforese foi realizada a $100 \mathrm{~V}$ e $400 \mathrm{~mA}$.

Para a transferência, utilizou-se tampão contendo $20 \%$ de metanol, para a ativação da membrana de nitrocelulose (Hybond-C, Amersham-Pharmacia, NJ, EUA), sob uma corrente elétrica de $90 \mathrm{~V}$ a $400 \mathrm{~mA}$ por uma hora. Em seguida, a membrana foi incubada com solução de bloqueio (PBS-Tween 0,05\% e leite 2\%) por 10 minutos em leve agitação. Após lavagens, a membrana permaneceu overnight, a $4{ }^{\circ} \mathrm{C}$, com o anticorpo primário (anti-CD36/ICAM-1) na diluição 1:2000 em PBS-Tween 0,05\% e leite 1\%.

As membranas foram, então, lavadas em PBS-Tween 0,05\%, reveladas por quimioluminescência (kit SuperSignal, Pierce) e logo em seguida, foram expostas ao filme Hyperfilm, seguindo as instruções do fabricante.

\subsection{Citometria das células $\mathrm{CHO}$}

As células foram coletas da cultura com a utilização de cell-scraper. Após obter um pellet de células, estas foram bloqueadas em BSA [1x] por 30 minutos, lavadas três vezes em PBS [1x] e incubadas por uma hora, em gelo, com anticorpo anti-CD36/ICAM-1 ou soro controle não relacionado, todos em diluição 1:200.

Após três lavagens, as células foram incubadas com anti-mouse Alexa 594 (1:500), por uma hora em gelo, seguido de três lavagens. As células foram ressuspendidas em $\mathbf{4 0 0}$ $\mu$ l e os 19000 eventos foram captados e analisados no programa Guava EasySoft. 


\subsection{Citometria de fluxo para avaliar reconhecimento por anticorpos}

Os ensaios de citometria de fluxo foram realizados em microplacas de 96 poços (Corning Costar, EUA). Um dia antes do experimento as placas foram bloqueadas com 100 $\mu \mathrm{l}$ de solução R-FCS (RPMI+FCS $2 \%, \mathrm{pH} 7,2$ ) a $4{ }^{\circ} \mathrm{C}$.

Foram utilizados trofozoítos maduros $\left(5 \times 10^{6}\right.$ parasitas) derivados de culturas sincronizadas de cada isolado de $P$. falciparum a uma parasitemia de $2 \%$. Após os parasitas passarem por uma etapa de 30 minutos de bloqueio em solução R-FCS, os mesmos foram incubados por 20 minutos com brometo de etídio (100 $\mu \mathrm{g} / \mathrm{ml}$ em PBS) para marcação dos eritrócitos parasitados (EP).

Após duas lavagens em solução P-FCS (PBS + FCS 1\%), o pellet foi ressuspendido em P-FCS, distribuído na placa e incubado, em triplicatas, com soro de pacientes (procedência de acordo com a seção 3.1), pool de soros negativos (de 12 pessoas não expostas) e com controle positivo, todos diluídos a 1:10. Como controle positivo, utilizamos um pool de imunoglobulinas provenientes de africanos adultos clinicamente imunes e continuamente expostos à malária de uma região holoendêmica (BouharounTayoun et al., 1990; Gysin et al., 1996). Este pool se mostrou eficaz após transferência passiva a pessoas não imunes (Bouharoun-Tayoun et al., 1990) e a macacos-de-cheiro (Gysin et al., 1996). Uma alíquota liofilizada desse pool foi gentilmente cedida pelo Professor L. Pereira da Silva (à época no Instituto Pasteur, Paris, França) em 1992, e diluído em PBS para a concentração final de $2,5 \mathrm{~g} / 100 \mathrm{ml}$.

Após 30 minutos de incubação dos EP com os soros, foram realizadas duas lavagens em P-FCS, seguido de uma incubação com $25 \mu \mathrm{l}$ de anticorpo anti-IgG humano conjugado com AlexaFluor 488 (diluído a 1:600 em PBS) por outros 30 minutos.

Após duas lavagens em solução P-FCS e uma em PBS [1x], as hemácias foram ressuspendidas em PBS [1x], de modo que a concentração de células estivesse próxima de 500 células/ $\mu$ l, para a leitura em citômetro de fluxo Guava easyCyte HT (Millipore).

Antes de iniciar a aquisição das amostras, era realizada uma compensação, excluindo-se o sinal do brometo de etídio do canal verde e o sinal do anti-IgG conjugado com AlexaFluor 488 do canal vermelho, através da passagem de amostras marcadas com cada um dos fluorocromos individualmente. Para cada uma das reações foram analisados 
15.000 eventos. Os dados foram captados e analisados no programa Guava ExpressPro 8.1.

Para definir a média geométrica da intensidade de fluorescência (MIF) de cada soro, os quadrantes foram posicionados para medir a MIF dos EP marcados com brometo de etídio. Desta forma, a reatividade contra a superfície dos EP foi expressa como a diferença entre a MIF dos EP e a MIF dos eritrócitos não infectados (Chan et al., 2012; Elliott et al., 2007; Feng et al., 2009; Mayor et al., 2012). As respostas IgG anti-VSA foram consideradas positivas quando o valor da MIF de cada trio soro/isolado era superior à média dos 12 controles negativos acrescida de três desvios padrão (Chan et al., 2012).

A intensidade de reconhecimento de cada isolado fenótipo pelos soros testados foi expressa tomando-se como $100 \%$ os valores de MIF detectados para o controle positivo (pool africano). Deste modo, uma intensidade de reconhecimento de $42 \%$, por exemplo, significa que aquela amostra teve um valor médio de MIF correspondente a $42 \%$ do valor obtido, com o mesmo isolado, com o pool de soros controles positivos.

\subsection{Ensaio de bloqueio de adesão em células $\mathrm{CHO}$}

Dois dias antes de cada ensaio, $5 \times 10^{4}$ células/poço de CHO-ICAM1 ou CHO-CD36 em meio FCS $10 \%$ foram cultivadas em lâminas Lab-Tek (BD e Nunc) de 8 poços para atingirem confluência. No dia do experimento, as células foram lavadas três vezes com meio RPMI $(\mathrm{pH} 6,8)$ e a elas, foram adicionados $5 \times 10^{4}$ trofozoítos maduros de $P$. falciparum e soros (selecionados conforme os resultados da citometria) com diluições conforme as Tabelas 3-6. Após 1 h de incubação a $37{ }^{\circ} \mathrm{C}$, a microplaca foi desmontada e lavada para retirar todas as hemácias não aderidas, mergulhando-a 10 vezes em meio RPMI (pH 6,8). Depois de seca, a lâmina resultante foi corada com kit Panótico Rápido para posterior contagem das hemácias parasitadas aderidas em microscópio óptico comum.

Para esse experimento, foram selecionados soros com maiores índices de reatividade contra um isoladofenótipo, de modo que, para o fenótipo adesivo a CD36, enquanto o soro 426 reconhece bem a superfície da hemácia infectada do isolado $38 \mathrm{~A}^{\mathrm{CD} 36}$, esse mesmo soro não reconhece bem VSAs do isolado FMS também selecionado para CD36 (Figura 7-A). Em contrapartida, o reconhecimento do soro 517 apresentou 
característica oposta, reconhecendo bem o isolado $\mathrm{FMS}^{\mathrm{CD} 36}$ e pouco o $38 \mathrm{~A}^{\mathrm{CD} 36}$. O tipo de seleção foi feito para os dois isolados mais adesivos a ICAM-1 (Figura 7-B).

Alguns dos soros, considerados "melhores respondedores" a um determinado isoladofenótipo, não puderam ser selecionados devido à escassez de material para todos os ensaios. Lembramos aqui que os valores da Figura 7 foram originados tomando-se o controle positivo (pool africano) como $100 \%$ de reconhecimento.

Figura 7 - Porcentagem de reconhecimento dos soros aos isolados de campo por citometria de fluxo
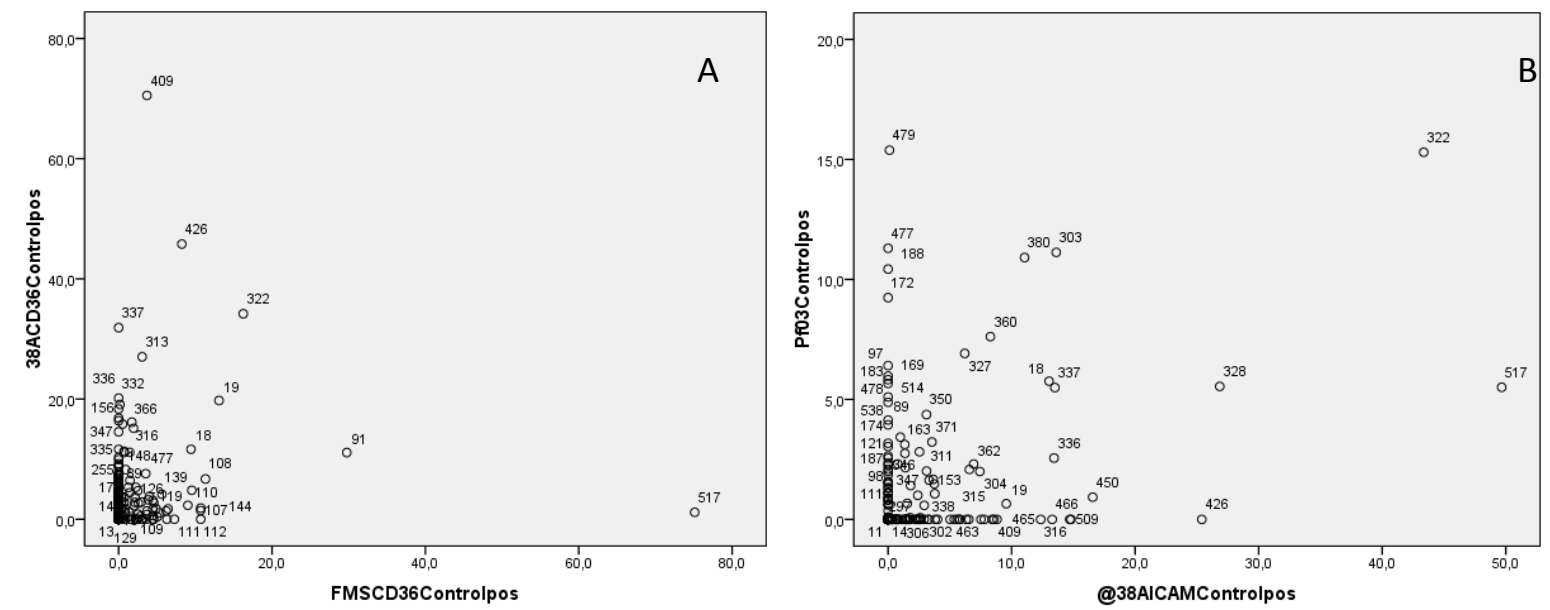

O eixo das abcissas, em A, apresenta em seu extremo os soros que melhor reconheceram a superficie da hemácia infectada por $\mathrm{FMS}^{\mathrm{CD} 36}$, enquanto no eixo das ordenadas, apresenta aqueles soros que melhor reconheceram a superficie da hemácia infectada por isolado $38 \mathrm{~A}^{\mathrm{CD} 36}$. Em $\mathrm{B}$, temos o reconhecimento de $38 A^{\text {ICAM1 }}$ no eixo das abcissas e PfO3 no eixo odenadas. 
Tabela 3 - Reprodução da montagem da microplaca Lab-Tek para o isolado 38A ${ }^{\mathrm{CD} 36}$.

\begin{tabular}{|c|c|c|c|c|}
\hline $5 \times 10^{4} \mathrm{CHO}-\mathrm{CD} 36$ & $5 \times 10^{4} \mathrm{CHO}-\mathrm{CD} 36$ & $5 \times 10^{4} \mathrm{CHO}-\mathrm{CD} 36$ & $5 \times 10^{4} \mathrm{CHO}-\mathrm{CD} 36$ & Efeito dos soros \\
\hline $5 \times 10^{4}$ isolado $38 A^{\mathrm{CD} 36}$ & $5 \times 10^{4}$ isolado $38 A^{\operatorname{CD} 36}$ & $5 \times 10^{4}$ isolado $38 A^{\text {CD36 }}$ & $5 \times 10^{4}$ isolado $38 A^{\mathrm{CD} 36}$ & 426 e $517 \mathrm{na}$ \\
\hline Soro 426 (1:100) & Soro 426 (1:25) & Soro 426 (1:10) & Controle Sem Soro & Adesão de \\
\hline $5 \times 10^{4} \mathrm{CHO}-\mathrm{CD} 36$ & $5 \times 10^{4} \mathrm{CHO}-\mathrm{CD} 36$ & $5 \times 10^{4} \mathrm{CHO}-\mathrm{CD} 36$ & $5 \times 10^{4} \mathrm{CHO}-\mathrm{CD} 36$ & em CHO-CD36 \\
\hline $5 \times 10^{4}$ isolado $38 A^{\text {CD36 }}$ & $5 \times 10^{4}$ isolado $38 A^{\text {CD36 }}$ & $5 \times 10^{4}$ isolado $38 A^{\text {CD36 }}$ & $5 \times 10^{4}$ isolado $38 A^{\mathrm{CD} 36}$ & \\
\hline Soro 517 (1:100) & Soro $517 \quad(1: 25)$ & Soro 426 (1:10) & Anticorpo anti-CD36 1:25 & \\
\hline
\end{tabular}

Tabela 4 - Reprodução da montagem da microplaca Lab-Tek para o isolado FMS ${ }^{\mathrm{CD} 36}$.

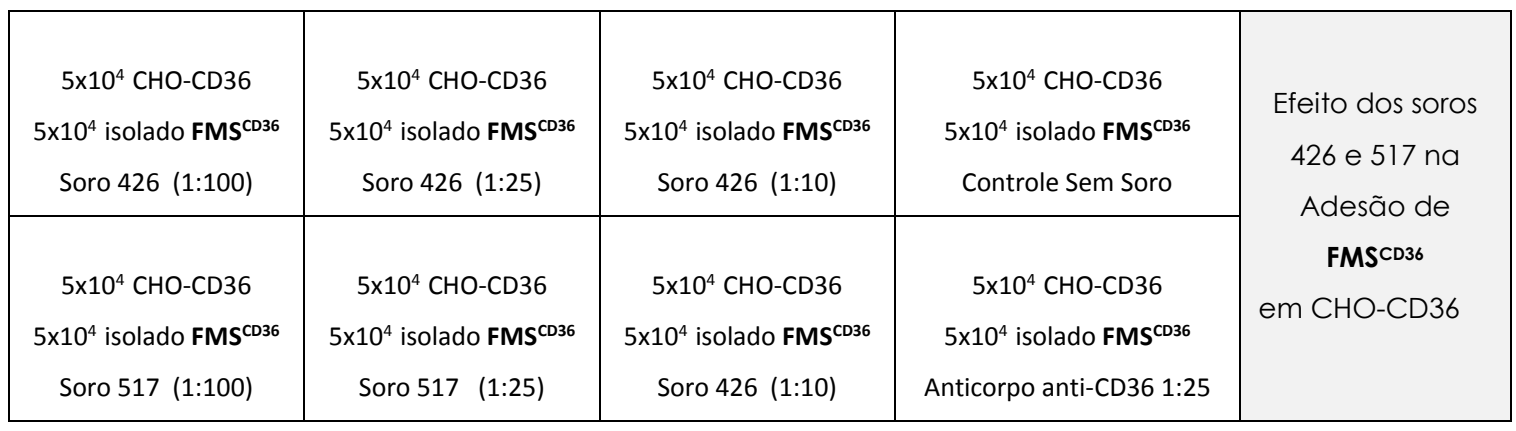

Tabela 5 - Reprodução da montagem da microplaca Lab-Tek para o isolado 38A ICAM1.

\begin{tabular}{|c|c|c|c|c|}
\hline $\begin{array}{c}5 \times 10^{4} \text { CHO-ICAM1 } \\
5 \times 10^{4} \text { isolado } 38 A^{\text {ICAM }} \\
\text { Soro } 426(1: 100)\end{array}$ & $\begin{array}{c}5 \times 10^{4} \text { CHO-ICAM1 } \\
5 \times 10^{4} \text { isolado } 38 A^{\text {ICAM }} \\
\text { Soro } 426(1: 25)\end{array}$ & $\begin{array}{c}5 \times 10^{4} \text { CHO-ICAM1 } \\
5 \times 10^{4} \text { isolado } 38 A^{\text {ICAM }} \\
\text { Soro } 426(1: 10)\end{array}$ & $\begin{array}{c}5 \times 10^{4} \text { CHO-ICAM1 } \\
5 \times 10^{4} \text { isolado 38A } \\
\text { Controle Sem Soro }\end{array}$ & $\begin{array}{c}\text { Efeito dos soros } \\
426 \text { e } 477 \text { na } \\
\text { Adesão de }\end{array}$ \\
\hline $\begin{array}{c}5 \times 10^{4} \text { CHO-ICAM } 1 \\
5 \times 10^{4} \text { isolado } 38 A^{\text {ICAM }}\end{array}$ & $\begin{array}{c}5 \times 10^{4} \text { CHO-ICAM1 } \\
5 \times 10^{4} \text { isolado } 38 A^{\text {ICAM }}\end{array}$ & $\begin{array}{c}5 \times 10^{4} \text { CHO-ICAM1 } \\
5 \times 10^{4} \text { isolado } 38 A^{\text {ICAM }}\end{array}$ & $\begin{array}{c}5 \times 10^{4} \text { CHO-ICAM1 } \\
5 \times 10^{4} \text { isolado } 38 A^{\text {ICAM }}\end{array}$ & $\begin{array}{c}\text { 38A'ICAM 5x } \\
\text { em }\end{array}$ \\
\hline Soro 477 (1:100) & Soro 477 (1:25) & Soro 477 (1:10) & Anticorpo anti-CD36 1:25 & CHO-ICAMI \\
\hline
\end{tabular}


Tabela 6 - Reprodução da montagem da microplaca Lab-Tek para o isolado Pf03.

\begin{tabular}{|c|c|c|c|c|}
\hline $5 \times 10^{4}$ CHO-ICAM 1 & $5 \times 10^{4}$ CHO-ICAM 1 & $5 \times 10^{4}$ CHO-ICAM1 & $5 \times 10^{4}$ CHO-ICAM1 & \multirow{6}{*}{$\begin{array}{c}\text { Efeito dos soros } \\
426 \text { e } 477 \text { na } \\
\text { Adesão de Pf03 } \\
\text { em } \\
\text { CHO-ICAMl }\end{array}$} \\
\hline $5 \times 10^{4}$ isolado Pf03 & $5 \times 10^{4}$ isolado $\mathrm{Pf03}$ & $5 \times 10^{4}$ isolado Pf03 & $5 \times 10^{4}$ isolado $\mathrm{Pf03}$ & \\
\hline Soro 426 (1:100) & Soro $426(1: 25)$ & Soro 426 (1:10) & Controle Sem Soro & \\
\hline $5 \times 10^{4}$ CHO-ICAM1 & $5 \times 10^{4}$ CHO-ICAM 1 & $5 \times 10^{4}$ CHO-ICAM 1 & $5 \times 10^{4}$ CHO-ICAM1 & \\
\hline $5 \times 10^{4}$ isolado $\mathrm{PfO3}$ & $5 \times 10^{4}$ isolado $\mathrm{Pf03}$ & $5 \times 10^{4}$ isolado Pf03 & $5 \times 10^{4}$ isolado $\mathrm{Pf03}$ & \\
\hline Soro 477 (1:100) & Soro 477 (1:25) & Soro 477 (1:10) & Anticorpo anti-CD36 1:25 & \\
\hline
\end{tabular}

Os ensaios foram conduzidos em duplicatas (duas microplacas para cada isolado) em volumes de $100 \mu \mathrm{l}$. A citoaderência foi avaliada pela contagem de hemácias infectadas aderentes, e os resultados foram expressos em porcentagem de bloqueio, tomando-se como $100 \%$ o controle de isolados incubados sem a presença de soro.

\subsection{Ensaio de bloqueio de adesão em CD36 e ICAM-1 recombinantes}

Inicialmente tentamos realizar esses experimentos em microplacas Lab-Teks de permanox (oito poços), mas devido a quase dois meses de insucesso, com diversas tentativas de concentrações e tampões diferentes, optamos por realizar os ensaios em placas de 96 poços (High binding, Corning, Costar, EUA).

A adesão da proteína recombinante à placa foi realizada a $4{ }^{\circ} \mathrm{C}$ por $15 \mathrm{~h}$, um dia antes do experimento, utilizando-se $50 \mu \mathrm{l} /$ poço da proteína diluída a $5 \mathrm{ug} / \mathrm{ml}$ em tampão carbonato/bicarbonato $(50 \mathrm{mM}, \mathrm{pH} 9,8)$.

As formas maduras dos parasitas foram concentradas como descrito na seção 3.7, e utilizados $5 \times 10^{5} \mathrm{EP} /$ poço.

Primeiramente a placa foi bloqueada por 1 hora a $37^{\circ} \mathrm{C}$ com $100 \mu$ de solução PBS $[1 \mathrm{x}]+$ BSA 1\%, seguida de uma lavagem com PBS [1x]. Enquanto isso, os parasitas foram marcados com brometo de etídio $(10 \mu \mathrm{g} / \mathrm{ml})$ por 20 minutos, e após três lavagens com PBS [1x], os parasitas foram eluídos em RPMI. Para cada poço, foram utilizados $50 \mu \mathrm{l}$ dessa solução de EP, onde também foram adicionados os mesmos soros descritos na seção 3.10, sob as mesmas diluições. 
Após 1 hora de incubação a $37{ }^{\circ} \mathrm{C}$, foram realizadas cerca de três ou quatro cuidadosas lavagens com o tampão PBS [1x]. A placa foi então, tripsinizada com uma solução 1:10 (v/v) de tripsina (Solução tripsina/EDTA $250 \mathrm{mg} \%$ - 2,5 g/L de tripsina com atividade 1:250 - do fabricante Vitrocell) em RPMI. Transcorridos 30 minutos, adicionou-se $150 \mu$ l de RPMI + SFB 10\% e o número de EP que estavam aderidas foram contadas através do citômetro de fluxo Guava easyCyte HT (Millipore), após o ajuste no canal do brometo, onde delimitamos a positividade das hemácias infectadas

Uma vez que as soluções dos poços eram homogeneizadas, utilizamos como critério o número de EP encontrados em $124 \mu$ l (3 minutos e 30 segundos, tempo máximo de aquisição), pois estabelecer um número de eventos poderia gerar um viés nos resultados.

Como controle do experimento, incubamos três poços (contendo a proteína) com anticorpo específico (anti-CD36) em três concentrações diferentes (1:10, 1:100 e 1:1000), de modo que ao observarmos uma adesão de parasitas numa ordem crescente para essas diluições, poderíamos julgar nossos resultados confiáveis. Utilizamos também como controle, poços sem a proteína (apenas incubado com BSA 1\%), de forma que as lavagens eram consideradas suficientes quando observávamos nenhuma ou poucas hemácias ao microscópio invertido.

Para a análise dos resultados, consideramos como $100 \%$ de adesão ou $0 \%$ de bloqueio a réplica incubada com um pool de soros negativos na concentração 1:10, que na grande maioria das vezes foi muito próxima da réplica sem adição de soro.

\subsection{ELISA para detecção de ICAM-1 recombinante}

Após várias tentativas infrutíferas de adesão dos nossos parasitas ao receptor recombinante ICAM-1, realizamos um imunoensaio enzimático (ELISA) para comprovar que o receptor estava mesmo aderido à placa, e diferente do que observamos com CD36, os isolados utilizados não foram capazes de aderir ao receptor isoladamente.

As proteínas foram testadas em duas concentrações (10 e $20 \mu \mathrm{g} / \mathrm{ml}$ de ICAM-1) e em dois tampões: em tampão carbonato-bicarbonato (Sigma, EUA) e em PBS [1x]. Como controle, também utilizamos dois poços somente com solução BSA $1 \%$. Desta forma, a 
sensibilização foi feita em uma microplacas de 96 poços (High binding, Corning, Costar, EUA) incubando-se a proteína recombinante e o BSA $1 \%$ por $15 \mathrm{~h}$ a $4{ }^{\circ} \mathrm{C}$.

O excesso da solução contendo os antígenos foi retirado por inversão, sendo as microplaca lavada por três vezes com uma solução contendo PBS-Tween 20 (SigmaAldrich) a 0,05\% (PBS-T). A cada poço da placa foram adicionados $200 \mu$ da solução de bloqueio constituída por PBS-T e 5\% de leite em pó desnatado. Após 2 h de bloqueio a 37 ${ }^{\circ} \mathrm{C}$, a microplaca foi lavada cinco vezes com PBS-T.

Em seguida, foram adicionados $50 \mu \mathrm{l}$ do anticorpo anti-ICAM-1, diluído a 1:1000 em tampão PBS-T contendo $4 \%$ de leite em pó desnatado. Após um período de incubação a $37^{\circ} \mathrm{C}$ por $1 \mathrm{~h}$, a microplaca foi lavada dez vezes com a solução de PBS-T.

Após o processo de lavagem, a microplaca foi novamente incubada a $37^{\circ} \mathrm{C}$ por $1 \mathrm{~h}$, com $50 \mu \mathrm{l} /$ poço do conjugado anti-lgG humana ligada à peroxidase, em uma diluição de 1:1000 com PBS-T contendo 4\% de leite em pó desnatado.

Após dez lavagens, a microplaca foi revelada, acrescentando-se $50 \mu \mathrm{l} /$ poço de uma solução contendo TMB (Tetrametilbenzidina - BD Pharmingen). A reação foi interrompida após 10 minutos pela adição de $25 \mu$ de uma solução de ácido cloridríco $2 \mathrm{~N}$.

A leitura foi realizada medindo-se a absorbância da microplaca com filtro de $450 \mathrm{~nm}$ em um leitor automático de ELISA (Epoch, Biotec).

\subsection{Extração de DNA para análise de microssatélites e detecção dos genes pfhrp2 e pfhrp3 e kahrp}

A extração de DNA das amostras foi realizado através do QIAamp Blood mini kit (Qiagen), de acordo com as normas do fabricante. Exceto para amostra KA, o método utilizado foi o de fenol-clorofórmio, por se tratar de uma amostra congelada e, portanto conter glicerol, o que impossibilita o uso das colunas do kit.

Para a extração com fenol, a amostra foi lavada uma vez com PBS [1x], e uma alíquota de $200 \mu \mathrm{l}$ das hemácias infectadas foi lisada com saponina 0,1\% em PBS [1x]. Após 10 minutos de incubação

à TA, os parasitas foram centrifugados por 5 minutos a 2500 x g à TA, e o precipitado foi ressuspendido em $600 \mu \mathrm{l}$ de TE e $200 \mu \mathrm{l}$ de tampão de lise [4x] contendo 0,1 mg/ml de 
proteinase $\mathrm{K}$ de concentração final. A amostra foi incubada a $37{ }^{\circ} \mathrm{C}$ por $3 \mathrm{~h}$ ou durante a noite. Em seguida, foram adicionados $800 \mu \mathrm{l}$ de fenol equilibrado em TE, mantendo-se o tubo em agitação branda por 10 minutos a TA, seguido de uma centrifugação a 5000 x g por 8 minutos a TA. A fase aquosa foi transferida para um novo tubo e a este adicionados $800 \mu \mathrm{l}$ de clorofórmio. A fase aquosa foi ressuspendida, após nova agitação e centrifugação, e tratada com RNAse A por 30 minutos a TA. Após repetir a purificação com fenol/clorofórmio, a fase aquosa foi transferida a um novo tubo, adicionando-se $1 / 10$ do volume de acetato de sódio $3 \mathrm{M} \mathrm{pH} \mathrm{5,2} \mathrm{e} \mathrm{2,5} \mathrm{volumes} \mathrm{de} \mathrm{etanol} \mathrm{100 \% .} \mathrm{O} \mathrm{DNA} \mathrm{foi}$ precipitado a $4{ }^{\circ} \mathrm{C}$ por $2 \mathrm{~h}$ ou durante a noite, e então, centrifugado a $5000 \times \mathrm{g}$ por 30 minutos a $4{ }^{\circ} \mathrm{C}$. O precipitado foi lavado com $500 \mu \mathrm{l}$ de etanol $70 \%$ e centrifugado a $5000 \mathrm{x}$ g por 5 minutos a TA. Para finalizar, o precipitado foi seco e ressuspendido em $50 \mu \mathrm{l}$ de TE.

\subsection{Tipagem molecular de $P$. falciparum}

\subsubsection{Análise de Microssatélites}

A tipagem das amostras de $P$. falciparum foi realizada com a utilização de 10 marcadores de DNA microssatélite descritos por Anderson et al. (1999) (Tabela 7), em que 6-FAM, NED, VIC são os três marcadores fluorescentes, incorporados ao oligonucleotídeo anterior (F), utilizados para visualizar os fragmentos amplificados no sequenciador de DNA. Cada um dos marcadores foram amplificados individualmente usando Taq DNA polimerase e os fragmentos, analisados através de um sequenciador automático de DNA ABI310 (Applied Biosystems), instalado no Departamento de Parasitologia do Instituto de Ciências Biomédicas de São Paulo. 
Tabela 7 - Oligonucleotídeos utilizados para a amplificação dos 10 marcadores microssatélites de DNA (MSAT) em amostras de $P$. falciparum.

\begin{tabular}{|c|c|c|c|}
\hline MSAT & $\begin{array}{l}\text { Cromossomo de } P . \\
\text { falciparum }\end{array}$ & No. GenBank & Oligonucleotídeos \\
\hline TA1-3 & 6 & AF010507 & $\begin{array}{l}\text { F: 6-FAMCTACATGCCTAATGAGCA } \\
\text { R: TTTTATCTTCATCCCCAC }\end{array}$ \\
\hline Poly $\alpha$ & 4 & L18785 & $\begin{array}{l}\text { F: VICAAAATATAGACGAACAGA } \\
\text { R: ATCAGATAATTGTTGGTA }\end{array}$ \\
\hline TAA60 & 13 & AF010556 & $\begin{array}{l}\text { F: VICCTCAAAGAAAAATAATTCA } \\
\text { R: AAAAAGGAGGATAAATACAT }\end{array}$ \\
\hline ARA2 & 11 & $\mathrm{X} 17484$ & $\begin{array}{l}\text { F: NEDGTACATATGAATCACCAA } \\
\text { R: GCTTTGAGTATTATTAATA }\end{array}$ \\
\hline PFPK2 & 12 & X63648 & $\begin{array}{l}\text { F: NEDCTTTCATCGATACTACGA } \\
\text { R: CCTCAGACTGAAATGCAT }\end{array}$ \\
\hline TAA87 & 6 & AF010571 & $\begin{array}{l}\text { F: VICTGGGTTTAAAATGAGGTACA } \\
\text { R: ACATGTTCATATTACTCAC }\end{array}$ \\
\hline TAA109 & 6 & AF010508 & $\begin{array}{l}\text { F: 6-FAMTAGGGAACATCATAGGAT } \\
\text { R: CCTATACCAAACATGCTAAA }\end{array}$ \\
\hline TAA81 & 5 & AF010510 & $\begin{array}{l}\mathrm{F}: \underline{6 F A M G A A G A A A T A A G G G A A G G T} \\
\mathrm{R}: \text { TTTCACACAACACAGGATT }\end{array}$ \\
\hline TAA42 & 5 & AF010543 & $\begin{array}{l}\text { F: VICACAAAAGGGTGGTGATTCT } \\
\text { R: GTATTATTACTACTACTAAAG }\end{array}$ \\
\hline 2490 & 10 & T02490 & $\begin{array}{l}\text { F: 6-FAMTTCTAAATAGATCCAAAG } \\
\text { R: ATGATGTGCAGATGACGA }\end{array}$ \\
\hline
\end{tabular}

Fonte: Orjuela-Sanchez, 2013.

A reação de amplificação constituiu-se de $3 \mu \mathrm{l}$ de gDNA (extraídos conforme a seção 3.7), 1,5 $\mu$ lde tampão $10 x-\mathrm{NH}_{4}$ PCR, $2,5 \mathrm{mM}$ de $\mathrm{MgCl}_{2}$, 2,5 mM de cada dNTP, 1,25 $\mathrm{U}$ de Taq DNA polimerase (Amersham Pharmacia Biotech ou Invitrogen Corporation, CA, USA), e $2 \mu \mathrm{M}$ de cada oligonucleotídeo em volume final de $15 \mu \mathrm{l}$. As condições de amplificação foram: 2 minutos a $94{ }^{\circ} \mathrm{C}$; $\left(30\right.$ s a $94{ }^{\circ} \mathrm{C}, 30$ s a $42{ }^{\circ} \mathrm{C}, 30$ s a $40{ }^{\circ} \mathrm{C}$ e 40 s a 65 $\left.{ }^{\circ} \mathrm{C}\right)$ repetido em 40 ciclos; e uma polimerização final por 15 minutos a $65^{\circ} \mathrm{C}$.

Foram analisados os isolados antes do panning (A17, 94A, 44A, 38A, Pf03, FMS e KA), pós-panning para CD36 (todos, exceto A17) e para ICAM-1 (todos, exceto A17) para cada um dos 10 marcadores.

Após a reação de amplificação dos marcadores, cada produto de PCR foi diluído 10 ou 11 vezes em água ultrapura. A partir desta diluição, 0,5 ou $1 \mu$ l de cada marcador foi misturado em aproximadamente $14 \mu \mathrm{l}$ de formamida Hi-Di (Applied Biosystems), tendo como marcador de peso molecular 0,3 $\mu$ l de Gene-Scan ROX 500 (Applied Biosystems) por reação. 
Para a análise do tamanho dos fragmentos através do sequenciador, os microssatélites foram agrupados em conjuntos de 2 a 3 marcadores por tubo de corrida segundo sua fluorescência e seu tamanho aproximado (Tabela 8).

Tabela 8 - Descrição dos oligonucleotídeos.

\begin{tabular}{|l|c|c|c|c|c|c|c|c|c|c|}
\hline LOCUS & TA1 & Poly- $\alpha$ & TAA60 & ARA2 & PFPK2 & TAA87 & TAA109 & TAA81 & TAA42 & 2490 \\
\hline NOME MSTA & PF1 & PF2 & PF3 & PF4 & PF6 & PF7 & PF8 & PF9 & PF10 & PF11 \\
\hline DYE & FAM & VIC & VIC & NED & NED & VIC & FAM & FAM & VIC & FAM \\
\hline COR & azul & verde & verde & amarelo & amarelo & verde & azul & azul & verde & Azul \\
\hline GEL - tam. aprox & 206 & 205 & 202 & 172 & 244 & 166 & 262 & 178 & 243 & 141 \\
\hline
\end{tabular}

Fonte: Orjuela-Sanchez, 2013.

\subsubsection{Análise dos dados de microssatélites de DNA}

O programa Genescan (Applied Biosystem) foi utilizado para medir o tamanho dos fragmentos amplificados e a altura dos picos (que corresponde aproximadamente à abundância relativa de parasitas com cada alelo na amostra), um parâmetro fundamental para a análise de infecções geneticamente mistas (Anderson et al., 1999). Para cada isolado foi atribuído um ou mais haplótipos correspondentes aos alelos encontrados em cada marcador, caso o pico obtido no segundo alelo tenha altura, medida com o programa Genescan, correspondente a pelo menos um terço da altura do pico majoritário (Anderson et al., 2000).

\subsection{Deteç̧ão dos genes pfhrp2 e pfhrp3}

A detecção dos genes que codificam para as proteínas HRP2 e HRP3 foi realizada em colaboração com a Universidade Peruana Cayetano Heredia em Lima, sob a responsabilidade da Dra. Dionicia Gamboa, responsável pelo desenvolvimento de projetos na área. Todos os isolados foram analisados: A17, 38A, 44A, 94A, KA, Pf03, FMS. 
A amplificação do exon 2 dos genes pfhrp2 e pfhrp3 foi realizada com o uso de 2 $\mathrm{mM} \mathrm{MgCl}$, 0,2 mM de cada dNTP, $75 \mathrm{ng}$ de cada primer, 1,25 U de AmpliTaq Gold (PE Applied Biosystems), e $1 \mu \mathrm{L}$ de DNA, sob as seguintes condições: $94^{\circ} \mathrm{C}$ por $10 \mathrm{~min}$, seguido de 45 ciclos de $\left(50 \mathrm{~s}\right.$ a $94{ }^{\circ} \mathrm{C}, 50 \mathrm{~s}$ a $55^{\circ} \mathrm{C}$ e $1 \mathrm{~min}$ a $\left.70^{\circ} \mathrm{C}\right)$, como descrito por Baker et al. (2005). Três protocolos adicionais de PCR foram utilizados para amplificar exon 1 e 2 de ambos os genes (Gamboa et al., 2010).

\subsection{Detecção dos gene kahrp}

Para verificar se algum dos nossos isolados era knob negativo, nós realizamos a detecção do gene que codifica a proteína KAHRP através de PCR em tempo real. Esta análise foi feita em todos os isolados de campo (38A, 44A, 94A, KA, Pf03, FMS e A17) e também com a cepa 3D7.

Os oligonucleotídeos, utilizados para amplificar um fragmento de 101 pb, apresentavam as seguintes sequências: primer foward 3'CTACACCAGGCGCAAAAGAT 5' e primer reverse 3'TCCTTCAGCAGCACATTGTC 5'.

A amplificação do gene da kahrp foi realizada com o utilização de 7,5 $\mu \mathrm{l}$ de Máxima SYBR Green qPCR $2 \mathrm{x}, 0,5 \mu \mathrm{M}$ de cada primer, $0,5 \mu \mathrm{l}$ de DNA e água para um volume final de $15 \mu \mathrm{l}$. As condições em que a reação foi submetida foram: 35 ciclos de (15 s a $94{ }^{\circ} \mathrm{C}, 30$ s a $54{ }^{\circ} \mathrm{C}$ e $30 \mathrm{~s}$ a $72{ }^{\circ} \mathrm{C}$ ) com aquisição de fluorescência a $72{ }^{\circ} \mathrm{C}$. Após os ciclos de amplificação seguiu-se a curva de Melting, que consistiu de 15 segundos a $95{ }^{\circ} \mathrm{C}, 1$ minuto a $60{ }^{\circ} \mathrm{C}$ e um ciclo de aumento gradual da temperatura de $0,3{ }^{\circ} \mathrm{C} / \mathrm{s}$ até $95{ }^{\circ} \mathrm{C}$ onde permaneceu por 15 segundos, com aquisição de fluorescência. Com a curva padrão constituída por diluições seriadas razão 10 da amostra de DNA do isolado 3D7.

\subsection{Diagnóstico molecular da hemoglobinopatia HbS}

Foi verificada na população de estudo (seção 3.1), a frequência de polimorfismos relacionados à hemoglobinopatia $S$, através da presença de polimorfismos de base única ou SNPs (SNPs do inglês single-nucleotide polymorphisms), cujo alelo rs334(A) codifica a 
cadeia beta da hemoglobina na sua forma normal, e rs334(T) representa o alelo mutado, que em homozigose causa a hemoglobinopatia S ou anemia falciforme.

A deteç̧ão de polimorfismos foi por PCR alelo-específica, sob contrato, pela empresa Prevention Genetics (Estados Unidos). A metodologia empregada foi descrita por Myakishev et al. (2001), que permite a amplificação e a detecção de cada alelo com primers marcados com dois fluoróforos diferentes. O sinal de fluorescência emitido durante o andamento da reação foi captado por fluorimetria para clusterização e posterior identificação dos genótipos (Rusch et al., 2003).

\subsection{Análise estatística}

Testes estatísticos não-paramétricos foram utilizados para a comparação de variáveis contínuas (testes de Mann-Whitney e Wilcoxon) e de variáveis categóricas (teste do qui-quadrado), bem como correlações (teste de correlações de Spearman). Utilizou-se o programa SPSS versão 13.0 (SPSS Inc, Chicago, IL), com nível de significância de 5\% em todos os testes.

\subsection{Aspectos éticos}

Os protocolos de pesquisa desta tese foram analisados e aprovados pela Comissão de Ética em Experimentação com Seres Humanos do ICB da USP (parecer CEP 928 de 2010). 
4 RESULTADOS 


\subsection{Diagnóstico do perfil de adesão dos isolados}

Inicialmente foi feita uma avaliação do perfil de adesão dos isolados para os receptores CD36, ICAM-1 e CSA, utilizando como controle a células CHO-745. Esses ensaios foram feitos primeiramente em frascos de cultivo, de maneira que a quantificação foi realizada através da contagem dos EP (eritrócitos parasitados) aderidos através de fotos tiradas após as lavagens, sendo os resultados expressos em EP/100 células $\mathrm{CHO}$ (Figura 8).

Figura 8 - Primeiro diagnóstico de citoaderência dos sete isolados de campo.

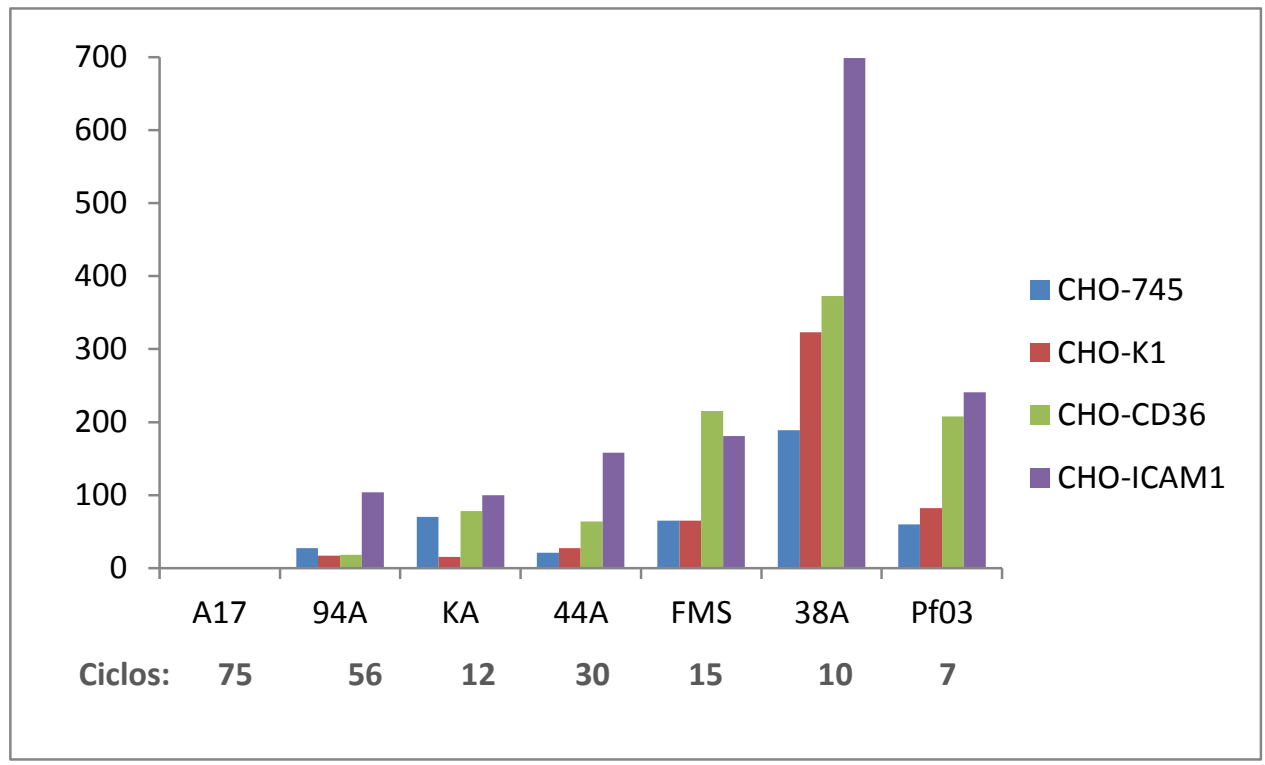

Gráfico de barras ilustrando o perfil de citoaderência inicial de cada isolado de campo, realizados em frascos de cultura de $25 \mathrm{~cm}^{2}$ de superfície. Os valores do eixo das ordenadas representam o número de eritrócitos parasitados (EP)/100 células $\mathrm{CHO}$. O número ciclos indica quantos ciclos de reinvasão passaram desde o descongelamento do isolado até o ensaio de citoaderência.

Posteriormente, foi realizada a caracterização dos isolados com uso de placas $L a b$ Tek. Portanto, refizemos os ensaios de diagnóstico com todos os isolados em triplicatas, como descrito na seção 3.8. A contagem das células foi feita manualmente, em 
microscópio óptico comum (objetiva de 100X), e os resultados expressos em $\mathrm{EP} / \mathrm{mm}^{2}$ (eritrócitos parasitados por milímetro quadrado), como mostram a Tabela 9 e a Figura 9.

Tabela 9 - Diagnóstico de citoaderência.

\begin{tabular}{ccccc}
\hline Isolado & CHO-745 & CHO-K1 & CHO-CD36 & CHO-ICAM-1 \\
\hline \hline A17 & $3 \pm 1$ & $4 \pm 1$ & $17 \pm 3$ & 2 \\
94A & 0 & 0 & 0 & 0 \\
KA & $96 \pm 17$ & $79 \pm 11$ & $150 \pm 11$ & $148 \pm 13$ \\
44A & $6 \pm 2$ & 3 & $8 \pm 2$ & $6 \pm 2$ \\
FMS & $34 \pm 10$ & $33 \pm 5$ & $112 \pm 20$ & $79 \pm 15$ \\
38A & $17 \pm 3$ & $18 \pm 5$ & $39 \pm 3$ & $27 \pm 5$ \\
Pf03 & $45 \pm 2$ & $39 \pm 6$ & $156 \pm 27$ & $149 \pm 28$ \\
\hline
\end{tabular}

Diagnóstico de aderência de sete isolados de campo a receptores expressos em células $\mathrm{CHO} 745, \mathrm{~K} 1, \mathrm{CD} 36 \mathrm{e}$ ICAM-1. Os valores estão expressos em EP/mm², seguidos do desvio padrão.

Os dados desta tabela foram plotados em um gráfico de barras para uma melhor visualização dos resultados (Figura 9) e para uma comparação com os dados do primeiro diagnóstico realizados em frascos de cultura (Figura 8). Em vista dos diferentes métodos de contagem utilizados para as microplacas Lab-Tek para os frascos de cultivo, devemos levar em consideração para fins de comparação, o padrão de aderência e não os valores absolutos. 
Figura 9 - Citoaderência dos sete isolados de campo em diferentes linhagens de CHO.

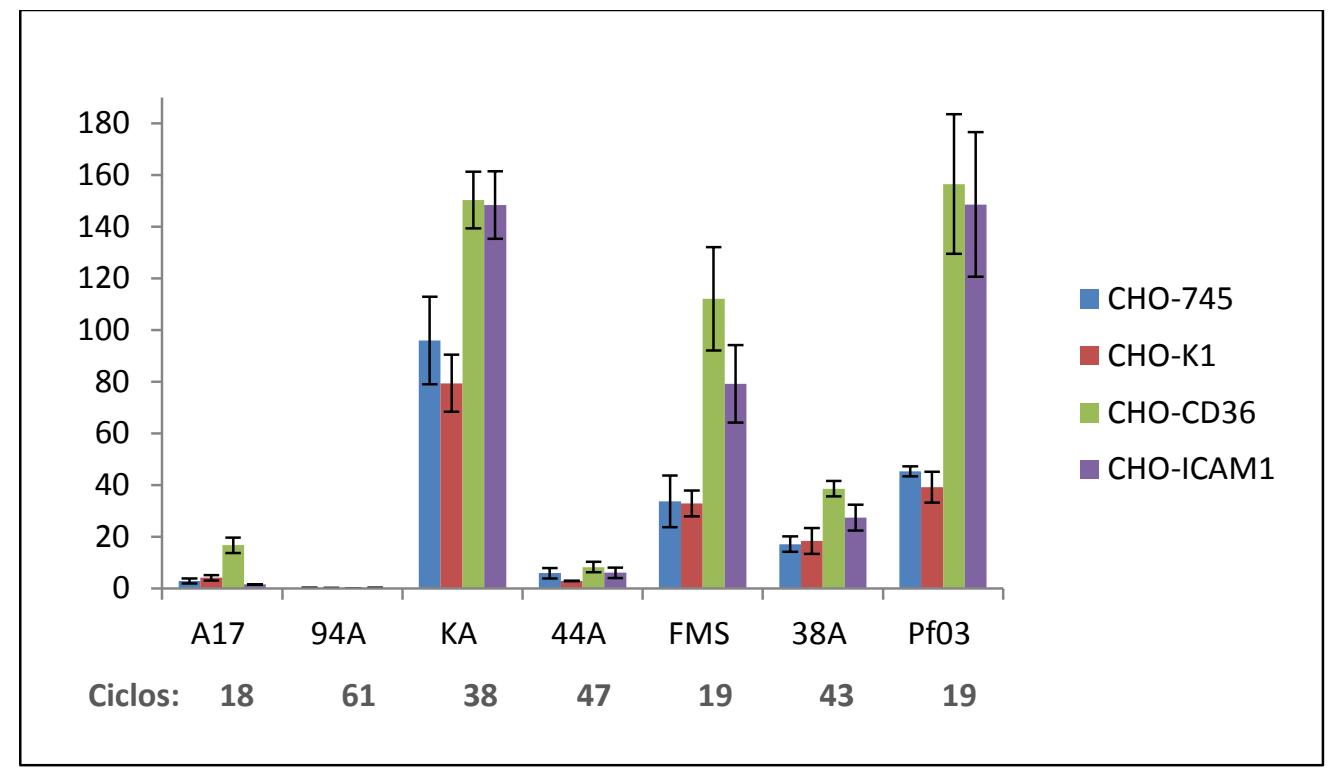

Gráfico de barras ilustrando o perfil de citoaderência inicial de cada isolado de campo. O eixo das ordenadas está expresso em $\mathrm{EP} / \mathrm{mm}^{2}$ de uma superfície de células $\mathrm{CHO}$ específica, agrupadas por isolado. As barras de erros representam o desvio padrão. O número ciclos indica quantos ciclos de reinvasão passaram desde o descongelamento do isolado até o ensaio de citoaderência

Colocando-se lado a lado os dados do primeiro e segundo ensaio de adesão, para cada isolado, temos as Figuras 10A-G. Para uma melhor comparação entre as duas análises quantificadas diferentemente, nós atribuímos o valor " 1 " para o número de eritrócitos infectados aderidos a CHO-745 e, portanto, os valores para os demais receptores representam quantas vezes mais eles grudaram em relação a CHO-745 para cada experimento. 
Figura 10 - Comparação do comportamento de adesão entre o primeiro diagnóstico e segundo diagnóstico de sete isolados de campo.

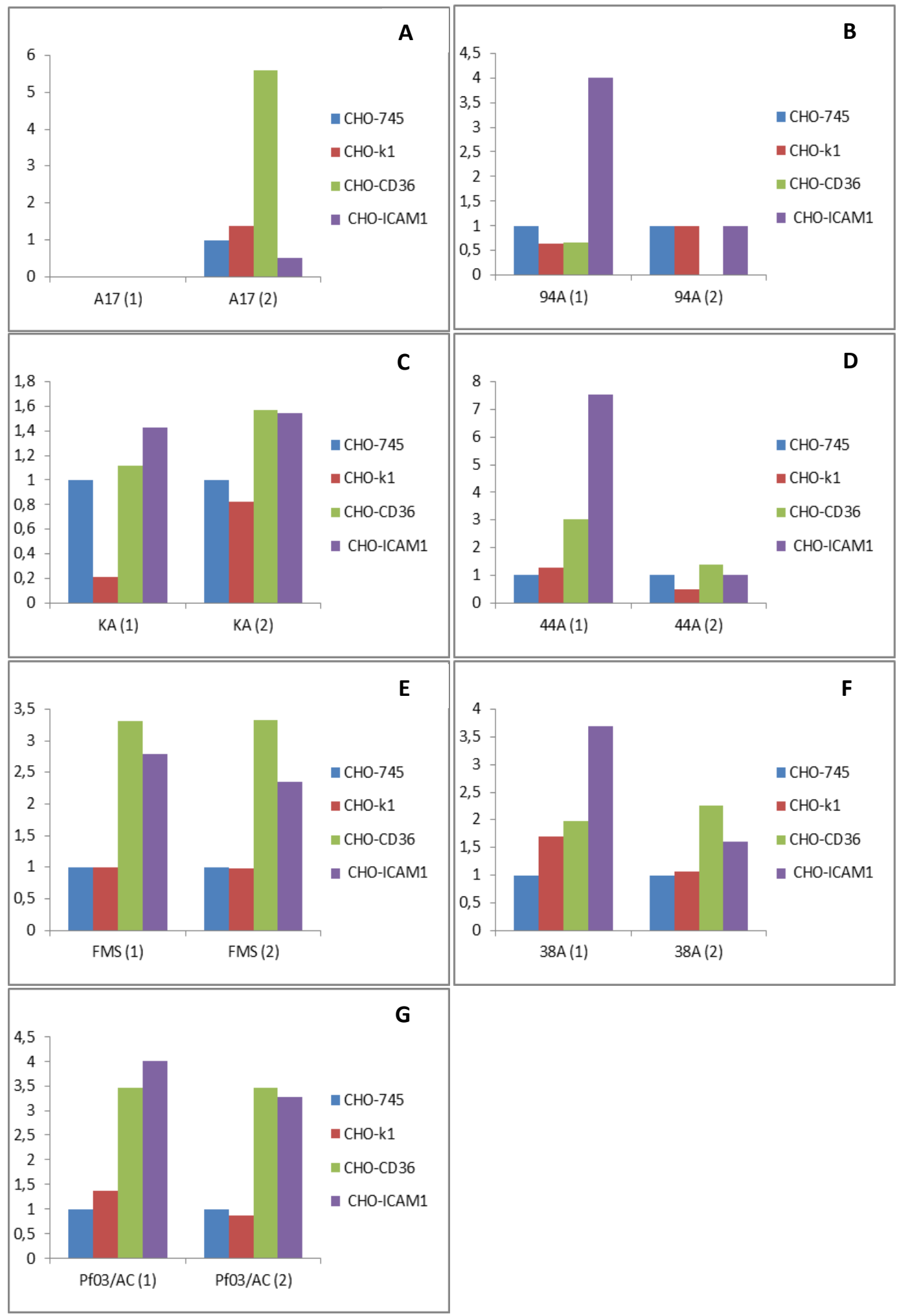

Gráfico de barras comparando o comportamento de adesão entre o primeiro diagnóstico (1) (ensaio em frascos de cultura) e segundo diagnóstico (2) (ensaio em placas Lab-Tek) dos sete isolados de campo: A17 (A), 94A (B), FMS (C), KA (D), 44A (E), 38A (F) e Pf03 (G). 
O dado mais notável desses gráficos é o fato de que a adesão a ICAM-1 parece ser reduzida (Figura 10C e 10E) ou mesmo perdida (Figura 10D e 10F) com o passar do tempo. Todos os isolados que aderiam mais a ICAM-1 tiveram sua capacidade reduzida ao decorrer de alguns ciclos.

Também pudemos notar através do isolado A17, um isolado muito bem adaptado, que o cultivo prolongado e ininterrupto pode levar à perda total da capacidade de adesão a qualquer um dos receptores testados. Considerando aqui, que foram feitas várias tentativas de binding com esse isolado (com longo período de cultivo), obtendo sempre o mesmo resultado negativo.

Mesmo apresentando uma ligeira redução na aderência a ICAM-1, os isolados que sofreram uma menor variação de tempo entre um experimento e outro (FMS e Pf03) apresentaram um perfil semelhante nos dois ensaios, assim como KA, caracterizando um perfil biaderente.

O intuito dessa averiguação inicial era de não apenas caracterizar os isolados, mas também de selecionar candidatos a um perfil monoaderente através da a técnica de panning (seção 3.8.3).

Desde já, descartamos o isolado $94 \mathrm{~A}$ pois os EP contados nas fotos se desprenderam das células espontaneamente, em pouco tempo, quando observamos novamente através da lupa invertida. Este fenômeno não ocorreu com nenhum outro isolado. Além disso, desconfiávamos que se tratasse de parasita knob negativo, pois não era possível concentrar suas formar maduras através do procedimento de floating.

Os isolados 44A e KA também foram descartados por serem mais difíceis de manter em cultura, requerendo maior tempo de cultivo para os experimentos subsequentes, o que poderia acarretar na perda do fenótipo adesivo, como observamos no gráfico 10D.

$\mathrm{O}$ isolado $\mathrm{A} 17$, candidato monoaderente a CD36, logo após o segundo panning, passou a aderir a ambos receptores (Figura 11) e em menor quantidade que os demais.

Tanto FMS como Pf03, mantiveram suas "preferências" inicias mesmo após os cinco procedimentos de panning. FMS permaneceu mais aderente a CD36 e PfO3, mais aderente a ICAM-1 (Figura 11). A seleção de fenótipo por panning se mostrou mais eficiente apenas para o isolado 38A (Figura 11). 
Figura 11 - Análise de citoaderência dos isolados de campo selecionados para CD36 e ICAM-1.

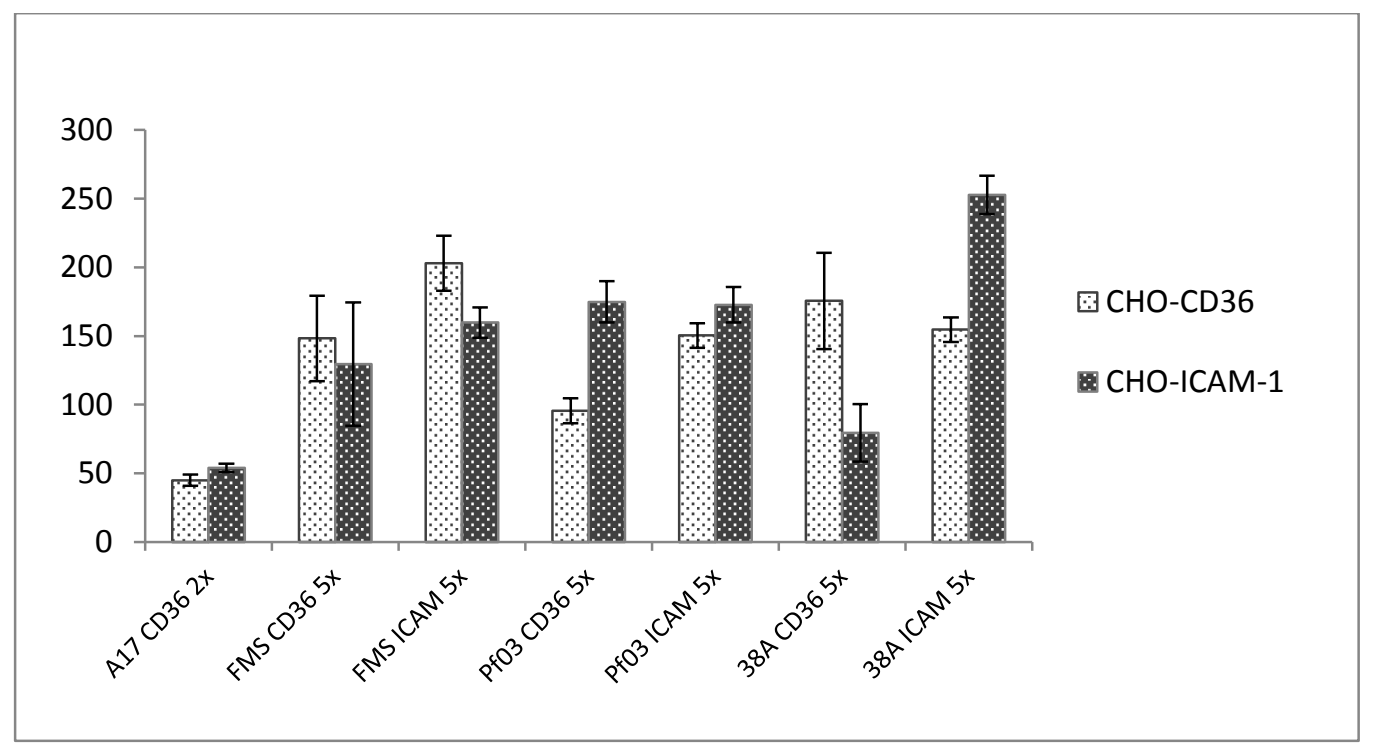

Gráfico mostrando a reavaliação de citoaderência após vários procedimentos de seleção para CD36 eICAM1. $\mathrm{O}$ eixo das ordenadas está expresso em $\mathrm{EP} / \mathrm{mm}^{2}$ aderidos a uma superfície de células $\mathrm{CHO}$ específica (CD36 em branco e ICAM-1 em preto). As barras de erros representam o desvio padrão de experimentos em triplicatas.

A figura seguinte compara os resultados obtidos no experimento anterior (Figura 11, em que foram testadas a aderência de isolados selecionados por citoaderência) com os resultados do diagnóstico. Todos os ensaios seguiram a mesma metodologia. 
Figura 12 - Comparação do perfil de adesão inicial e pós-seleção.
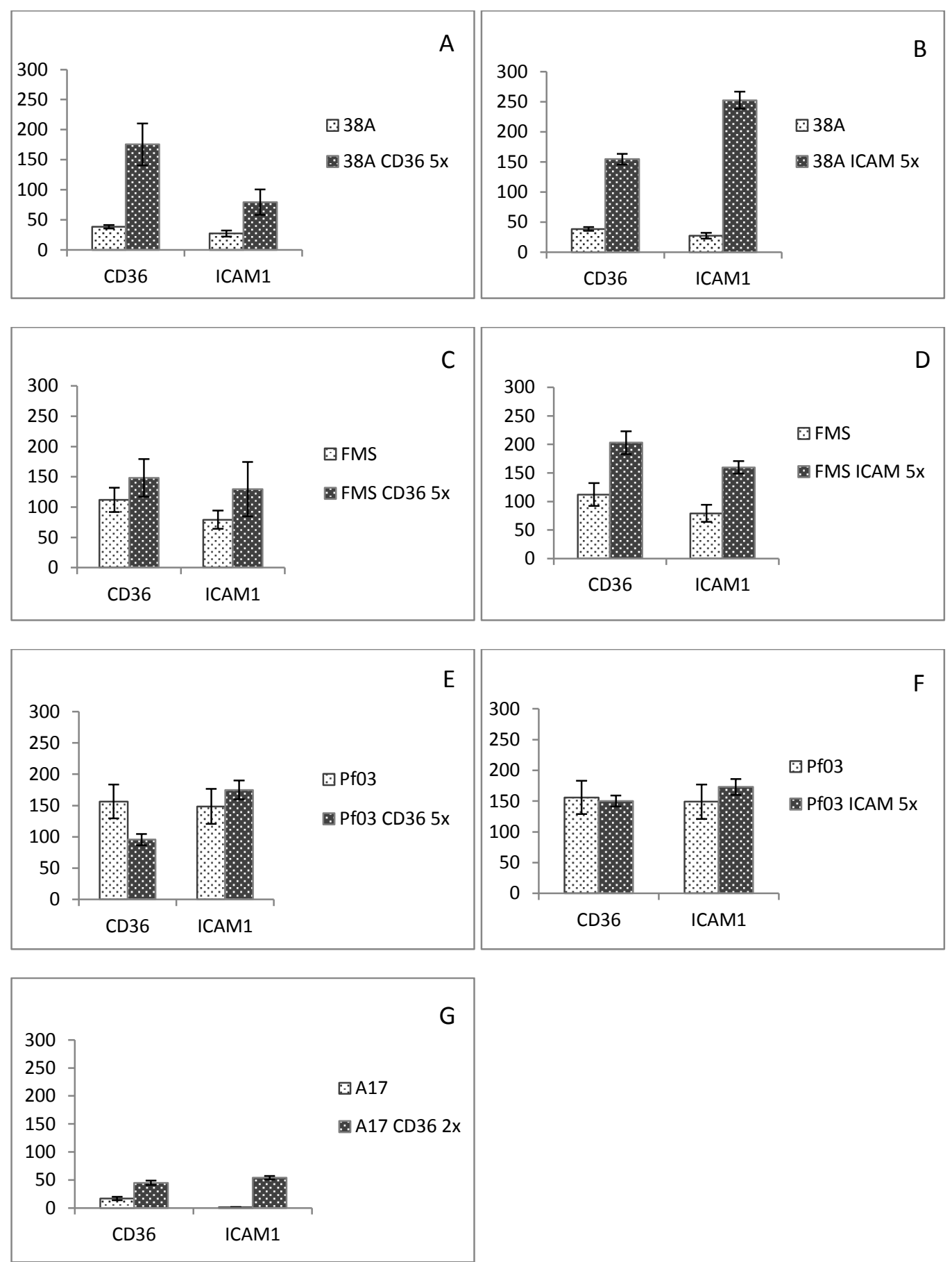

Gráfico comparando o perfil de adesão inicial aos receptores CD36 e ICAM-1 (barras claras) e o perfil de adesão após seleção por panning (barras escuras), ou seja, união das figuras 8 e 11 para isolados de campo: 38A (A e B), FMS (C e D), Pf03 (E e F) e A17 (G). As barras de erros representam o desvio padrão. 


\subsection{Citoaderência a HLEC em condições estáticas}

Os isolados $\mathrm{FMS}^{\mathrm{CD} 36}$, $\mathrm{FMS}^{\mathrm{ICAM}}$, $\mathrm{PfO}^{\mathrm{CD} 36}$, $\mathrm{PfO}^{\mathrm{ICAM}}, 38 \mathrm{~A}^{\mathrm{CD} 36}$ também foram testados quanto a sua aderência em células HLEC. Como se trata de um tipo celular que expressa tanto CD36 como ICAM-1, este último em maior quantidade, utilizamos anticorpos específicos para bloquear um e outro receptor. Desta forma, a avaliação é feita através da diferença entre o valor do controle sem presença anticorpo e o valor do anticorpo específico. Essa diferencia irá nos estimar a adesão fenótipo específica que o anticorpo bloqueou, ou seja, o quanto aquele isolado foi capaz de aderir especificamente àquele receptor.

Figura 13 - Citoaderência do isolado FMS ${ }^{\mathrm{CD} 36}$ e FMS ICAM em células HLEC.

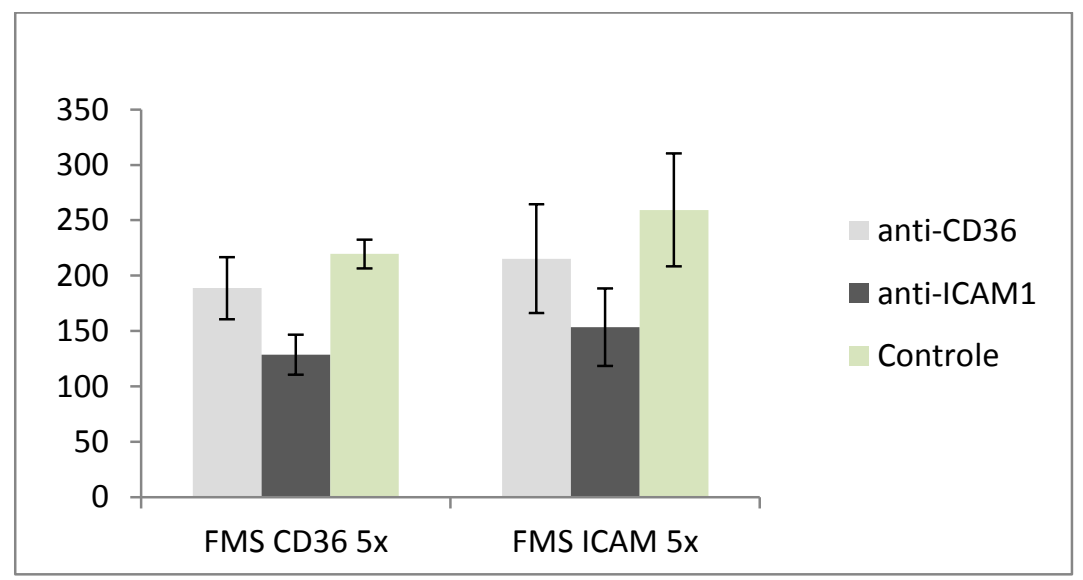

Gráfico ilustrando o perfil de adesão do isolado $\mathrm{FMS}^{\mathrm{CD} 36}$ e $\mathrm{FMS}^{\mathrm{ICAM}}$ a células HLEC. O eixo das ordenadas está expresso em EP/mm² da superfície células HLEC com adição de anticorpo (em cinza claro e escuro) e sem adição de anticorpo (em verde claro). As barras de erros representam o desvio padrão.

Assim como observamos na Figura 11 , o perfil de aderência entre FMS $^{\mathrm{CD} 36}$ e FMS $^{\text {ICAM }}$ foi bastante parecido, apresentando um perfil biaderente. Considerando que haja uma maior expressão de ICAM-1 nas HLEC, isso explica porque a mesma quantidade de anticorpo provoca um efeito diferente em isolados biaderentes, uma vez que o anti-CD36 possa ter atingido saturação, bloqueando " $x$ " receptores CD36, enquanto que e a mesma quantidade de anti-ICAM1 bloqueou "1,5 x" receptores ICAM-1.

O mesmo foi observado para os isolados $38 \mathrm{~A}^{\mathrm{CD} 36}$, $\mathrm{PfO}^{\mathrm{CD} 36}$ e $\mathrm{PfO}^{\mathrm{ICAM}}$ (Figuras 14 e 15). 
Figura 14 - Citoaderência do isolado $38 \mathrm{~A}^{\mathrm{CD} 36}$ em HLEC.

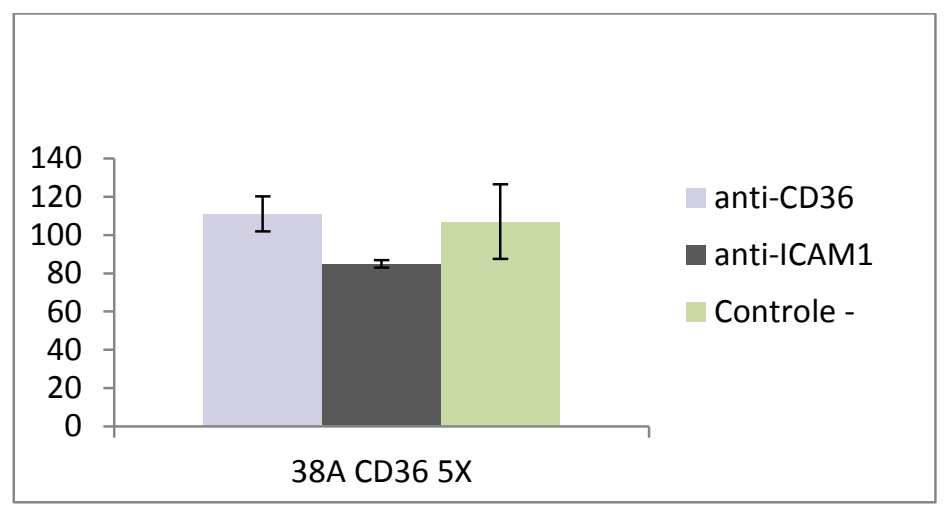

Gráfico ilustrando o perfil de adesão do isolado $38 \mathrm{~A}^{\mathrm{CD} 36}$ a células HLEC. O eixo das ordenadas está expresso em EP/mm² da superfície células HLEC com adição de anticorpo (em cinza claro e escuro) e sem adição de anticorpo (em verde claro). As barras de erros representam o desvio padrão.

Para verificar a eficácia dos anticorpos, adicionamos um controle duplo positivo (adição dos dois anticorpos ao mesmo tempo) na avaliação de $\mathrm{PfO}^{\mathrm{CD} 36}$ e $\mathrm{PfO}^{\text {ICAM }}$ (Figura 15).

Figura 15 - Citoaderência do isolado $\mathrm{PfO}^{\mathrm{CD} 36}$ e PfO3 ${ }^{\mathrm{ICAM}}$ em HLEC.

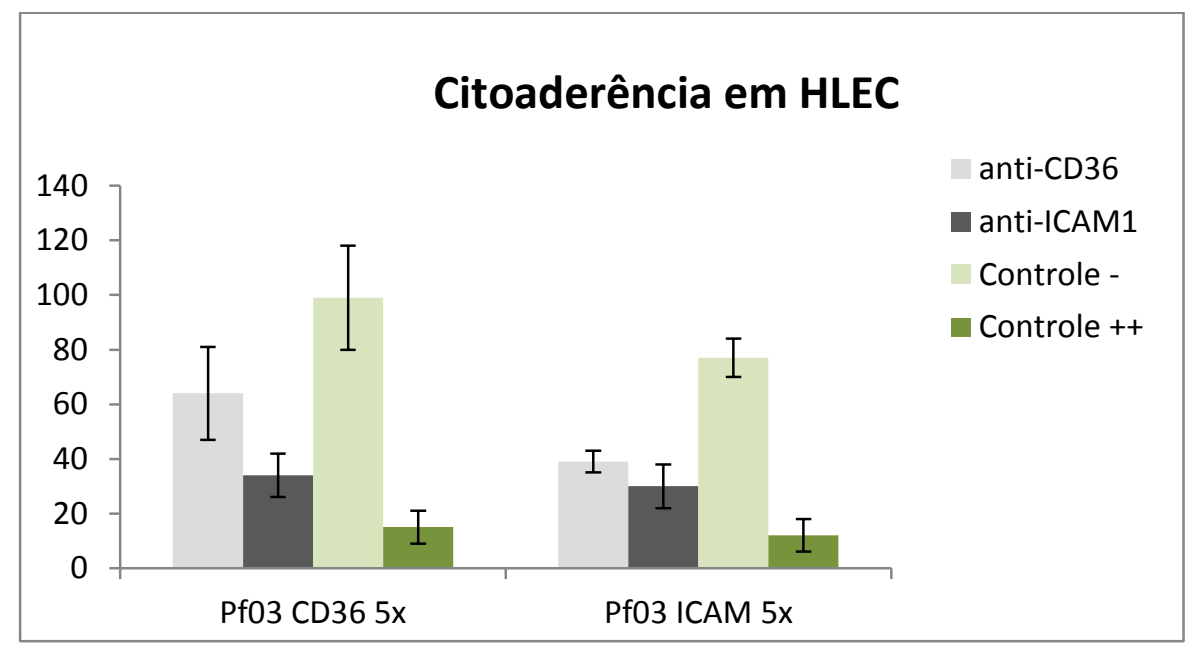

Gráfico ilustrando o perfil de adesão do isolado $\mathrm{PfO}^{\mathrm{CD} 36}$ e $\mathrm{PfO3}^{\mathrm{ICAM}}$ a células HLEC. O eixo das ordenadas está expresso em $\mathrm{EP} / \mathrm{mm}^{2}$ da superfície células HLEC com adição de cada anticorpo separadamente (em cinza claro e escuro), controle sem adição de anticorpo (em verde claro) e controle com adição de ambos anticorpos (Controle ++ em verde escuro). As barras de erros representam o desvio padrão. 


\subsection{Citoaderência a HLEC sob condições de fluxo}

Os ensaios de citoaderência em fluxo mimetizam melhor a situação fisiológica por aplicar uma forca definida de atrito. Estes ensaios foram realizados para os seguintes isolados: $\mathrm{FMS}^{\mathrm{CD} 36}$, $\mathrm{FMS}^{\mathrm{ICAM}}, 38 \mathrm{~A}^{\mathrm{CD} 36}$ e $38 \mathrm{~A}^{\mathrm{ICAM}}$.

Os ensaios de "Desprendimento em fluxo" (Figura 16, gráficos à esquerda) expressam a capacidade dos isolados, uma vez aderidos estaticamente, permanecerem aderidos após a passagem de três intensidades de fluxo distintas: fluxo 1 com 0,31

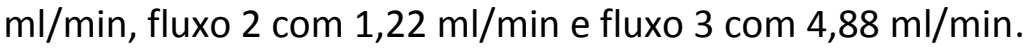

Os ensaios de "Adesão" (Figura 18, gráficos à direita) expressam a capacidade dos isolados aderirem às células durante o fluxo, ou seja, sob condições mais parecidas ao que ocorre in vivo. Para este ensaio utilizou-se uma pressão de 0,09 Pa por 10 minutos $(0,31 \mathrm{ml} / \mathrm{min})$.

Para expressar os valores contados nas fotos em gráficos, consideramos como 100\% a média dos EP contados nas fotos antes do fluxo (adesão estática), considerada como o máximo de adesão para ambos experimentos. 
Figura 16 - Citoaderência em HLEC sob condições de fluxo.

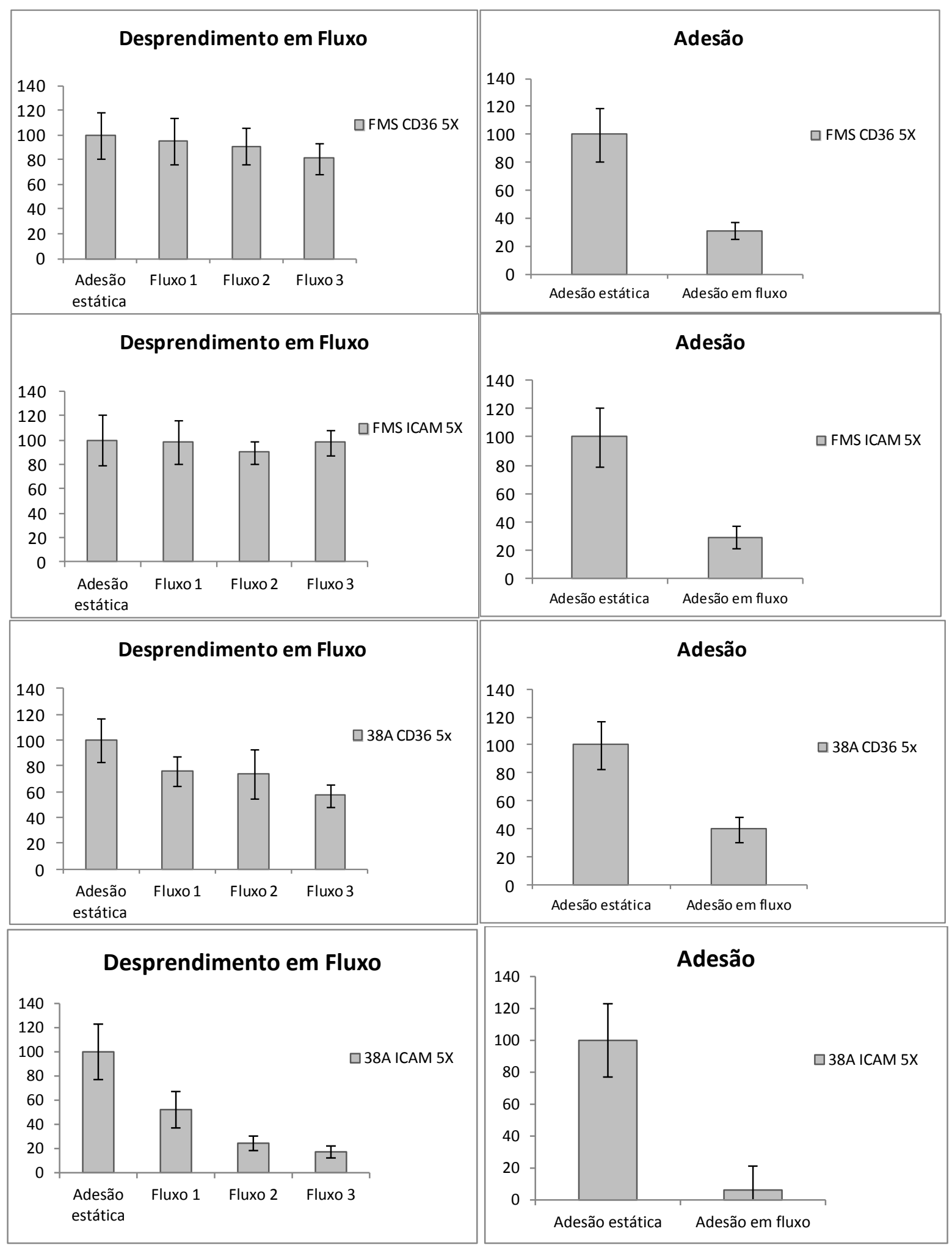

Ensaios de desprendimento e adesão em fluxo dos isolados $\mathrm{FMS}^{\mathrm{CD} 36}$, FMS $\mathrm{FMM}^{\mathrm{ICAM}}, 38 \mathrm{~A}^{\mathrm{CD} 36} \mathrm{e} 38 \mathrm{~A}^{\mathrm{ICAM}}$ a células HLEC. O eixo das ordenadas representa a porcentagem de hemácias infectadas aderidas nas células HLEC. As barras de erros representam o desvio padrão entre as fotos. 
Além dos gráficos, apresentamos também aqui uma foto representativa de cada um dos momentos dos ensaios (Figura 17A-E, 18A-E, 19A-E, 20A-E). Pudemos notar que o isolado FMS ${ }^{\text {CD36/ICAM }}$, principalmente FMS ICAM possuiu um padrão de adesão com frequente formação de pequenos aglomerados de EP (apontado por setas), o que não aconteceu ou raramente aconteceu com os outros isolados.

Figura 17 - Experimentos de adesão e desprendimento em condições de fluxo de FMS ICAM.
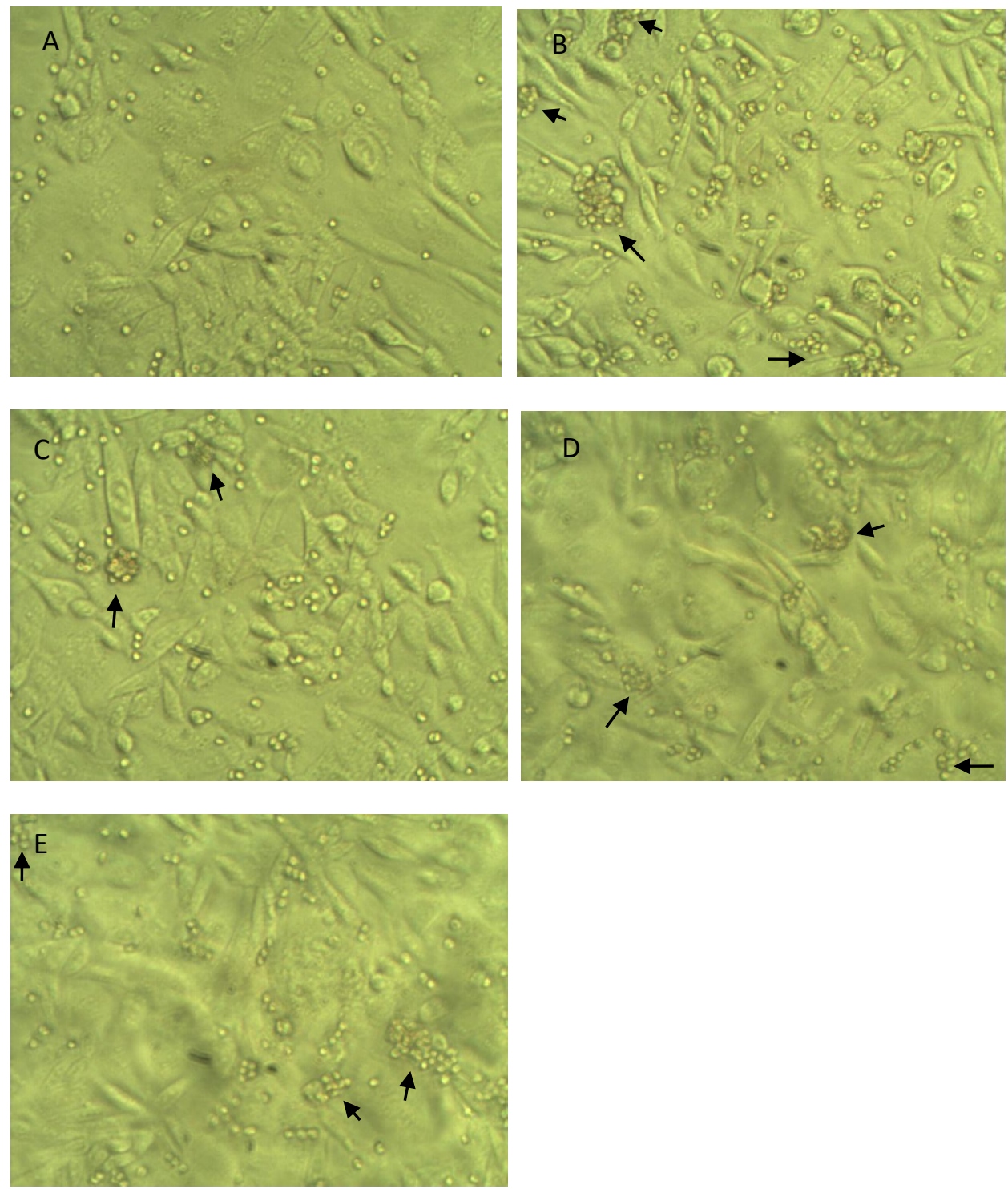

Ensaio de adesão (A). Ensaio de desprendimento: antes do início do fluxo (B), após fluxo 1 (C), após fluxo 2 (D), após fluxo 3(E). As setas indicam pontos de aglomerado de hemácias parasitadas. 
Figura 18 - Experimentos de adesão e desprendimento em condições de fluxo de FMS ${ }^{\mathrm{CD} 36}$.
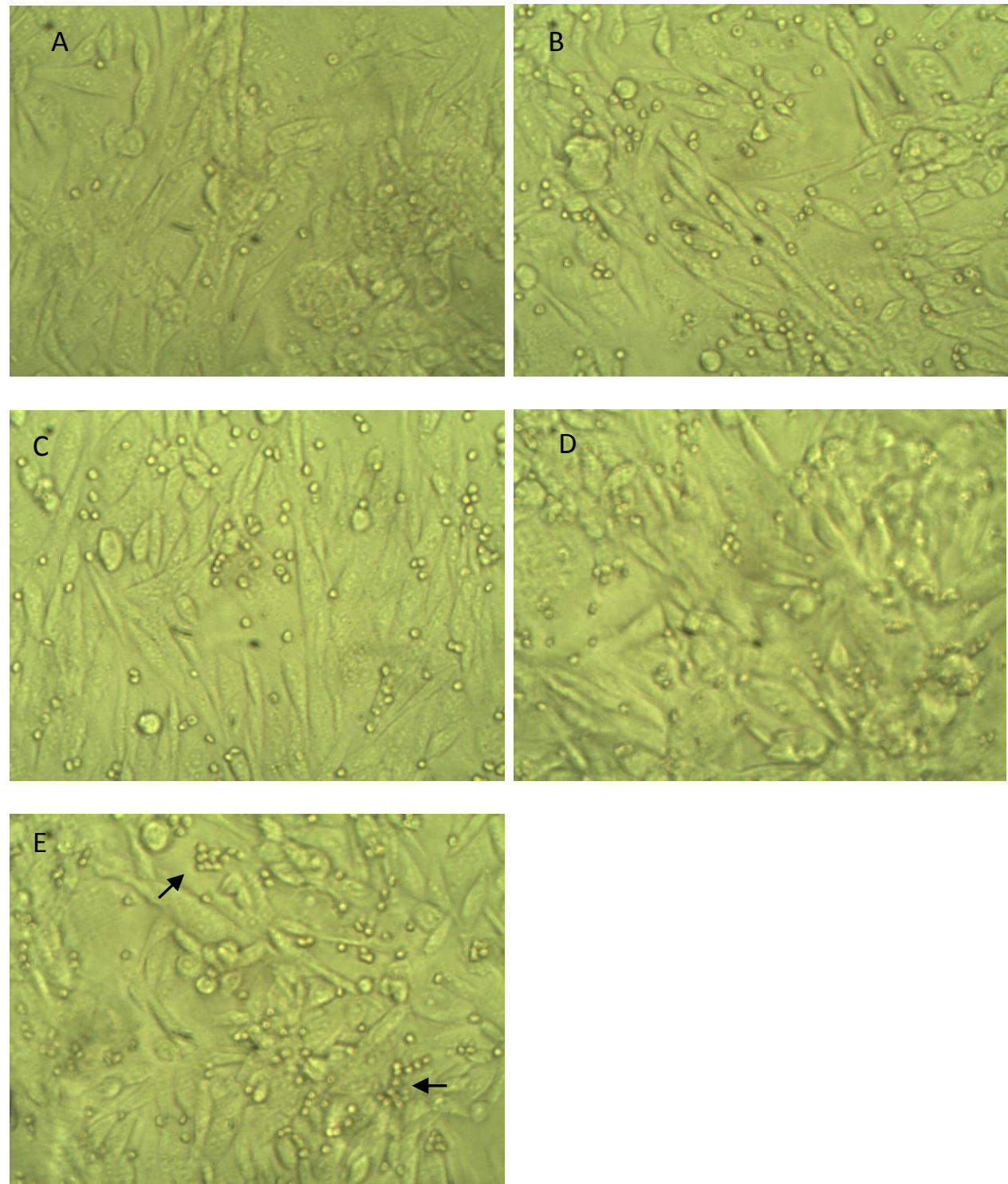

Ensaio de adesão (A). Ensaio de desprendimento: antes do início do fluxo (B), após fluxo 1 (C), após fluxo 2 (D), após fluxo 3(E). As setas indicam pontos de aglomerado de hemácias parasitadas. 
Figura 19 - Experimentos de adesão e desprendimento em condições de fluxo de $38 \mathrm{~A}^{\mathrm{CD} 36}$.
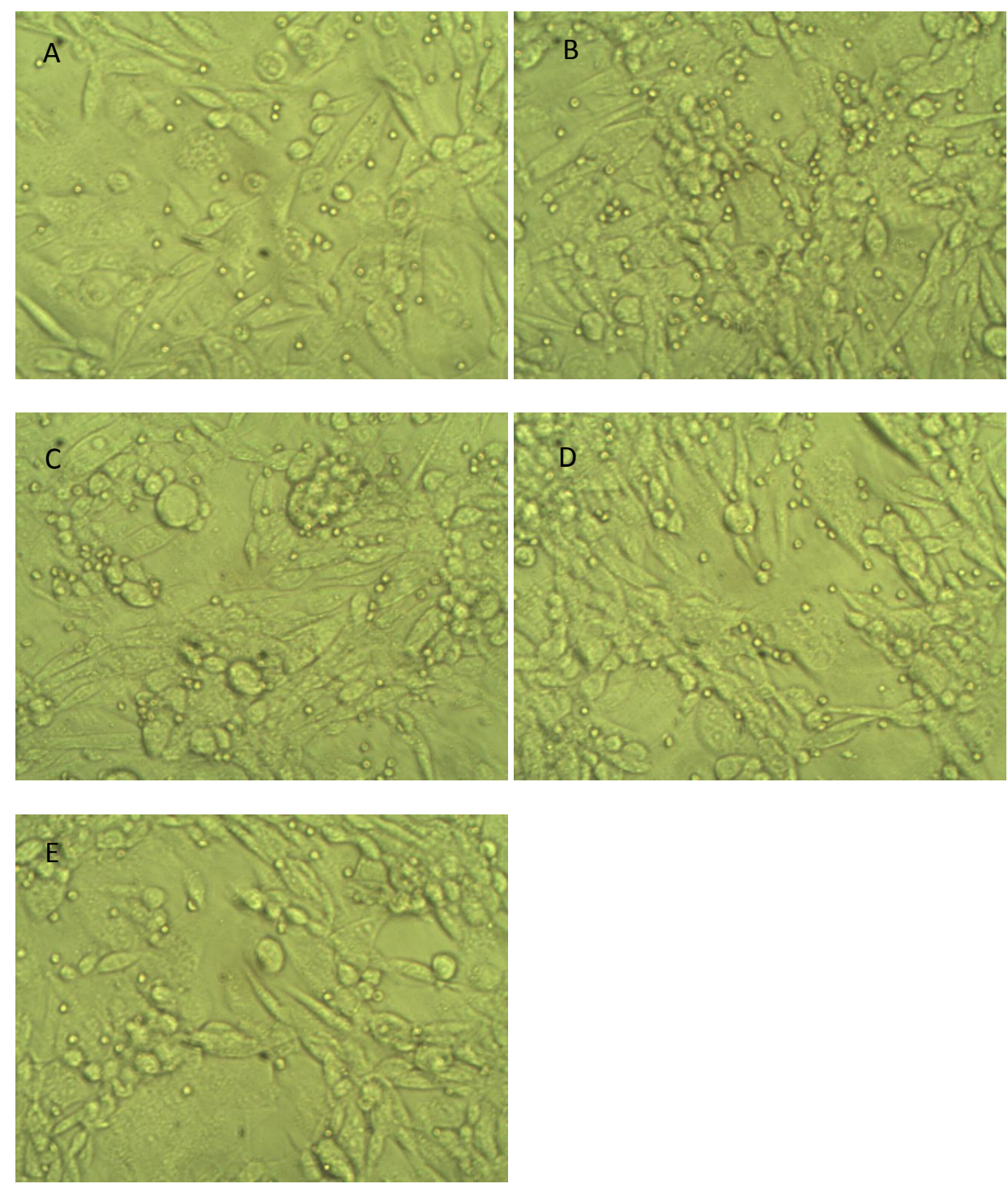

Ensaio de adesão (A). Ensaio de desprendimento: antes do início do fluxo (B), após fluxo 1 (C), após fluxo 2 (D), após fluxo 3(E). 
Figura 20 - Experimentos de adesão e desprendimento em condições de fluxo de 38A ICAM .
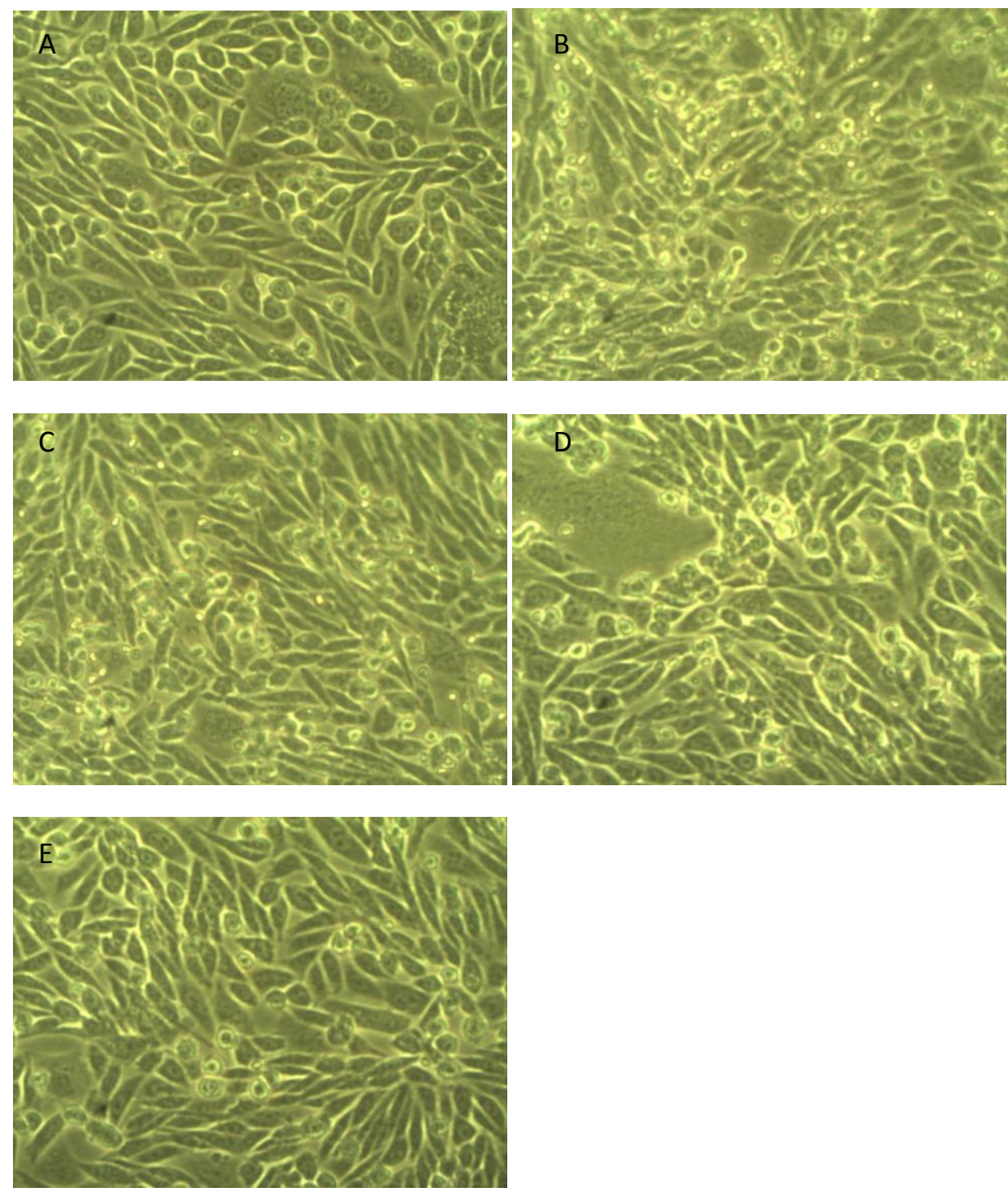

Ensaio de adesão (A). Ensaio de desprendimento: antes do início do fluxo (B), após fluxo 1 (C), após fluxo 2 (D), após fluxo 3(E).

Para verificar se algumas das variações fenotípicas observadas poderiam ser devidas à presença de mais de um clone em nossas amostras, presença ou ausência de knob, também realizamos análises moleculares para verificar a clonalidade dos isolados por microssatélites e a possível deleção dos genes hrp2, hrp3 e kahrp por PCR convencional e PCR em tempo real. 


\subsection{Análise da deleção de hrp2 e hrp3}

Para excluir que eventuais polimorfismos nos genes hrp2 e 3 impossibilitariam uma detecção por PCR, também foi verificada a presença ou ausência dos seus genes adjacentes, descritos brevemente na Tabela 10.

Tabela 10 - Descrição, localização e tamanho dos genes adjacentes ao hrp2 e hrp3.

\begin{tabular}{cccc}
\hline Gene HRP2 & Descrição & Posição relativa ao gene HRP2 & Distância (kb) \\
\hline \hline MAL7P228 & Gene flanqueador & Upstream & $6.4 \mathrm{~kb}$ \\
MAL7P230 & Gene flanqueador & Downstream & $5.5 \mathrm{~kb}$ \\
\hline & & & \\
\hline Gene HRP3 & Descrição & Posição relativa ao gene HRP3 & Distância (kb) \\
\hline \hline MAL13P475 & Gene flanqueador & Upstream & $1.68 \mathrm{~kb}$ \\
MAL13P485 & Gene flanqueador & Downstream & $4.4 \mathrm{~kb}$ \\
\hline
\end{tabular}

Tabela 11 - Resultados do exame de deleção dos genes hrp2 e hrp3 e seus genes adjacentes.

\begin{tabular}{|c|c|c|c|c|c|c|}
\hline Amostras & & & & & \\
& MAL7P228 & HRP2 & MAL7P230 & MAL13P475 & HRP3 & MAL13P485 \\
\hline FMS & + & + & + & + & + & + \\
\hline KA & - & + & + & + & + & + \\
\hline PF03 & + & + & + & + & + & + \\
\hline A17 & + & + & + & + & + & + \\
\hline 44A & + & + & + & + & + & + \\
\hline 94A & + & + & + & + & + & + \\
\hline 38A & + & + & + & + & + & + \\
\hline
\end{tabular}

Representamos como (+) a presença do gene e (-) a sua ausência.

\subsection{Análise da deleção de kahrp}

A análise molecular dos genes $h r p 2$ e $h r p 3$, realizada anteriormente, não evidenciou deleção dos genes em nenhum dos isolados em estudo. Portanto, para complementar esta análise, verificamos, a presença ou ausência do gene da kahrp, já descrito codificar uma proteína de extrema importância para a formação do knob nos eritrócitos infectados (Crabb et al., 1997; Waller et al., 1999). 
Todos os isolados provenientes da Amazônia foram testados por PCR em tempo real, incluindo uma amostra da linhagem 3D7.

Exceto o isolado 94A, todos os demais apresentaram CT significativo, evidenciando a existência do gene kahrp (Figura 23 e Tabela 12). As variações dos valores de $C_{T}$ são devido às diferentes concentrações de DNA genômico de cada amostra de isolado.

Figura 21 - PCR em tempo real para detecção do gene kahrp.

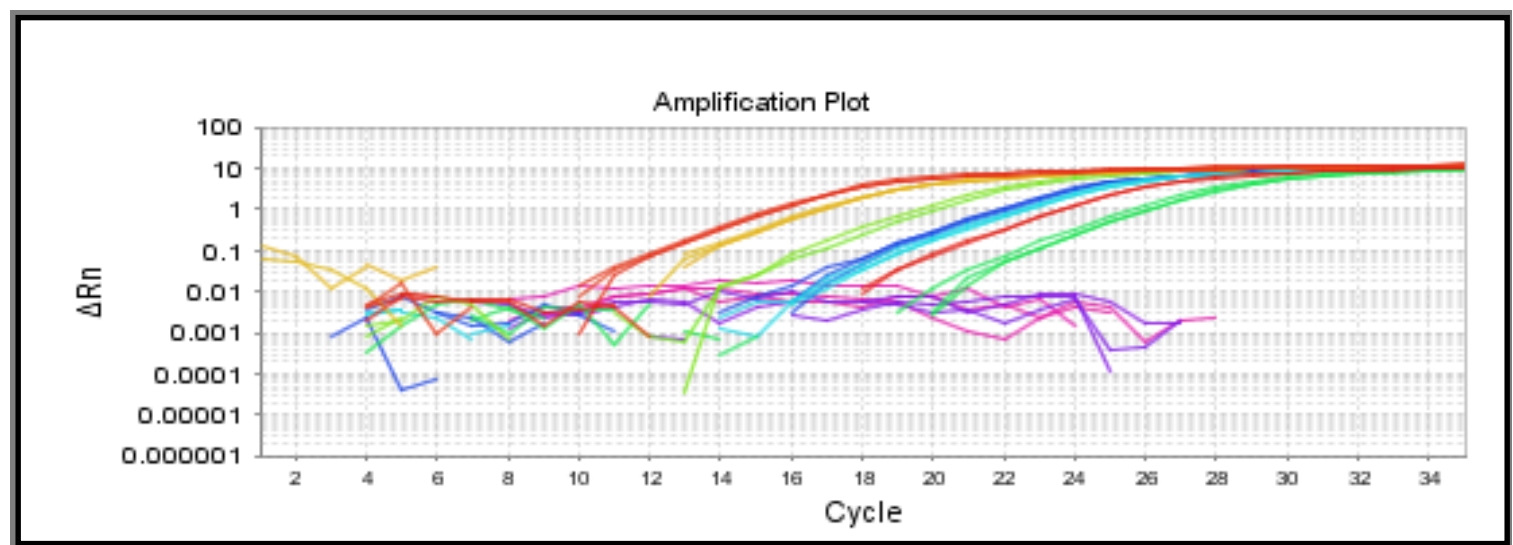

Variação do Rn (normalized reporter) por ciclo de qPCR dos isolados de $P$. falciparum. Todas as amostras foram positivas, exceto $94 \mathrm{~A}$ (em roxo) e controle sem DNA (rosa).

Tabela 12 - Valores e média do $C_{T}$ das triplicatas dos isolados de $P$. falciparum.

\begin{tabular}{cccccccccc}
\hline Isolado & 3D7 & FMS & Pf03 & 44A & 38A & A17 & KA & 94A & Água \\
\hline \hline & & & & & & & & & \\
Cт 1 & 14,19 & 15,45 & 18,13 & 20,40 & 21,19 & 20,79 & 24,68 & Indeterminado & Indeterminado \\
Ст 2 & 14,01 & 15,18 & 19,37 & 20,61 & 21,15 & 22,26 & 24,27 & Indeterminado & Indeterminado \\
Cт 3 & 14,19 & 15,44 & 18,64 & 20,46 & 20,91 & 22,16 & 24,70 & Indeterminado & Indeterminado \\
Média C & $\mathbf{1 4 , 1 3}$ & $\mathbf{1 5 , 3 6}$ & $\mathbf{1 8 , 7 1}$ & $\mathbf{2 0 , 4 9}$ & $\mathbf{2 1 , 0 8}$ & $\mathbf{2 1 , 7 4}$ & $\mathbf{2 4 , 5 5}$ & Indeterminado & Indeterminado \\
\hline
\end{tabular}

Experimentos anteriores já demonstravam características fenotípicas diferentes do isolado 94A, no que se referia à capacidade de concentrar as formas maduras por 
floating, ou seja, por diferença de densidade devido à presença dos knobs na superfície das hemácias infectadas.

A suspeita de que o 94A era um isolado incapaz de formar knobs foi confirmada através de PCR em tempo real, onde não foi possível detectar amplificação do gene em questão. Considerando que a mesma amostra de DNA foi utilizada para as análises de microssatélite, descartamos a possibilidade do resultado negativo ser consequência de uma falha na extração de DNA.

\subsection{Análise da clonalidade dos isolados por microssatélites}

Para a análise de microssatélites, tanto os isolados originais quanto os selecionados foram submetidos ao teste, utilizando-se 10 primers, como descritos na seção 3.17. Os resultados não detectaram a presença significativa de mais de um pico em nenhuma das amostras e portanto, descartamos a possibilidade da existência de mais de um clone por isolado.

Uma vez que as variações fenotípicas observadas não poderiam ser devido à presença de múltiplos clones, focamos na análise da expressão dos receptores CD36 e ICAM-1 das células $\mathrm{CHO}$, através de três metodologias.

\subsection{Western blot das células $\mathrm{CHO}$}

O western blot foi realizado, como descrito na seção 3.10, com lisado de duas alíquotas de células CHO-CD36 e de CHO-ICAM-1. Apenas uma das alíquotas de CHOICAM1 revelou a presença de proteína, como mostrado na Figura 22. 
Figura 22 - Filme fotográfico do western blot das células $\mathrm{CHO}$.

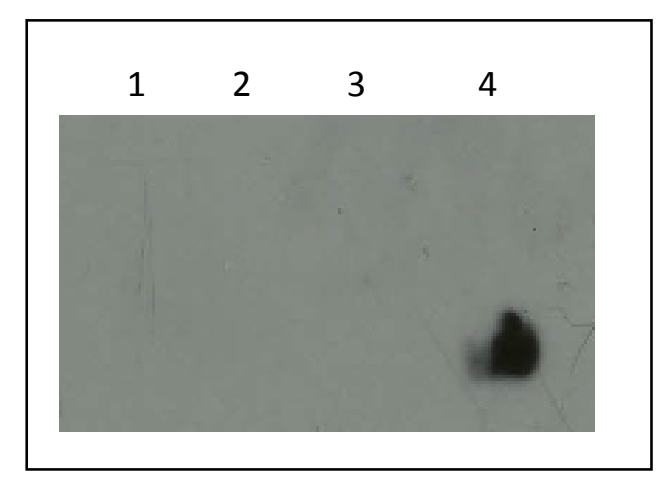

Os algarismos 1 e 2 representam duas alíquotas com lisado de células CHO-CD36 detectados por anti-CD36, e 3 e 4 representam lisados de células CHO-ICAM1, detectados por anti-ICAM1. A banda apresenta na linha 4 possui aproximadamente $57 \mathrm{kDa}$.

É possível que a concentração de anticorpos utilizada tenha sido baixa para CD36. Esse experimento precisaria ser repetido com a adição de um controle positivo e, talvez, com uma maior concentração de anticorpo anti-CD36. Nós pretendíamos repetir o experimento utilizando células $3 T$ e $3 \mathrm{~L} 1$, células diferenciadas em adipócitos que sabidamente expressam CD36, mas não foi possível a obtenção das mesmas e portamos realizamos outra técnica para detecção dos receptores.

\subsection{Expressão de CD36 e ICAM-1 por citometria de fluxo}

A citometria de fluxo das células $\mathrm{CHO}$ foi realizada como descrito na seção 3.11, e mais uma vez, não conseguimos detectar o receptor CD36 nas células CHO nas condições aplicadas.

Aproximadamente 10\% dos 19000 eventos detectaram fluorescência para as células CHO-ICAM1, como mostra a Figura 23. 
Figura 23 - Citometria de fluxo das células CHO-ICAM1.

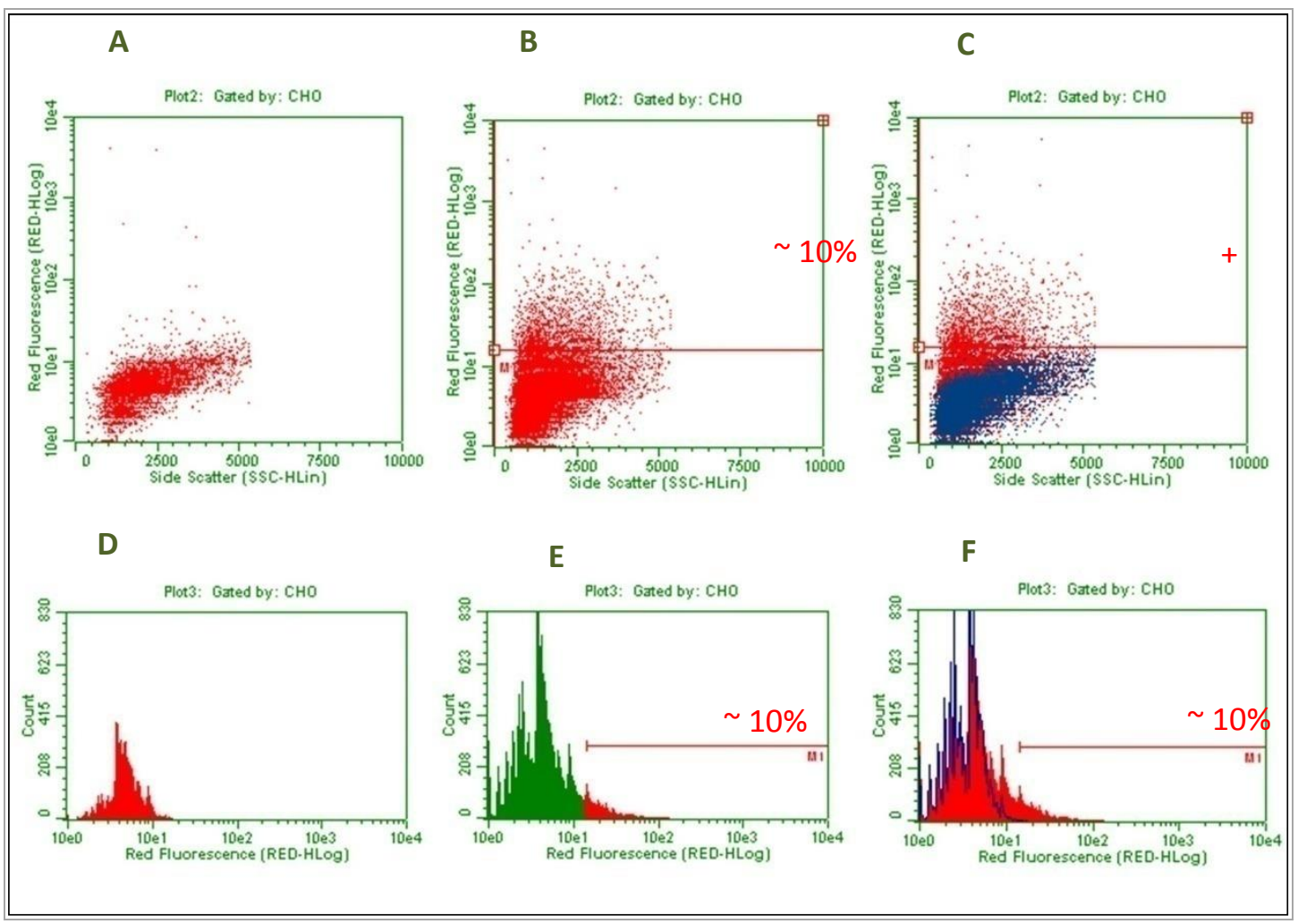

As letras A, B e C representam respectivamente: o dot plot do controle para fluorescência com anticorpo não relacionado; dot plot das células incubadas com anticorpo anti-ICAM1, e dot plot do controle sobreposto ao experimental, respectivamente. As letras D, E e F representam o histograma do controle com anticorpo não relacionado, histograma da amostra experimental com anticorpo anti-ICAM1, e do controle sobreposto ao experimental, respectivamente. A fluorescência vermelha refere-se à captação do anticorpo anti-mouse AlexaFluor 594, utilizado tanto na amostra experimental quanto no controle.

Para melhorar a definição da cultura de células, realizamos um sorting das células $\mathrm{CHO}$, selecionando e recuperando apenas aquelas que expressam seus receptores. Essas células foram devolvidas à cultura, e expandidas e reanalisadas. 
Figura 24 - Citometria de fluxo das células CHO-CD36 pós-sorting.

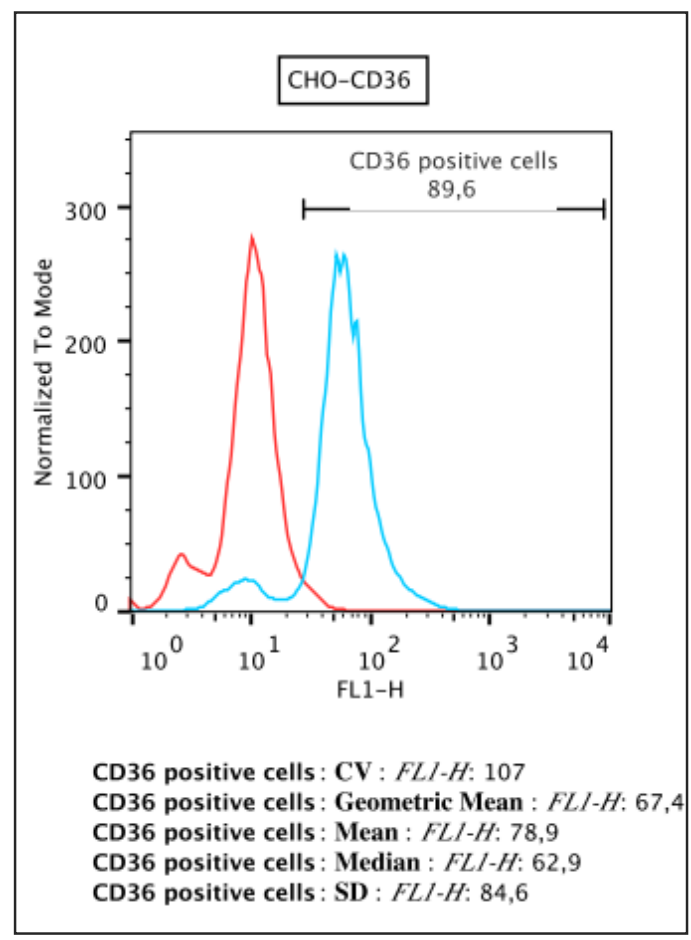

Histograma do controle negativo (linha vermelho) sobreposto às células CHO-CD36 pós-sorting.

O procedimento de cell-sorting foi realizado no laboratório do CEFAP (Centro de facilidades para pesquisa) da USP, utilizando o FACS ARIA III, que é capaz de separar populações celulares em ambiente asséptico, com alto grau de pureza. E a reavaliação da expressão dessas células após sua expansão foi realizado pela Stefanie Costa Pinto Lopes, pós-doutoranda do Laboratório de Imunoparasitologia Experimental (LIPEX) situado no Instituto de Biologia da UNICAMP, sob a responsabilidade do professor Dr. Fábio Trindade M. Costa.

Desta forma, como as células puderam ser bem selecionadas, podemos concluir que havia sim a expressão de CD36 em sua superfície. Ainda assim, utilizamos mais uma metodologia para detectar a presenças dos receptores em $\mathrm{CHO}$. 


\subsection{Análise da expressão de CD36 e ICAM-1 nas células CHO por imunofluorescência}

Como último recurso para demonstrar a expressão dos receptores de superfície das células $\mathrm{CHO}$, foram realizados ensaios de imunofluorescência, com a utilização dos anticorpos primários, anti-CD36/ICAM1, em uma diluição de 1:200.

Em nosso primeiro ensaio, detectamos a presença de ICAM-1 nas células (Figura 25E e 25F), mas não detectamos CD36 sob mas mesmas condições.

Figura 25 - Imunofluorescência das células CHO-ICAM1.

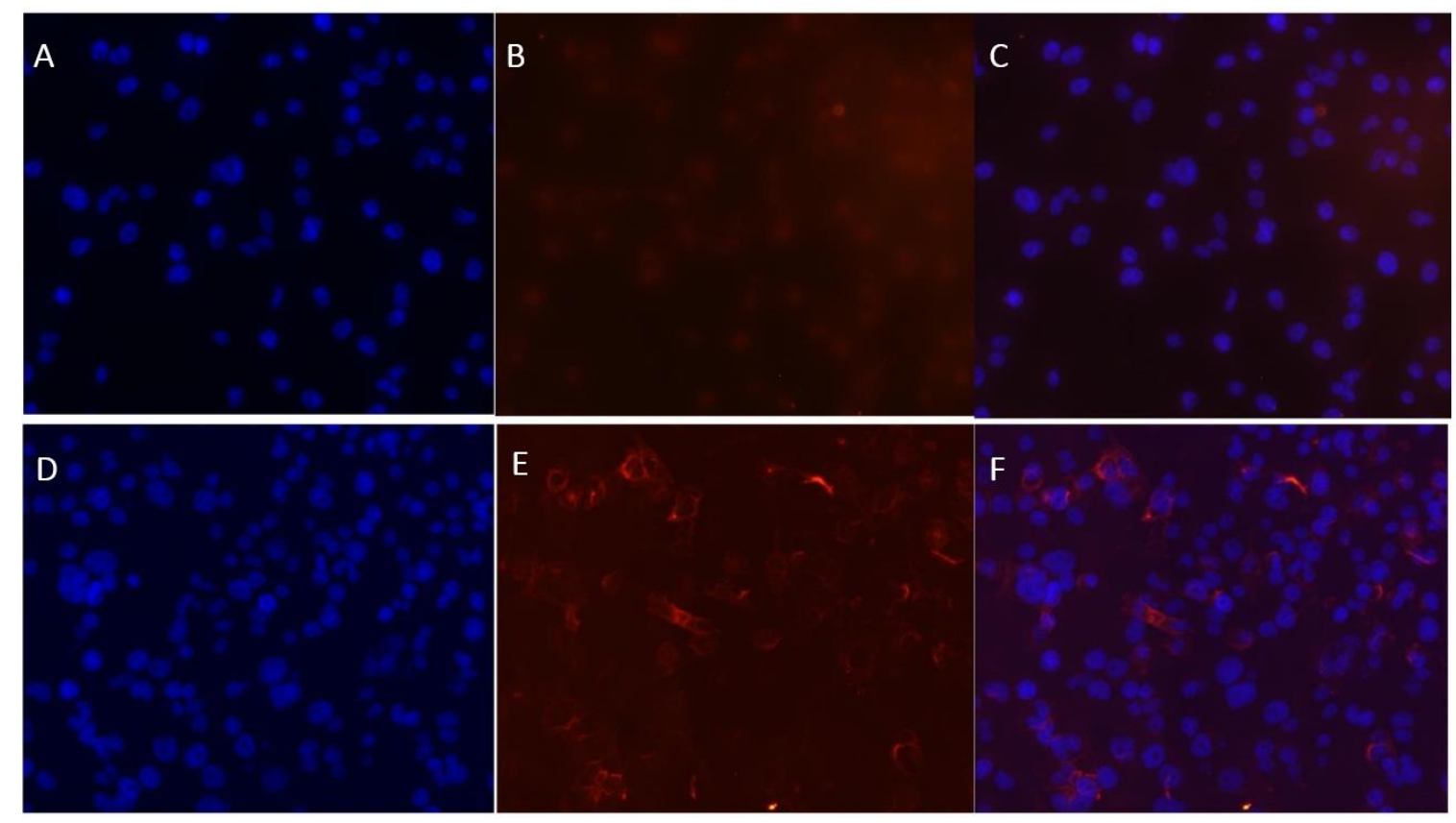

A parte superior $(A, B$ e $C$ ) representa o controle $\mathrm{CHO}$ que não recebeu o anticorpo primário, e a parte inferior (D, E e F) representa a amostra de CHO com anticorpo anti-ICAM1. As letras A e D mostram a marcação dos núcleos com DAPI, em azul; B e E mostram a marcação com AlexaFluor 594, em vermelho; e C e F mostram a sobreposição de ambos fluoróforos.

Para verificar se a ausência de detecção de CD36 estava relacionada à concentração do anticorpo anti-CD36, repetimos o ensaio com diferentes concentrações do mesmo: 1:200, 1:100 e 1:20, com duas alíquotas de CHO-CD36 (uma mais antiga e outra mais recente). 
A Figura 26 mostra os resultados do ensaio com a alíquota de células mais antiga, uma vez que não conseguimos detectar fluorescência na alíquota mais recente, a qual que permaneceu em cultivo por mais tempo e pode ter perdido a expressão do gene.

Poucas células foram encontradas na concentração 1:200. Porém, observamos que com o aumento na concentração do anticorpo anti-CD36 tornava-se mais fácil visualizar células com fluorescência vermelha (AlexaFluor 594), revelando assim, a presença do receptor CD36.

Figura 26 - Imunofluorescência das células CHO-CD36 com maior concentração de anticorpo.
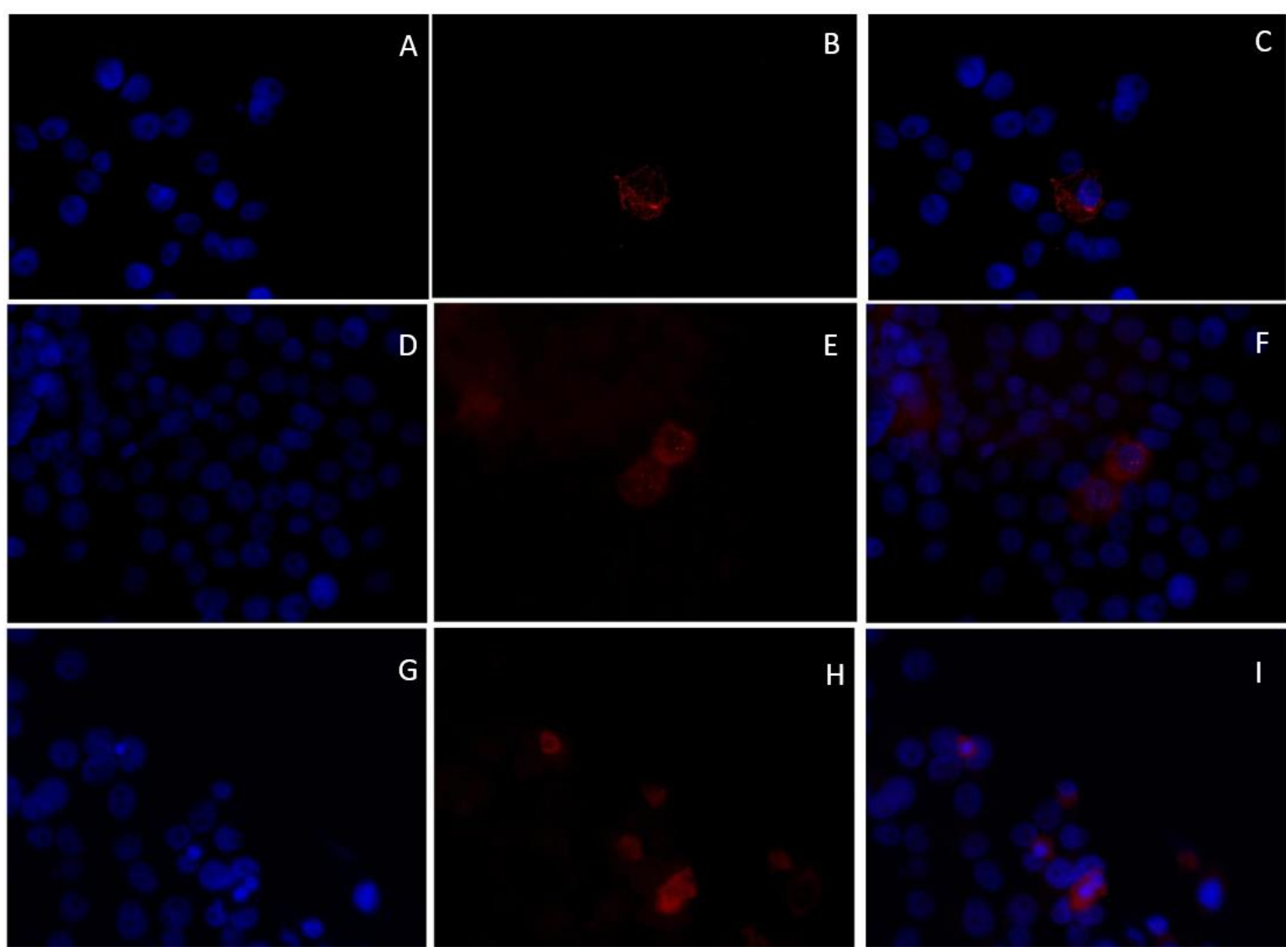

Ensaio de imunofluorescência das células CHO-CD36 com anticorpo primário diluído 1:200 em A, B e C; diluído 1:100 em D, E e F e 1:20 em G, H e I. A letra A mostra a marcação das células com DAPI, B mostra a marcação com AlexaFluor 594, C mostra a sobreposição de ambos fluoróforos. 
Diante destes resultados, acreditamos que nos últimos procedimentos de panning realizados com alguns isolados de campo, as células CD36 poderiam ter sofrido uma drástica redução na expressão do seu receptor de membrana, e como consequência, ao invés de selecionar o fenótipo adesivo a CD36, o parasita manteve seu grau de adesão ou até sofreu uma ligeira perda, devido ao tempo transcorrido em cultura. Infelizmente, foi uma falha que detectamos tardiamente, mas podemos assegurar que nos experimentos iniciais, estas células estavam apropriadas, assim como as CHO-ICAM1, e que nos ensaios de posteriores, o problema havia sido sanado.

\subsection{Análise de reconhecimento de anticorpos por Citometria de Fluxo}

Nós analisamos se a intensidade de resposta de anticorpos provenientes de 306 amostras de soros de moradores do Ramal do Granada (seção 3.1) contra oito VSAs. A tabela 13 mostra a quantidade de soros que reconheceram cada um dos VSAs.

Tabela 13 - Porcentagem de amostras de soro que reconhecem cada isolado testado.

\begin{tabular}{|lcccccccc|}
\hline & 38A & 38A CD36 & 38AICAM & FMS & FMS CD36 & Pf03 & 94A & 3D7 \\
\hline \hline $\begin{array}{l}\text { Número de soros } \\
\text { que reconheceram }\end{array}$ & 56 & 14 & 85 & 31 & 74 & 2 & 29 & 32 \\
$\begin{array}{l}\text { Porcentagem de } \\
\text { reconhecimento }\end{array}$ & 19,4 & 4,6 & 27,4 & 10,1 & 24,6 & 0,7 & 9,5 & 10,5 \\
\hline
\end{tabular}

A Figura 27 mostrou que a análise de correlação entre as variáveis: tempo de Amazônia e número de antígenos reconhecidos foi significativa, ou seja, quanto maior o tempo de exposição de um indivíduo em uma área de risco de infeç̧ão, maior a chance dele produzir anticorpos que reconheçam diferentes antígenos . 
Figura 27 - Análise de correlação entre tempo de moradia na Amazônia e o número de isolados reconhecidos por cada amostra de soro.

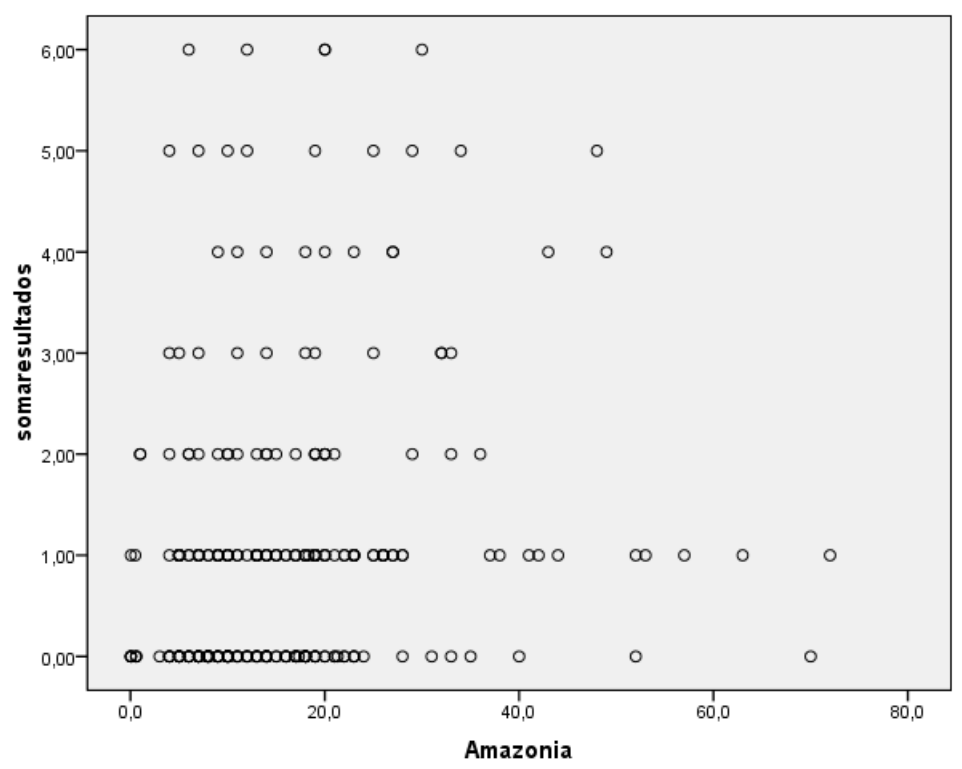

O gráfico correlaciona o tempo exposição dos 306 indivíduos na Região Amazônica (os valores do eixo das abcissas estão expressos em anos), e o número que variantes que eles reconheceram (Somaresultados no eixo das ordenadas), sendo "zero", nenhum reconhecimento e "seis" o máximo de variantes reconhecidas ao mesmo tempo por alguns soros.

Análise de correlação mostrou-se significativa para as variáveis tempo de Amazônia e número de antígenos reconhecidos, ou seja, quanto maior o tempo de exposição em uma área de risco de infecção, maior a chance de um indivíduo produzir anticorpos que reconheçam diferentes antígenos (Spearman's rank test, $\rho=0,243 ; p<$ $0,01)$.

Não observamos correlação entre reconhecimento por anticorpos e idade. O tempo de moradia em Acrelândia teve correlação apenas com o reconhecimento do isolado 94A, entretanto, o tempo de moradia na Amazônia teve correlação significativas para todos os isolados, exceto 3D7 e Pf03. 
Tabela 14 - Tabela de correlação entre idade, tempo de moradia na área de estudo e tempo de moradia na Amazônia com a intensidade de reconhecimento de cada isolado testado.

\begin{tabular}{|c|c|c|c|c|c|}
\hline & & & Idade & Acrelândia & Amazônia \\
\hline \multirow[t]{16}{*}{ Spearman's rho } & \multirow[t]{2}{*}{$38 \mathrm{~A}$} & Coeficiente de Correlação &, 071 &, 106 &, $237^{\star \star}$ \\
\hline & & Significância & 229 & 074 &, 000 \\
\hline & \multirow[t]{2}{*}{$38 A^{C D 36}$} & Coeficiente de Correlação & ,062 &,- 048 &, $233^{\star *}$ \\
\hline & & Significância & 281 & 405 &, 000 \\
\hline & \multirow[t]{2}{*}{$38 A^{\text {ICAM }}$} & Coeficiente de Correlação & 011 &,- 073 & $156^{\star *}$ \\
\hline & & Significância & ,853 & 202 &, 006 \\
\hline & \multirow[t]{2}{*}{$94 \mathrm{~A}$} & Coeficiente de Correlação & ,043 &, $218^{\star *}$ &, $175^{* *}$ \\
\hline & & Significância & ,455 &, 000 &, 002 \\
\hline & \multirow[t]{2}{*}{ FMS } & Coeficiente de Correlação & ,053 &, 044 &, $130^{*}$ \\
\hline & & Significância & ,357 & ,447 & ,023 \\
\hline & \multirow[t]{2}{*}{$\mathrm{FMS}^{\mathrm{CD} 36}$} & Coeficiente de Correlação & ,024 & ,090 & $146^{*}$ \\
\hline & & Significância & ,679 &, 117 &, 011 \\
\hline & \multirow[t]{2}{*}{ Pf03 } & Coeficiente de Correlação & ,028 & ,067 & ,084 \\
\hline & & Significância & ,627 & 242 & 142 \\
\hline & \multirow[t]{2}{*}{$3 \mathrm{D} 7$} & Coeficiente de Correlação & ,094 &,- 091 & ,064 \\
\hline & & Significância & 100 & 114 & 265 \\
\hline
\end{tabular}

Dos 284 indivíduos que possuíamos informação sobre infecção no período da coleta, 259 foram negativos por PCR e microscopia e 25 indivíduos foram positivos para os dois métodos. Dentre os positivos, 16 eram assintomáticos e nove possuíam sintomas. Porém, não constatamos associação entre a presença de infecção e/ou sintomas com os níveis de reconhecimento por anticorpos a nenhum dos isolados ( $p>0,185$ e $p<0,977)$.

Também não averiguamos associação entre os níveis de resposta e o sexo dos indivíduos $(p>0,256$ e $p<0,942)$.

\subsection{Ensaios de bloqueio de adesão em células $\mathrm{CHO}$}

Nos ensaios de bloqueio de adesão, nós queríamos saber se um soro que reconhece bem a PfEMP1 de um isolado ${ }^{C D 36}$, por exemplo, seria capaz de bloquear não só a aderência desse mesmo isolado, mas também de um outro isolado ${ }^{\mathrm{CD} 36}$ cujo soro pouco reconheceu (ver seção 3.13). Desta forma, selecionamos os soros: 426 como o que mais reconheceu o antígeno de $38 \mathrm{~A}^{\mathrm{CD} 36}$ e pouco reconheceu $\mathrm{FMS}^{\mathrm{CD} 36}$; o soro 517 para o isolado $\mathrm{FMS}^{\mathrm{CD} 36}$; o soro 477 para o isolado Pf03 e o soro 426 para $38 \mathrm{~A}^{\text {ICAM }}$. 
Para facilitar a associação soro/isolado, os gráficos a seguir possuem o título com o nome do isolado da mesma cor do soro que melhor o reconhece, indicado na legenda.

Figura 28 - Análise de bloqueio de adesão em CHO-ICAM-1.
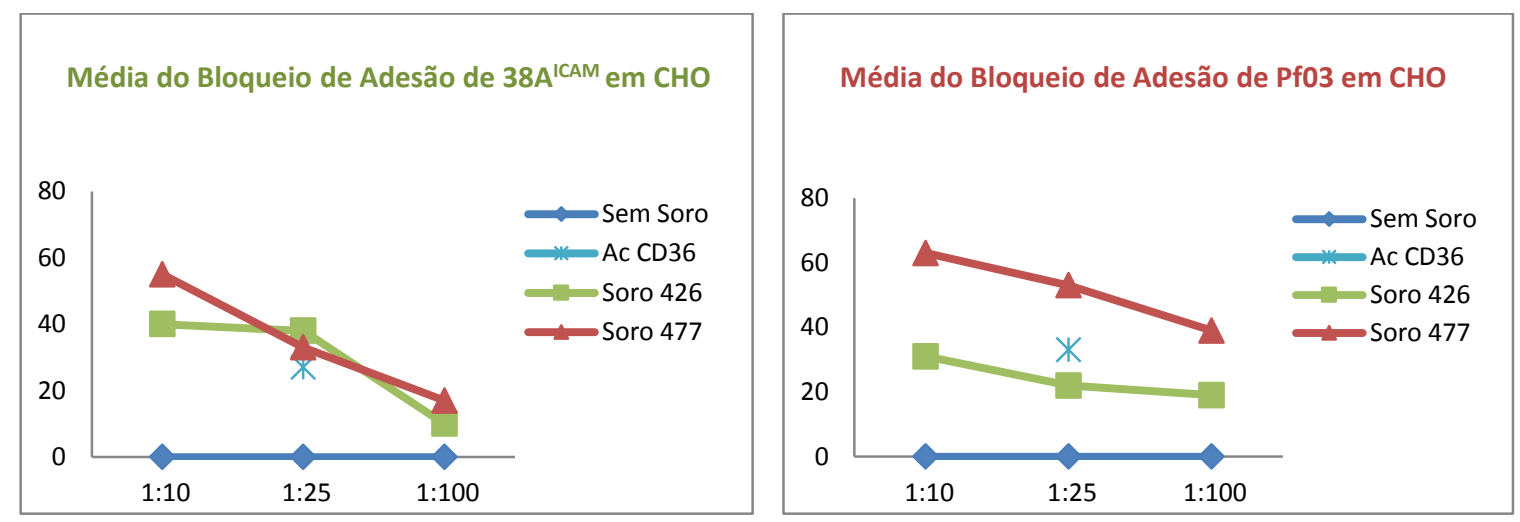

Os gráficos que representam a média dos ensaios de bloqueio de adesão dos isolados $38 \mathrm{~A}^{\text {ICAM }}$ (esquerda) e Pf03 (direita) a células CHO-ICAM1. O eixo das abcissas indica a diluição do soro e o eixo das ordenadas indica a porcentagem de bloqueio obtida, considerando como "zero" a capacidade de adesão sem adição de soro. $O$ controle com anticorpo específico foi sempre utilizado na concentração 1:25.

O soro 477 inibiu mais a adesão de PfO3 que o soro 426 às células CHO-ICAM1, mas ambos os soros tivem capacidade de bloqueio semelhante em relação à adesão de $38 A^{\text {ICAM }}$.

Figura 29 - Análise de bloqueio de adesão a células CHO-CD36.

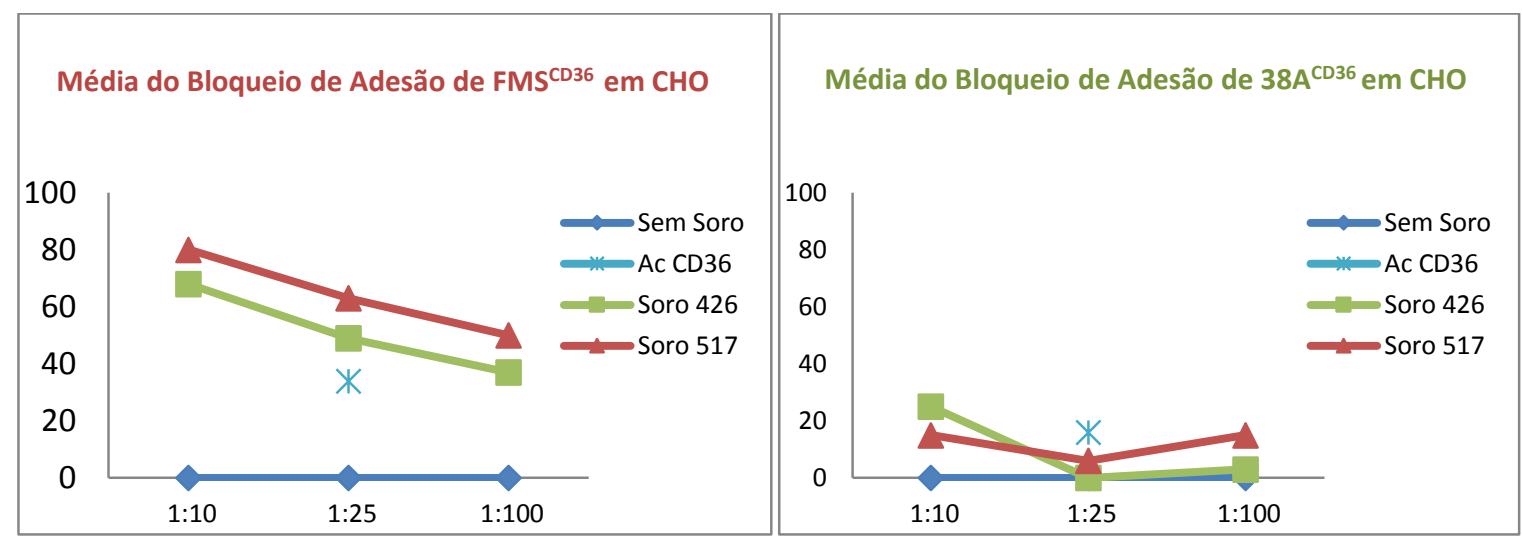

Os gráficos que representam a média dos ensaios de bloqueio de adesão dos isolados FMS ${ }^{\mathrm{CD} 36}$ (à esquerda) e $38 \mathrm{~A}^{\mathrm{CD} 36}$ (à direita) a células $\mathrm{CHO}-\mathrm{CD} 36$. Os gráficos da parte inferior da figura mostram os resultados das duas réplicas experimentaris. $O$ eixo das abcissas indica a diluição do soro e o eixo das ordenadas indica a porcentagem de bloqueio obtida, considerando como "zero" a capacidade de adesão sem adição de soro. 0 controle com anticorpo específico foi sempre utilizado na concentração 1:25. 
Observamos que o soro 517 inibiu sutilmente mais a adesão de FMS CD36 que o soro 426 , entretanto, o soro 426 foi mais eficaz no bloqueio de $\mathrm{FMS}^{\mathrm{CD} 36}$ do que de $38 \mathrm{~A}^{\mathrm{CD} 36}$. Ambos os soros tiveram capacidade reduzida em bloquear a adesão de $38 \mathrm{~A}^{\mathrm{CD} 36}$.

\subsection{Ensaios de Bloqueio de Adesão em CD36 recombinante}

A capacidade de bloqueio dos soros sobre uma superfície de receptores purificados foi bem mais eficiente que nas células $\mathrm{CHO}$, onde existem outras interações célula-EP.

Figura 30 - Análise de bloqueio de adesão em CD36 recombinante (rCD36).

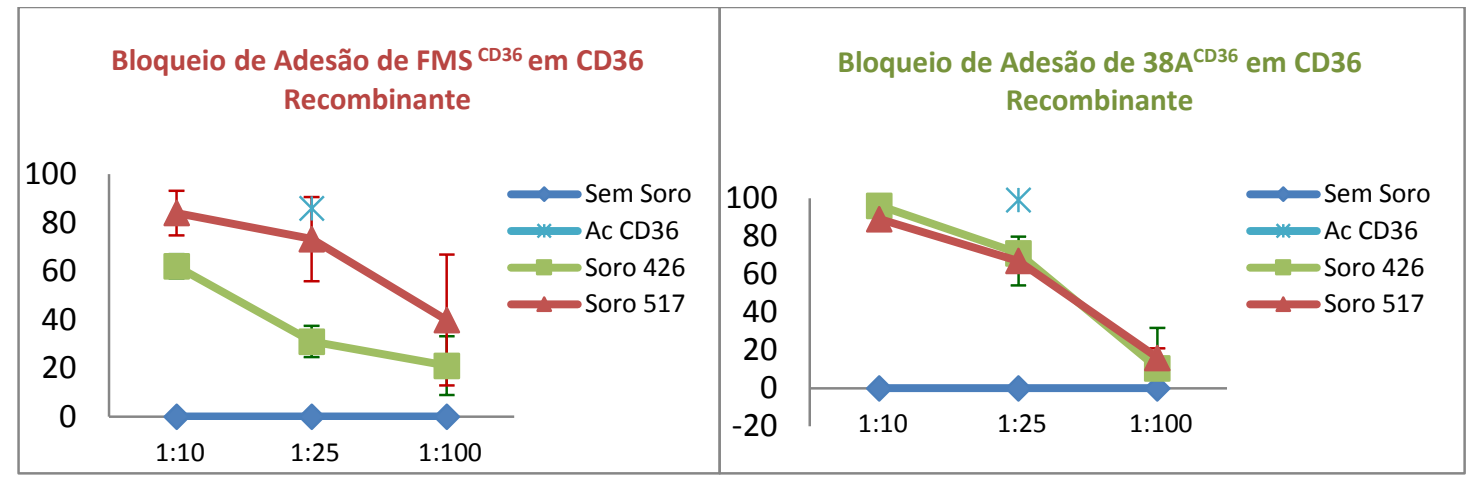

Os gráficos com as médias dos ensaios de bloqueio de adesão dos isolados FMS ${ }^{\operatorname{CD} 36}$ (à esquerda) e $38 \mathrm{~A}^{\operatorname{CD} 36}$ (à direita) aoreceptor rCD36. O eixo das abcissas indica a diluição do soro e o eixo das ordenadas indica a porcentagem de bloqueio obtida, considerando como "zero" a capacidade de adesão sem adição de soro. 0 controle com anticorpo específico foi sempre utilizado na concentração 1:25. As barras de erro indicam o erro padrão.

Ao mesmo tempo em que o soro 517 inibe mais a adesão de $\mathrm{FMS}^{\mathrm{CD} 36}$ ao receptor rCD36 do que o soro 426, ambos os soros apresentaram a mesma capacidade de inibição de adesão do isolado $38 \mathrm{~A}^{\mathrm{CD} 36}$. Apesar da porcentagem de bloqueio ter sido superior nas rCD36 quando comparado com as $\mathrm{CHO}$, o efeito dos soros foi bem semelhante, mostrando que apesar de um soro ter reconhecido pouco o outro (Figura 7), existe uma plasticidade na capacidade de impedir a adesão. 


\subsection{Ensaios de Bloqueio de Adesão em ICAM-1 recombinante}

Nós fizemos tentativas de adesão a rICAM-1 usando diferentes concentrações da proteína, mas em nenhuma delas os EP foram capazes de permanecerem aderidos durante o experimento. Para verificar se não era um problema de coating dos receptores à placa, nós realizamos um teste de Elisa para confirmar a presença da proteína, como mostra a Tabela 15.

Tabela 15 - Resultados do ELISA para ICAM-1.

\begin{tabular}{|ccccccc|}
\hline Nome & Poço & Leitura 2:450 & Contagem & Média & $\begin{array}{c}\text { Desvio } \\
\text { Padrão }\end{array}$ & CV (\%) \\
\hline \hline vazio & A1 & 0,045 & 2 & 0,044 & 0,001 & 3,34 \\
BSA & A2 & 0,043 & & & & \\
BSA & A3 & 0,047 & 2 & 0,911 & 1,222 & 134 \\
ICAM (C/B) 10ug & A4 & 1,775 & & & & \\
ICAM (C/B) 20ug & A5 & 1,734 & 2 & 1,697 & 0,053 & 3,1 \\
ICAM (PBS) 10ug & A6 & 1,660 & & & & \\
ICAM (PBS) 20ug & A7 & 1,671 & 2 & 0,875 & 1,126 & 129 \\
Branco & A8 & 0,079 & & & & \\
\hline
\end{tabular}

Foram testados 10 e $20 \mu \mathrm{g} / \mathrm{ml}$ da proteína em tampão Carbonato Bicarbonato (C/B) e em PBS [1x]. Fizemos um controle somente com o anticorpo secundário (Branco) e dois controles sem proteína, um com BSA 2\% e outro sem nada na superfície da placa (vazio).

Testamos duas concentrações da proteína em dois tampões diferentes, e todos foram positivos para a presença da proteína, concluindo que os isolados não foram capazes de aderir ao receptor isoladamente.

\subsection{Genotipagem da hemoglobina}

A tipagem do gene que codifica a cadeia beta da hemoglobina, e que permite, portanto, distinguir entre $\mathrm{HbA}$ (normal) e HbS (mutado) é o SNP rs334. Somente os indivíduos homozigotos para esse alelo, ou seja, tendo o genótipo rs334 (TT), terá anemia falciforme. 
Foram tipados 406 indivíduos, residentes no Ramal do Granada (descritos na seção 3.1), entre os quais 398 (98\%) apresentaram alelos normais rs334(AA) e oito indivíduos (2\%) mostraram-se heterozigotos para o alelo da anemia falciforme, rs334 (AT), descritos na tabela 8. Nenhum dos indivíduos apresentou-se homozigoto para o alelo mutado.

Tabela 16 - Indivíduos heterozigotos para hemoglobina S

\begin{tabular}{cccccc}
\hline Indivíduo & Profissão & Sexo & Idade & $\begin{array}{c}\text { Tempo de } \\
\text { Acrelândia }\end{array}$ & $\begin{array}{c}\text { Tempo de } \\
\text { Amazônia }\end{array}$ \\
92 & Agente de saúde & Masculino & 52 & 10 & 52 \\
215 & Agricultor & Masculino & 53 & 15 & 15 \\
216 & Agricultora & Feminino & 17 & 14 & 14 \\
217 & Agricultora & Feminino & 20 & 14 & 14 \\
220 & Estudante & Masculino & 11 & 11 & 11 \\
424 & Dona de casa & Feminino & 24 & 4 & 4 \\
453 & Estudante & Feminino & 9 & 5 & - \\
621 & - & Feminino & - & - & 9 \\
\hline
\end{tabular}

Dados adquiridos no momento da coleta, em 2004.

\subsection{Análise do potencial de adesão do isolado $38 A^{\text {ICAM }}$ cultivado em meio suplementado com Albumax e meio suplementado com plasma}

Segundo et al. (2007) o cultivo em meio Albumax pode prejudicar a exportação de PfEMP1 para a superfície da hemácia parasitada. Como nossos isolados foram cultivados em Albumax, realizamos um novo ensaio de adesão em CHO-ICAM1, utilizando o isolado $38 \mathrm{~A}^{\text {ICAM }}$, cultivando-o por cinco dias em meio suplementado com 0,05\% de Albumax e em meio suplementado com $10 \%$ de plasma, utilizando a mesma metodologia descrita na 
seção 3.8.1, porém, ao invés de $5 \times 10^{4} \mathrm{EP}$, utilizamos apenas $1 \times 10^{4}$ devido ao escasso período de tempo disponível para realização da contagem da lâmina.

Como podemos observar na Figura 37, tivemos uma redução de aproximadamente $50 \%$ na capacidade de adesão quando o parasita é mantido em meio suplementado com Albumax, tornando necessário considerar este efeito na discussão dos dados.

Figura 31 - Citoaderência de $38 \mathrm{~A}^{\text {ICAM }}$ cultivado em meio com Albumax e em meio com plasma a células CHO-ICAM1.

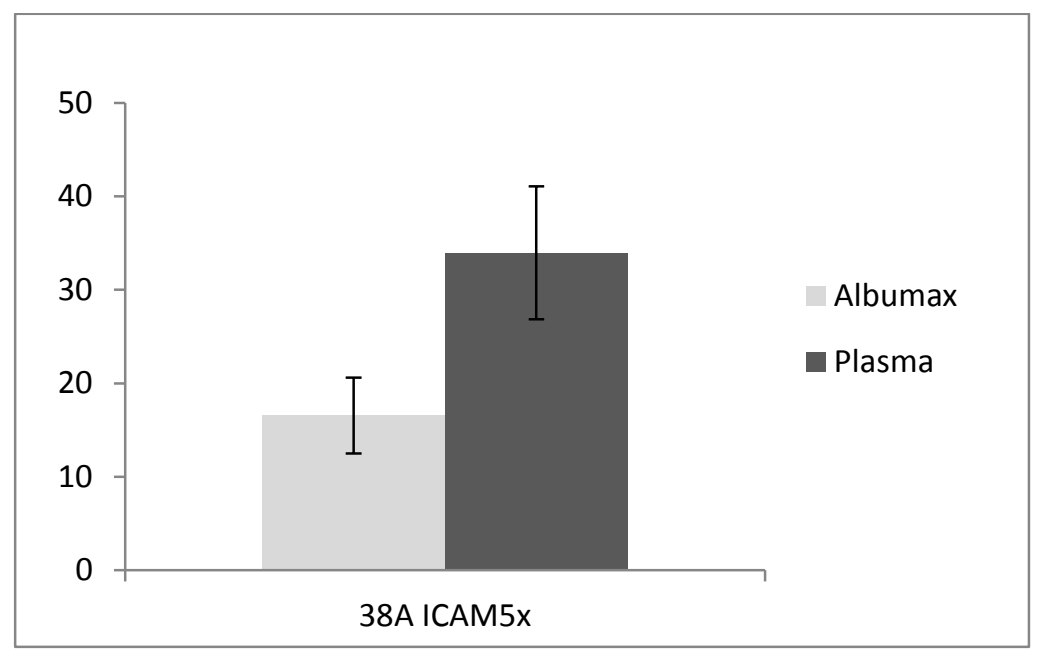

Gráfico cujo eixo das ordenadas está expresso em EP/ $/ \mathrm{mm}^{2}$ aderidos a uma superfície de células CHO-ICAM1 para o isolado $38 \mathrm{~A}^{\mathrm{ICAM}}$ cultivado em meio Albumax (barra em cinza claro) e cultivado em meio com plasma (carra em cinza escuro). As barras de erros representam o desvio padrão. 
5 DISCUSSÃO 


\subsection{Aderência de isolados de $P$. falciparum da Amazônia brasileira a CD36 e ICAM-1}

Este trabalho teve início com a caracterização de sete isolados de campo de provenientes dos Estados do Acre e Amazonas, quanto ao perfil de citoaderência. De modo geral, a maioria dos isolados apresentou características biaderentes, permanecendo assim, ou apresentando leves alterações após os procedimentos de

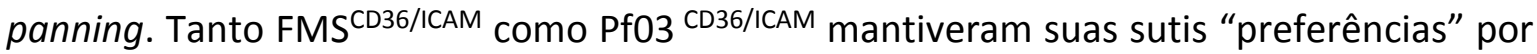
CD36 e ICAM-1, respectivamente, mesmo após a seleção por panning (Figura 11). A princípio, julgamos que essas variações poderiam ser decorrentes da existência de múltiplos clones em uma mesma amostra, de modo que esses fenótipos inesperados seriam consequência da competição entre as variantes pela adesão aos receptores (Phiri et al., 2009). Para solucionar essa questão, nós realizamos uma análise de microssatélites, onde não constatamos a presença de mais de um clone por amostra de isolado, já no primeiro ensaio de diagnóstico de citoaderência (seção 4.8).

Estudos com isolados de campo mostraram que todos os parasitas, provenientes de indivíduos com malária grave ou não, foram capazes de aderir a CD36, e que a maioria também aderiu a ICAM-1 (Heddini et al., 2001; Newbold et al., 1997). Porém, não está claro se a capacidade de aderir a mais de um receptor se deve à expressão de um gene var que codifica uma PfEMP1 "poliaderente" ou se é devido à co-expressão de genes var (Joergensen et al., 2010).

Também analisamos a presença do gene kahrp, e observamos que o 94A foi o único isolado com deleção desse gene, o que acarretou na ausência da formação de knobs na superfície das hemácias parasitadas, e consequentemente, resultou em um fenótipo não adesivo, como pudemos observar em nossos ensaios (Figuras 8 e 9).

$\mathrm{FMS}^{\mathrm{CD} 36}$ e FMS ${ }^{\text {ICAM }}$ tiveram uma maior capacidade de permanecerem aderidos com a passagem de fluxo, e assim como $38 \mathrm{~A}^{\mathrm{CD} 36}$, foram capazes de aderir em condições de fluxo. Cabe ressaltar que as células HLEC, utilizadas nesses ensaios, foram doadas pela equipe do Dr. Fabio T. Costa e caracterizadas por eles através de citômetro de fluxo (FACScanto/Becton \& Dickson), apresentando predomínio de expressão de ICAM-1 (dados não publicados).

Houve uma grande diferença entre $38 \mathrm{~A}^{\mathrm{CD} 36}$ e $38 \mathrm{~A}^{\text {ICAM }}$, tanto na capacidade de aderir como na capacidade de permanecer aderido sob as condições de fluxo, de modo 
que a interação com ICAM-1 não pôde ser sustentada (Figura 18), considerando que $38 \mathrm{~A}^{\text {ICAM }}$ possui a PfEMP1 melhor selecionada para ICAM1 (Figura 11).

Gray et al. (2003) propuseram que ICAM-1 seria responsável por capturar eritrócitos parasitados (EP) do fluxo sanguíneo, mediando o rolling de adesão e facilitando a ligação a CD36. Li et al. (2011) mostraram que a ligação de CD36 a EP é mais estável que entre EP e TSP (trombospodina), embora a interação entre EP/TSP seja mais forte do que a interação com CD36, sugerindo que TSP possa iniciar a adesão dos EP enquanto CD36 mantém a estabilidade da ligação.

Comparando esses dados com os resultados dos ensaios em fluxo, nós vimos que a interação entre $38 \mathrm{~A}^{\mathrm{CD} 36}$ às células HLEC tiveram uma maior estabilidade de adesão do que $38 A^{\text {ICAM }}$. Já FMS, cujos fenótipos se mantiveram "biaderentes", constatamos que uma vez aderidos, pouco se desprendem com a passagem do fluxo, sugerindo que a PfEMP1 de FMS possa ter interagido mais facilmente com o ICAM-1 e o CD36 presentes na HLEC, de modo que a interação com ICAM-1 possa ter sido estabilizada, ou favorecida por outras interações com CD36 em um quadro de sinergia, como descrito por McCormick et al. (1997). Estes autores descreveram um quadro de sinergia entre CD36 e ICAM-1 expressos em HDMEC (human dermal microvascular endothelial cells), em que a capacidade de adesão do isolado era maior quando os dois receptores eram expressos concomitantemente.

Adicionalmente, pudemos observar a importância da existência de interações adjacentes responsáveis pela adesão dos EP à ICAM-1 quando constatamos que o isolado $38 \mathrm{~A}^{\text {ICAM }}$ era incapaz de aderir ao receptor ICAM-1 isoladamente (também testamos com os isolados 38A e Pf03 não selecionados) (seção 4.15). A interação EP/ICAM-1 parece exigir a presença de outros ligantes que lhes dê sustentação, o que não ocorreu com CD36 recombinante (seção 4.14).

Seria muito interessante poder realizar as mesmas análises utilizando em paralelo, isolados provenientes de regiões endêmicas da África e Ásia, para aí sim, podermos afirmar que os resultados que encontramos aqui são características específicas dos isolados brasileiros, e portanto de menor virulência, se tomarmos como parâmetro de virulência a capacidade de adesão à receptores do endotélio vascular, e particularmente a ICAM-1 no caso de malária cerebral. 
Alguns fatores podem ter influenciado na capacidade de aderência e na dificuldade que tivemos em selecionar parasitas monofenotípicos. Em primeiro lugar, através caracterização inicial do perfil de adesão dos sete isolados, nós pudemos observar que a adesão a ICAM-1 pareceu ser reduzida (Figura 10C e 10E) ou mesmo perdida (Figura $10 \mathrm{D}$ e 10F) com o passar do tempo, uma vez que os isolados que aderiram mais a ICAM-1 tiveram sua capacidade diminuída com o decorrer de alguns ciclos. De acordo com o trabalho de Zhang et al. (2011), onde foram comparadas as características de isolados ex vivo e após dois meses de cultura in vitro, eles observaram que a aderência a CD36 foi característica de todos os isolados cultivados exceto um, e essa propriedade foi mantida durante todo o período de cultura. $\mathrm{O}$ isolado que inicialmente aderia a ICAM-1 logo mudou seu perfil e passou a aderir a CD36. A aderência a ICAM-1 nos demais isolados foi pontual (30 e 45 dias cultura), seguido da perda dessa habilidade.

Em segundo lugar, constatamos variação de expressão de CD36 e ICAM-1 nas células $\mathrm{CHO}$ transfectadas. Outros autores que utilizaram estas células para o mesmo fim não relataram nenhum detalhe sobre a expressão ou não de receptores nas linhagens, aparentemente assumindo que não houve mudança de expressão. Apesar de termos detectado a presença dos receptores nas células, a expressão dos receptores não foi tão alta e algumas alíquotas de $\mathrm{CHO}-\mathrm{CD} 36$ não mostraram a presença da proteína. Concluímos, portanto, que uma avaliação frequente na presença desses receptores deve ser estabelecida como rotina para os estudos que utilizam essas células.

E por último, mas não menos importante, se refere ao cultivo dos parasitas em meio suplementado com Albumax ao invés de plasma/soro. Frankland et al. (2007) relataram a importância do colesterol, contido no plasma, para o transporte da PfEMP1 rumo à superfície da hemácia, de modo que quando o parasita é cultivado em meio com Albumax, ocorre uma redução na exportação de proteínas para a superfície. Para sanarmos essa dúvida, nós realizamos um último ensaio de citoaderência em CHO-ICAM1 com o isolado $38 \mathrm{~A}^{\mathrm{ICAM}}$, cultivando-o em Albumax e em plasma por cinco dias. Uma vez que a expressão do gene que codifica a PfEMP1 não cessa, o parasita volta a exportar suas proteínas no ciclo seguinte (Frankland et al., 2007). Os resultados mostraram uma média de duas vezes mais aderência no cultivo com plasma (Figura 37). Apesar de haver sim exportação de PfEMP1 com Albumax, muito provavelmente nós não estávamos obtendo o melhor "desempenho" dos nossos parasitas, o que pode ter prejudicado os 
processos de seleção por panning, e que talvez explique parcialmente a variação da capacidade de aderência de um mesmo isolado.

Entretanto, como todos os isolados foram tratados da mesma maneira com Albumax, nossos resultados permanecem comparáveis entre si, e apesar dos problemas relatados, a seleção fenotípica do isolado 38A mostrou-se eficiente (Figura 11) e os resultados de adesão e em CHO e HLEC mostraram-se compatíveis.

Adicionalmente, a literatura também relata alterações no padrão de adesão de isolados de campo (Gray et al., 2003; Zhang et al., 2011). Experimentos em fluxo com isolados, provenientes de pacientes que foram a óbito devido à malária cerebral, que aderiam bem a ICAM-1 estaticamente, não se mostraram eficientes em aderir a ICAM-1 em fluxo, e o inverso também foi observado, o isolado que se ligava menos a ICAM-1 estaticamente, obteve uma adesão em fluxo mais eficiente (Gray et al. 2003).

Embora tenhamos tentado simular uma situação mais próxima das condições fisiológicas, através dos ensaios de citoaderência em fluxo com células endoteliais humanas (HLEC), seria interessante realizar esses experimentos com as células HBEC (human brain endotheial cells), que recentemente estão sendo cultivadas com êxito e utilizadas nos estudos de malária cerebral (Khaw et al., 2013).

\subsection{Reconhecimento de anticorpos de indivíduos naturalmente expostos à malária na Amazônia brasileira a VSAs locais capazes de mediar aderência a CD36 e ICAM-1}

Uma vez selecionados os isolados, queríamos então saber se os diferentes antígenos apresentados nas hemácias parasitadas poderiam ser reconhecidos pelos 306 soros de indivíduos residentes do Ramal do Granada (seção 3.1), escolhidos aleatoriamente dentre as 500 amostras coletadas em 2004.

As análises de citometria de fluxo mostraram uma porcentagem de reconhecimento (ou seja, proporção de indivíduos soropositivos) que variou de 0,7 a $27,4 \%$, dependendo do antígeno (Tabela 13), sendo o $38 \mathrm{~A}^{\text {ICAM }}$ o isolado mais reconhecido e o Pf03, o menos reconhecido, de modo que os parasitas com perfil de adesão parecido não foram necessariamente reconhecidos pelos mesmos indivíduos. 
A intensidade de resposta não teve associação com o sexo dos indivíduos e nem com a presença de infecção, tanto sintomática quanto assintomática. Este último resultado pode ter sido encontrado devido ao pequeno número de indivíduos infectados (25 em 284).

O tempo de exposição em Acrelândia, assim como o tempo de exposição na Amazônia correlacionaram-se com o reconhecimento do isolado $94 \mathrm{~A}$, mostrando que apesar de se tratar de um parasita knob-negativo, ele é capaz de expor de VSAs na superfície da hemácia parasitada.

Estudos mostraram que a ausência de KAHRP na membrana do eritrócito leva a um enfraquecimento da interação entre PfEMP1 e o endotélio vascular, afetando a rigidez da membrana e a citoaderência sob condições fisiológicas de fluxo, mas que isolados knobless são capazes de apresentar PfEMP1 na superfície dos eritrócitos, porém, a interação com receptores é muito menos estável quando comparada com isolados knob positivos (Crabb et al., 1997, Rug et al., 2006). Na mesma direção, Horrocks et al. (2005) realizaram uma detecção de PfEMP1 tipo 41 em isolados knob positivos e negativos, e observaram um padrão muito semelhante de reconhecimento por anticorpos na superfície do eritrócito, evidenciando que a molécula foi capaz de ser incorporada na membrana plasmática do eritrócito.

As análises de correlação mostraram-se significativas entre o tempo de moradia na Amazônia (que reflete o tempo de exposição à malária) e o reconhecimento dos diferentes isolados, exceto para 3D7 e Pf03, ou seja, o período de exposição aos diferentes antígenos circulantes em áreas endêmicas favoreceu o reconhecimento por anticorpos.

Um grande número de estudos sugere que a aquisição de imunidade esteja relacionada ao tempo de exposição do indivíduo ao parasita. Na região Amazônica, temos visto que a prevalência das infecções e a proporção de infecções sintomáticas é reduzida com o tempo de exposição (Ladeia-Andrade et al., 2009). Em um cenário de transmissão hipo/mesoendêmico, nativos da Amazônia adquirem imunidade com poucos anos de exposição, não sendo raro encontrar indivíduos adultos infectados, porém sem manifestações clínicas (Alves et al. 2002; Alves et al., 2005).

Um estudo realizado no Mali mostrou que crianças foram capazes de reconhecer parasitas genética e geograficamente distintos, e que a resposta de IgG era maior em 
época de transmissão da doença. Os autores supõem que ou as crianças produzem anticorpos que reconheçam vários parasitas, ou produzem IgGs linhagem-específica, ou mesmo, que ambas respostas ocorram conjuntamente (Zeituni et al., 2013).

Em regiões hiperendêmicas da África, o risco das crianças desenvolverem formas graves da doença é bastante reduzido após poucos episódios de infecção por $P$. falciparum (Gupta et al., 1999; Marsh, Snow 1997; Nielsen et al., 2002), condizendo com estudos que demonstraram que PfEMP1 relacionadas à malária grave, codificadas por genes var do grupo A, são mais conservadas que os demais grupos de genes var, explicando portanto, a rápida aquisição de imunidade contra malária grave após alguns episódios (Jensen et al., 2004, Turner et al., 2013). No entanto, Doolan et al. (2009) constataram a importância da maturação natural do sistema imune através de um estudo com migrantes adultos em região endêmica. Durante o primeiro ano no local, uma prevalência de infecções foi idêntica a das crianças, porém, passados 18-24 meses, os adultos apresentaram diminuição importante na prevalência das infecções, enquanto as crianças permaneceram com a mesma taxa de infecção.

Recentes trabalhos têm associado a malária grave com a expressão de subtipos de PfEMP1 contendo domain cassettes DC8 e DC13 (Avril et al., 2012; Claessens et al., 2012, Turner et al., 2013) cujo receptor, identificado recentemente, é o EPCR (receptor de proteína C endotelial) que medeia o efeito citoprotetor da proteína C ativada, uma proteína também envolvida na via de coagulação do sangue, inflamação, morte celular, manutenção da permeabilidade da parede dos vasos. Testes realizados por Turner et al. (2013) demonstraram que DC8 e DC13 impedem a ligação de APC (proteína C ativada) ao EPCR, indicando uma competição pelo mesmo sítio de ligação, e portanto, a adesão do parasita mediada por EPCR poderia interferir na ativação das vias citoprotetoras e antiinflamatórias, que por sua vez, contribuiriam para a patologia da malária grave. No entanto, Bengtsson et al. (2013) não descartam a importância de ICAM-1 como receptor de DC4, que também vem sendo associado à malária grave. Desta forma, seria muito interessante analisar a reação de anticorpos contra PfEMP1-DC8, DC13 e DC4. 


\subsection{Capacidade dos anticorpos de indivíduos naturalmente expostos à malária na Amazônia brasileira de bloquearem a aderência de isolados locais a CD36 e ICAM-1}

Uma vez que existe reconhecimento por anticorpos e que alguns soros parecem reconhecer bem um determinado antígeno, será que esses soros também seriam capazes de bloquear a adesão desse isolado antígeno específico? E será que esses soros seriam capazes de bloquear a adesão de um isolado com outro antígeno, porém com mesmo fenótipo de aderência?

Os ensaios de bloqueio de adesão foram realizados para tentar responder essas duas questões. Nossos resultados mostraram que os soros são capazes de bloquear a adesão do parasita em até cerca de $80 \%$, e também podem bloquear a adesão de outro isolado cuja VSA foi mal reconhecido inicialmente.

Os soros 517 e 477 mostraram-se mais eficientes em bloquear FMS $^{\mathrm{CD} 36}$ e Pf03, respectivamente, que possuíam os antígenos que eles mais reconheceram. Porém, esses soros foram tão eficientes quanto o soro 426 , que "deveria" bloquear melhor $38 \mathrm{~A}^{\mathrm{CD} 36} \mathrm{e}$ $38 A^{\text {ICAM }}$ (Figuras 35 e 36 ).

Estudos de Bull et al. (1998) mostraram que VSAs expressas durante episódios clínicos de malária em crianças do Quênia foram menos susceptíveis de serem reconhecidas por anticorpos preexistentes da mesma criança do que por outras crianças da mesma comunidade, entretanto, um isolado heterólogo teve a mesma probabilidade de ser reconhecido, sugerindo que a pressão seletiva exercida por anticorpos anti-PfEMP1 já estabelecidos sobre parasitas infectantes proporcionam uma proteção contra a doença.

\subsection{Hemoglobinopatia e perfil de aderência de isolados locais}

Alguns estudos propõem que a imunidade naturalmente adquirida contra a malária é mais eficiente em indivíduos portadores de HbS e HbC (Bayomi, 1987), apresentando uma melhor especificidade de resposta de IgG em crianças (Verra et al., 2007), porém, o trabalho de Tan et al. (2011) não comprovou a veracidade desses achados com crianças do Mali. De qualquer forma, apesar dos mecanismos ainda não terem sido totalmente esclarecidos, as alterações da hemoglobina podem determinar tolerância à malária, minimizando a gravidade do quadro clínico (Wambua et al., 2006), o 
que foi evidenciado em uma metanálise mostrando que $\mathrm{HbS}$ (HbAS), $\mathrm{HbC}$ (HbCC e HbAC) e a $\alpha$-talassemia conferem proteção contra a malária grave, porém apenas HbAS teve associação com a proteção à malária não complicada (Taylor et al., 2012).

Um estudo realizado no Mali, com crianças de três a onze anos de idade, encontrou um aumento da resposta de IgG a diferentes linhagens de $P$. falciparum associado ao aumento da idade apenas em crianças $\mathrm{HbAA}$ (normais) mas não em crianças HbAS e HbAC. O grupo enfatiza a importância de análises dos efeitos de hemoglobinopatias na aquisição de imunidade (Zeituni et al., 2013).

Piel et al. (2013) mostraram uma frequência de $18 \%$ de HbS em regiões da África, embora frequências acima de $20 \%$ tenha sido relatadas em pequenas amostras e em grupos étnicos específicos. Em nossos estudos encontraram apenas $2 \%$ de frequência do alelo mutado na população do Ramal do Granada.

Lawaly et al.(2010) mostraram frequências dos genótipos AS de 10\% a 13,6\%, em crianças do Senegal e Tailândia, além de relatar uma associação da HbS com um aumento da densidade de gametócitos. O aumento da produção de gametócitos em associação com a anemia falciforme já havia sido relatada em outros trabalhos (Robert et al., 1996; Trager \& Gill, 1992), com relevante importância epidemiológica, considerando que gametócitos de indivíduos com a mutação seriam mais infecciosos para os mosquitos, mesmo em densidades semelhantes (Robert et al., 1996).

Uma vez que a HbS é capaz de selecionar gametócitos mais infecciosos, é possível que a HbS também possa selecionar parasitas com alta capacidade de adesão, o que ocorreria com maior força nessas regiões onde a frequência do alelo mutado alcança altos índices na população. Lembrando que a seleção de parasitas com alta capacidade de adesão se daria, supostamente, em consequência da tentativa do parasita driblar o enfraquecimento da citoaderência aos receptores endotelias, ocasionado pela presença hemoglobinopatias na hemácia hospedeira (Cholera et al., 2008; Fairhurst et al., 2005).

Considerando que encontramos apenas $2 \%$ do alelo para $\mathrm{HbS}$, acreditamos que haja uma certa relevância para a característica de baixa virulência dos nossos isolados. Entretanto, não podemos descartar a importância do estudo de outras hemoglobinopatias, como $\mathrm{HbC}$, para uma melhor caracterização do ambiente onde o parasita circula. Para responder essa questão, poderiam ser realizados outros testes de 
aderência comparando isolados provenientes de áreas com alta e baixa prevalência de hemoglobinopatias.

É claro que muitos outros fatores ainda precisam ser analisados. Há diversos estudos, por exemplo, que associam polimorfismos da região promotora do gene das citocinas TNF- $\alpha$ e INF-y com a susceptibilidade à malária grave (González et al., 2003; Henao et al., 2006). Portadores do alelo TNF-308*A poderiam apresentar quatro vezes o risco de desenvolver a malária cerebral, e esse risco aumentaria para sete vezes para o desenvolvimento de sequelas neurológicas com a infecção (Hajeer, Hutchinson, 2001).

Embora nossos resultados tenham sido obtidos em condições experimentais (cultivo dos parasitas em Albumax) que reduzem a expressão de antígenos do tipo VSA na superfície da hemácia parasitada, mostramos neste trabalho que, mesmo sem sofrerem pressão de seleção através da anemia falciforme, os isolados da Amazônia são capazes de aderir aos receptores CD36 e ICAM-1, que e a população é capaz de reconhecer alguns desses antígenos, demonstrando aquisição de imunidade com a exposição à malária. Entretanto, várias lacunas ainda foram deixadas.

Apesar da associação de ICAM-1 com malária cerebral permanecer válida, estudos recentes focam agora no receptor EPCR como o potencial receptor responsáveis pela aderência de parasitas virulentos, que expressam PfEMP1 contendo DC8 e DC13 (associados à malária grave, incluindo a malária cerebral). Esses achados abrem um leque de possibilidades a serem testadas com amostras da Amazônia, que podem contribuir para o preenchimentos dessas lacunas, visando uma melhor compreensão não só do perfil dos nossos isolados e do padrão de resposta imune, mas também do porque os casos de malária grave são tão raros no Brasil. 
6 CONCLUSÕES 
1- Os isolados de campo provenientes da região Amazônica são capazes de aderir a CD36 e ICAM-1, com exceção de um único isolado que é knob negativo;

2- Os soros de indivíduos do Ramal do Granada foram capazes de reconhecer antígenos de superfície de hemácias parasitas, e esse reconhecimento parece ter baixa especificidade;

3- A intensidade de resposta teve correlação com o tempo de exposição na Amazônia;

4- Os soros testados, de indivíduos do Ramal do Granada, foram capazes de bloquear a adesão de eritrócitos parasitados in vitro;

5- A população de estudo apresentou $2 \%$ de frequência do alelo mutado para $\mathrm{HbS}$, corroborando com a nossa hipótese de que essa hemoglobinopatia não representa um fator de pressão seletiva de parasitas altamente adesivos no Brasil. 


\section{REFERÊNCIAS*}

Aikawa M. Morphological changes in erythrocytes induced by malarial parasites. Biol Cell. 1988;64:173-81.

Alves FP, Durlacher RR, Menezes MJ, Krieger H, Silva LH, Camargo EP. High prevalence of asymptomatic Plasmodium vivax and Plasmodium falciparum infections in native Amazonian populations. Am J Trop Med Hyg. 2002;66(6):641-8.

Alves FP, Gil LH, Marrelli MT, Ribolla PE, Camargo EP, Da Silva LH. Asymptomatic carriers of Plasmodium spp. as infection source for malaria vector mosquitoes in the Brazilian Amazon. J Med Entomol. 2005;42(5):777-9.

Anderson TJ, Su XZ, Bockarie M, Lagog M, Day KP. Twelve microsatellite markers for characterization of Plasmodium falciparum from finger-prick blood samples. Parasitology. 1999;119, 113-25.

Anderson TJ, Haubold B, Williams JT, Estrada-Franco JG, Richardson L, Mollinedo R, et al. Microsatellite markers reveal a spectrum of population structures in the malaria parasite Plasmodium falciparum. Mol Biol Evol. 2000;17(10):1467-82.

Ausubel FM, Brent R, Kingston RE, Moore DD, Deidman JG, Smith JA et al. Current Protocols in Molecular Biology. 1989.

Baker J, McCarthy J, Gatton M, Kyle DE, Belizario V, Luchavez J, Bell D, Cheng Q. Genetic diversity of Plasmodium falciparum histidine-rich protein 2 (PfHRP2) and its effect on the performance of PfHRP2-based rapid diagnostic tests. J Infect Dis. 2005;192(5):870-7.

Baruch DI, Ma XC, Singh HB, Bi X, Pasloske BL, Howard RJ. Identification of a region of PfEMP1 that mediates adherence Plasmodium falciparum infected erythrocytes to CD36: conserved function with variant sequence. Blood. 1997;90:3766-75.

Baruch DI, Rogerson SJ, Cooke BM. Asexual blood stages of malaria parasites; cytoadherence. Chem Immunol. 2002;80:144-62.

Bastos MS, da Silva-Nunes M, Malafronte RS, Hoffmann EHE, Wunderlich G, Moraes SL, Ferreira MU. Antigenic Polymorphism and Naturally Acquired Antibodies to Plasmodium vivax Merozoite Surface Protein 1 in Rural Amazonians. Clin Vaccine Immunol.2007;14:1249-59.

\footnotetext{
*De acordo com:

International Committee of Medical Journal Editors. [Internet]. Uniform requeriments for manuscripts submitted to Biomedical Journal: sample references. [updated 2011 Jul 15]. Available from: http://www.icmje.org
} 
Bayoumi RA. The sickle-cell trait modifies the intensity and specificity of the immune response against $P$. falciparum malaria and leads to acquired protective immunity. Med Hypotheses. 1987;22:287-98

Bengtsson A, Joergensen L, Rask TS, Olsen RW, Andersen MA, Turner L, Theander TG, Hviid L, Higgins MK, Craig A, Brown A, Jensen AT. A novel domain cassette identifies Plasmodium falciparum PfEMP1 proteins binding ICAM-1 and is a target of cross-reactive, adhesion-inhibitory antibodies. J Immunol. 2013;190(1):240-9.

Berendt AR, Simmons DL, Tansey J, Newbold Cl, Marsh K. Intercellular adhesion molecule1 is a endothelial cell adhesion receptor for Plasmodium falciparum. Nature. 1989;34:579.

Bonini-Domingos CR, Bonini-Domingos AC, Chinelato AR, Zamaro PJA, Calderan PHO. Interação entre Hb C [beta6(A3)Glu>Lys] e IVS II-654 (C>T) beta-talassemia no Brasil.Rev. Bras. Hematol. Hemoter.2003;25(2):115-21.

Bouharoun-Tayoun $\mathrm{H}$, Attanath $\mathrm{P}$, Sabchareon A, Chongsuphajaisiddhi T, Druilhe P. Antibodies that protect humans against Plasmodium falciparum blood stages do not on their own inhibit parasite growth and invasion in vitro, but act in cooperation with monocytes. J Exp Med. 1990;172(6):1633-41.

Bull PC, Lowe BS, Kortok M, Molyneux CS, Newbold Cl, Marsh K. Parasite antigens on the infected red cell surface are targets for naturally acquired immunity to malaria. Nat Med. 1998;4(3):358-60.

Bull PC, Marsh K. The role of antibodies to Plasmodium falciparum infected-erythrocyte surface antigens in naturally acquired immunity to malaria. Trends Microbiol. 2002;6:1113-18.

Carlos BC. Antígenos variantes de superfície de hemácias infectadas por Plasmodium falciparum na Amazônia brasileira: aderência a receptores do endotélio vascular (CD36 e ICAM-1) e reconhecimento por anticorpos. [tese (Doutorado em Parasitologia)]. São Paulo : Instituto de Ciências Biomédicas, Universidade de São Paulo; 2013.

Claessens A, Adams Y, Ghumra A, Lindergard G, Buchan CC, Andisi C, Bull PC, Mok S, Gupta AP, Wang CW, Turner L, Arman M, Raza A, Bozdech Z, Rowe JA. A subset of group A-like var genes encodes the malaria parasite ligands for binding to human brain endothelial cells. Proc Natl Acad Sci U S A. 2012;(26):1772-81.

Chan JA, Howell KB, Reiling L, Ataide R, Mackintosh CL, Fowkes FJ, Petter M, Chesson JM, Langer C, Warimwe GM, Duffy MF, Rogerson SJ, Bull PC, Cowman AF, Marsh K, Beeson JG. Targets of antibodies against Plasmodium falciparum-infected erythrocytes in malaria immunity. J Clin Invest. 2012;62182.

Chen Q, Fernandez V, Sundström A, Schlichtherle M, Datta S, Hagblom P, Wahlgren M 1998. Developmental selection of var gene expression in Plasmodium falciparum. Nature 394:392-5. 
Cholera R, Brittain NJ, Gillrie MR, Lopera-Mesa TM, Diakité SA, Arie T, et al. Impaired cytoadherence of Plasmodium falciparum-infected erythrocytes containing sickle hemoglobin. Proc Natl Acad Sci U S A. 2008;105(3):991-6.

Cooke BM, Wahlgren M, Coppel RL. Falciparum malaria: sticking-up, standing out and outstanding. Parasitology Today. 2000;16: 416-20.

Craig A, Fernandez-Reyes D, Mesri M, McDowall A, Altieri DC, Hogg N, Newbold C. A functional analysis of a natural variant of intercellular adhesion molecule-1 (ICAM-1 ${ }^{\text {Kilifi). }}$. Hum Mol Genet. 2000;9(4):525-30.

Crabb BS, Cooke BM, Reeder JC, Waller RF, Caruana SR, Davern KM, Wickham ME, Brown GV, Coppel RL, Cowman AF. Targeted gene disruption shows that knobs enable malariainfected red cells to cytoadhere under physiological shear stress. Cell. 1997;89(2):287-96.

Cserti-Gazdewich CM, Dzik WH, Erdman L, Ssewanyana I, Dhabangi A, Musoke C, Kain KC. Combined measurement of soluble and cellular ICAM-1 among children with Plasmodium falciparum malaria in Uganda. Malar J. 2010;9:233.

da Silva-Nunes M, Ferreira MU. Clinical spectrum of uncomplicated malaria in semiimmune Amazonians: beyond the "symptomatic" vs "asymptomatic" dichotomy. Mem Inst Oswaldo Cruz. 2007;102:341-7.

da Silva-Nunes M, Codeço CT, Malafronte RS, da Silva NS, Juncansen C, Muniz PT, et al. Malaria on the Amazonian frontier: transmission dynamics, risk factors, spatial distribution, and prospects for control. Am J Trop Med Hyg 2008;79:624-35.

da Silva N. S. Epidemiologia da malária: incidência, distribuição espacial e fatores de risco em uma coorte rural amazônica. [tese (Doutorado em Parasitologia)]. São Paulo: Instituto de Ciências Biomédicas da Universidade de São Paulo; 2011.

Datasus. Banco de dados do SUS. Brasília: Ministério da Saúde; 2005. Disponível em $<$ http://www.datasus.gov.br>.

Doolan DL, Dobaño C, Baird JK. Acquired immunity to malaria. Clin Microbiol Rev. 2009; 22(1):13-36, Table of Contents. doi: 10.1128/CMR.00025-08. Review.

Elliott SR, Payne PD, Duffy MF, Byrne TJ, Tham WH, Rogerson SJ, Brown GV, Eisen DP. Antibody recognition of heterologous variant surface antigens after a single Plasmodium falciparum infection in previously naive adults. Am J Trop Med Hyg. 2007;76(5):860-904.

Fairhurst RM, Baruch DI, Brittain NJ, Ostera GR, Wallach JS, Hoang HL et al. Abnormal display of PfEMP-1 on erythrocytes carrying haemoglobin $\mathrm{C}$ may protect against malaria. Nature. 2005;435:1117-21.

Feng G, Aitken E, Yosaatmadja F, Kalilani L, Meshnick SR, Jaworowski A, Simpson $\mathrm{JA}$, Rogerson SJ. Antibodies to variant surface antigens of Plasmodium falciparum- 
infected erythrocytes are associated with protection from treatment failure and the development of anemia in pregnancy. J Infect Dis. 2009;200(2):299-306.

Ferreira MU, da Silva-Nunes M. Malária. In: Lopes AC, editor. Tratado de clínica médica. São Paulo: Roca; 2009. vol. 3, p. 4114-22.

Ferreira MU, Kimura EA, Katzin AM, Santos-Neto LL, Ferrari JO, Villalobos JM et al. The IgG-subclass distribution of naturally acquired antibodies to Plasmodium falciparum, in relation to malaria exposure and severity. Ann Trop Med Parasitol. 1998;92(3):245-56.

Fonager J, Pasini EM, Braks JA, Klop O, Ramesar J, Remarque EJ, Vroegrijk IO, van Duinen SG, Thomas AW, Khan SM, Mann M, Kocken CH, Janse CJ, Franke-Fayard BM. Reduced CD36-dependent tissue sequestration of Plasmodium-infected erythrocytes is detrimental to malaria parasite growth in vivo. J Exp Med. 2012;209(1):93-107.

Frankland S, Elliott SR, Yosaatmadja F, Beeson JG, Rogerson SJ, Adisa A, Tilley L. Serum lipoproteins promote efficient presentation of the malaria virulence protein PfEMP1 at the erythrocyte surface. Eukaryot Cell. 2007;6(9):1584-94.

Fry $A E$, Auburn S, Diakite $M$, Green A, Richardson A, Wilson J, Jallow M, Sisay-Joof $F$, Pinder M, Griffiths MJ, Peshu N, Williams TN, Marsh K, Molyneux ME, Taylor TE, Rockett KA, Kwiatkowski DP. Variation in the ICAM1 gene is not associated with severe malaria phenotypes. Genes Immun. 2008;9(5):462-9.

Gamboa D, Ho MF, Bendezu J, Torres K, Chiodini PL, Barnwell JW, Incardona S, Perkins M, Bell D, McCarthy J, Cheng Q. A large proportion of $P$. falciparum isolates in the Amazon region of Peru lack pfhrp2 pfhrp3: implications for malaria rapid diagnostic tests. PLoS One 2010; 5:e8091.

Giha HA, Staalsoe T, Dodoo D, Roper C, Satti GM, Arnot DE et al. Antibodies to variable Plasmodium falciparum-infected erythrocyte surface antigens are associated with protection from novel malaria infections. Immunol Lett. 2000;71(2):117-26.

Gray C, McCormick C, Turner G, Craig A. ICAM-1 can play a major role in mediating P. falciparum adhesion to endothelium under flow. Mol Biochem Parasitol. 2003;128(2):18793.

González S, Rodrigo L, Martínez-Borra J, López-Vázquez A, Fuentes D, Niño P, Cadahía V, Saro C, Dieguez MA, López-Larrea C. TNF-alpha -308A promoter polymorphism is associated with enhanced TNF-alpha production and inflammatory activity in Crohn's patients with fistulizing disease. Am J Gastroenterol. 2003;98(5):1101-06.

Gupta S, Snow RW, Donnelly CA, Marsh K, Newbold C. Immunity to non-cerebral severe malaria is acquired after one or two infections. Nat Med. 1999;5(3):340-3.

Gysin J, Moisson P, Pereira da Silva L, Druilhe P. Antibodies from immune African donors with a protective effect in Plasmodium falciparum human infection are also able to 
control asexual blood forms of the parasite in Saimiri monkeys. Res Immunol. 1996;147(6):397-401.

Hajeer AH, Hutchinson IV. Influence of TNFalpha gene polymorphisms on TNFalpha production and disease. Hum Immunol. 2001;62(11):1191-99.

Henao MI, Montes C, París SC, García LF. Cytokine gene polymorphisms in Colombian patients with different clinical presentations of tuberculosis. Tuberculosis (Edinb). 2006;86(1):11-19.

Heddini A, Pettersson F, Kai O, Shafi J, Obiero J, Chen Q, Barragan A, Wahlgren M, Marsh K. Fresh isolates from children with severe Plasmodium falciparum malaria bind to multiple receptors. Infect Immun. 2001;69(9):5849-56.

Horrocks P, Pinches RA, Chakravorty SJ, Papakrivos J, Christodoulou Z, Kyes SA, Urban BC, Ferguson DJ, Newbold Cl. PfEMP1 expression is reduced on the surface of knobless Plasmodium falciparum infected erythrocytes. J Cell Sci. 2005;118:2507-18.

Jensen AT, Magistrado P, Sharp S, Joergensen L, Lavstsen T, Chiucchiuini A, Salanti A, Vestergaard LS, Lusingu JP, Hermsen R, Sauerwein R, Christensen J, Nielsen MA, Hviid L, Sutherland C, Staalsoe T, Theander TG. Plasmodium falciparum associated with severe childhood malaria preferentially expresses PfEMP1 encoded by group A var genes. J Exp Med. 2004;199(9):1179-90.

Joergensen L, Bengtsson DC, Bengtsson A, Ronander E, Berger SS, Turner L, Dalgaard MB, Cham GK, Victor ME, Lavstsen T, Theander TG, Arnot DE, Jensen AT. Surface co-expression of two different PfEMP1 antigens on single plasmodium falciparum-infected erythrocytes facilitates binding to ICAM1 and PECAM1. PLoS Pathog. 2010;6(9):e1001083.

Jurzynski C, Gysin J, Pouvelle B. CD44, a signal receptor for the inhibition of the cytoadhesion of CD36-binding Plasmodium falciparum-infected erythrocytes by CSAbinding infected erythrocytes. Microbes Infect. 2007;9:1463.

Khaw LT, Ball HJ, Golenser J, Combes V, Grau GE, Wheway J, Mitchell AJ, Hunt NH. Endothelial cells potentiate interferon- $\psi$ production in a novel tripartite culture model of human cerebral malaria. PLoS One. 2013;8(7):e69521.

Kilejian A. Characterization of a protein correlated with the production of knob-like protrusions on membranes of erythrocytes infected with Plasmodium falciparum. Proc Natl Acad Sci U S A. 1979;76(9):4650-53.

Kraemer SM, Gupta L, Smith JD. New tools to identify var sequence tags and clone fulllength genes using type-specific primers to Duffy binding-like domains. Mol Biochem Parasitol. 2003;129(1):91-102.

Kraemer SM, Smith JD. A family affair: var genes, PfEMP1 binding, and malaria disease. Curr Opin Microbiol. 2006;9(4):374-80. 
Ladeia-Andrade S, Ferreira MU, de Carvalho ME, Curado I, Coura JR. Age-dependent acquisition of protective immunity to malaria in riverine populations of the Amazon Basin of Brazil. Am J Trop Med Hyg. 2009;80(3):452-9.

Lavstsen T, Salanti A, Jensen AT, Arnot DE, Theander TG. Sub-grouping of Plasmodium falciparum 3D7 var genes based on sequence analysis of coding and non-coding regions. Malar J. 2003;2:27.

Lavstsen T, Turner L, Saguti F, Magistrado P, Rask TS, Jespersen JS, Wang CW, Berger SS, Baraka V, Marquard AM, Seguin-Orlando A, Willerslev E, Gilbert MT, Lusingu J, Theander TG. Plasmodium falciparum erythrocyte membrane protein 1 domain cassettes 8 and 13 are associated with severe malaria in children. Proc Natl Acad Sci U S A. 2012;109(26):E1791-800.

Lawaly YR, Sakuntabhai A, Marrama L, Konate L, Phimpraphi W, Sokhna C, Tall A, Sarr FD, Peerapittayamongkol C, Louicharoen C, Schneider BS, Levescot A, Talman A, Casademont I, Menard D, Trape JF, Rogier C, Kaewkunwal J, Sura T, Nuchprayoon I, Ariey F, Baril L, Singhasivanon P, Mercereau-Puijalon $O$, Paul R. Heritability of the human infectious reservoir of malaria parasites. PLoS One. 2010; 5(6):e11358

Leech JH, Aley SB, Miller LH, Howard RJ. Plasmodium falciparum malaria: cytoadherence of infected erythrocyte to endothelial cell and associated changes in the erythrocyte membrane. Prog Clin Biol Res. 1984;155:63-77.

Li A, Lim TS, Shi H, Yin J, Tan SJ, Li Z, Low BC, Tan KS, Lim CT. Molecular mechanistic insights into the endothelial receptor mediated cytoadherence of Plasmodium falciparum-infected erythrocytes. PLoS One. 2011;6(3):e16929.

Ljungström I, Perlmann H, Schlichtherle M, Scherf A, Wahlgren M. Methods in malaria research. 4. ed. Manassas, Virginia: MR4/ATCC; 2004.

Ma C, Harrison P, Wang L, Coppel RL. Automated estimation of parasitaemia of Plasmodium yoelii-infected mice by digital image analysis of Giemsa-stained thin blood smears. Malar J. 2010;9:348.

Manning L, Laman M, Stanisic D, Rosanas-Urgell A, Bona C, Teine D, Siba P, Mueller I, Davis TM. Plasma Plasmodium falciparum Histidine-Rich Protein-2 Concentrations Do Not Reflect Severity of Malaria in Papua New Guinean Children. Clin Infect Dis. 2011;52(4):440-46.

Mardani A, Keshavarz $H$, Heidari A, Hajjaran H, Raeisi A, Khorramizadeh MR. Genetic polymorphism at the C-terminal domain (region III) of knob-associated histidine-rich protein (KAHRP) of Plasmodium falciparum in isolates from Iran. Parasitol Res. 2011;109(6):1647-52.

Marsh K, Snow RW. Host-parasite interaction and morbidity in malaria endemic areas. Philos Trans R Soc Lond B Biol Sci. 1997;352(1359):1385-94. 
Marti M, Baum J, Rug M, Tilley L, Cowman AF. Signal-mediated export of proteins from the malaria parasite to the host erythrocyte. J Cell Biol. 2005;171(4): 587-92

Mayor A, Serra-Casas E, Rovira-Vallbona E, Jiménez A, Quintó L, Sigaúque B, Dobaño C, Bardají $\mathrm{A}$, Alonso $\mathrm{PL}$, Menéndez $\mathrm{C}$. Immunoglobulins against the surface of Plasmodium falciparum-infected erythrocytes increase one month after delivery. Malar J. 2012;25( 11):130.

McCormick CJ, Craig A, Roberts D, Newbold Cl, Berendt AR. Intercellular adhesion molecule-1 and CD36 synergize to mediate adherence of Plasmodium falciparum-infected erythrocytes to cultured human microvascular endothelial cells.J Clin Invest. 1997;100(10):2521-9.

Muanza K, Gay F, Behr C, Scherf A. Primary culture of human lung microvessel endothelial cells: a useful in vitro model for studying Plasmodium falciparum-infected erythrocyte cytoadherence. Res Immunol. 1996;147(3):149-63.

Myakishev MV, Khripin Y, Hu S, Hamer DH: High-throughput SNP genotyping by allelespecific PCR with universal energy-transfer-labeled primers. Genome Res. 2001;11:163169.

Nielsen MA, Staalsoe T, Kurtzhals JA, Goka BQ, Dodoo D, Alifrangis M, Theander TG, Akanmori BD, Hviid L. Plasmodium falciparum variant surface antigen expression varies between isolates causing severe and nonsevere malaria and is modified by acquired immunity. J Immunol. 2002;168(7):3444-50.

Ochola LB, Siddondo BR, Ocholla H, Nkya S, Kimani EN, Williams TN, Makale JO, Liljander A, Urban BC, Bull PC, Szestak T, Marsh K, Craig AG. Specific receptor usage in Plasmodium falciparum cytoadherence is associated with disease outcome. PLoS One. 2011;6(3):e14741.

Orjuela-Sanchez P, Brandi MC, Ferreira MU. Microsatellite analysis of malaria parasites. In: Kantartzi SK. Microsatellites: Methods and protocols, methods in molecular biology. Carbondale: Humana Press; 2013. p. 247-58.

Oleinikov AV, Amos E, Frye IT, Rossnagle E, Mutabingwa TK, Fried M, Duffy PE. High throughput functional assays of the variant antigen PfEMP1 reveal a single domain in the 3D7 Plasmodium falciparum genome that binds ICAM1 with high affinity and is targeted by naturally acquired neutralizing antibodies. PLoS Pathog. 2009;5(4):e1000386.

Pan American Health Organization. Malaria: Progress Report 2007. Washington, DC: Pan American Health Organization; 2008.

Phiri H, Montgomery J, Molyneux M, Craig A. Competitive endothelial adhesion between Plasmodium falciparum isolates under physiological flow conditions. Malar J. 2009;8:214. 
Piel FB, Patil AP, Howes RE, Nyangiri OA, Gething PW, Dewi M, Temperley WH, Williams TN, Weatherall DJ, Hay SI. Global epidemiology of sickle haemoglobin in neonates: a contemporary geostatistical model-based map and population estimates. Lancet. 2013 12;381(9861):142-51.

PongponratnE, Riganti M, PunpoowongB, Aikawa M. Microvascular sequestration of parasitized erythrocytes in human falciparum malaria: a pathological study. Am J Trop Med Hyg. 1991;44(2):168-75.

Pouvelle B, Buffet PA, Lepolard C, Scherf A, Gysin J. Cytoadhesion of Plasmodium falciparum ring-infected erytrocytes. Nat Med. 2000;6(11):1264-68.

Roll Back Malaria (RBM). Global Malaria Action Plan. 2008. [citado 2012 jan 10]. Disponível em: http://www.rbm.who.int/.

Rowe JA, Scragg IG, Kwiatkowski D, Ferguson DJ, Carucci DJ, Newbold CI. Implications of mycoplasma contamination in Plasmodium falciparum cultures and methods for its detection and eradication. Mol Biochem Parasitol. 1998;92(1):177-80.

Rowe JA, Claessens A, Corrigan RA, Arman M. Adhesion of Plasmodium falciparuminfected erythrocytes to human cells: molecular mechanisms and therapeutic implications. Expert Rev Mol Med. 2009;11:e16.

Rug M, Prescott SW, Fernandez KM, Cooke BM, Cowman AF. The role of KAHRP domains in knob formation and cytoadherence of $P$ falciparum-infected human erythrocytes. Blood. 2006;108(1):370-78.

Rusch TL, Dickinson W, Che J, Fieweger K, Chudyk J, Doktycz M, Yu A, Weber JL. Instrumentation for Continuous Array Genotyping of Short Insert/Deletion Polymorphisms. Proceedings of the SPIE - Microarrays and Combinatorial Technologies for Biomedical Applications: Design, Fabrication, and Analysis. 2003;4966:138-45.

Scopel KK, da Silva-Nunes M, Malafronte RS, Braga EM, Ferreira MU. Variant-specific antibodies to merozoite surface protein 2 and clinical expression of Plasmodium falciparum malaria in rural Amazonians. Am J Trop Med Hyg. 2007;76:1084-91.

Scherf A, Hernandez-Rivas R, Buffet P, Bottius E, Benatar C, Pouvelle B, Gysin J, Lanzer M 1998. Antigenic variation in malaria: in situ switching, relaxed and mutually exclusive transcription of var genes during intra-erythrocytic development in Plasmodium falciparum. EMBO J 17:5418-26.

Silva WS, Lastra A, de Oliveira SF, Klautau-Guimarães N, Grisolia CK. Evaluation of coverage by a neonatal screening program for hemoglobinopathies in the Recôncavo region of Bahia, Brazil. Cad Saúde Pública. 2006;22:2561-6.

Sio SW, Sun W, Kumar S, Bin WZ, Tan SS, Ong SH, Kikuchi H, Oshima Y, Tan KS. Malaria Count: an image analysis-based program for the accurate determination of parasitemia. J Microbiol Methods. 2007;68(1):11-8. 
Smith JD, Chitnis CE, Craig AG, Roberts DJ, Hudson-Taylor DE, Peterson DS et al. Switches in expression of Plasmodium falciparum var genes correlate with changes in antigenic and cytoadherent phenotypes of infected erythrocytes. Cell. 1995;82:101-10.

Sonati MF, Costa FF. The genetics of blood disorders: hereditary hemoglobinopathies. J Pediatr (Rio J). 2008;84(4 Suppl):S40-51.

Tan X, Traore B, Kayentao K, Ongoiba A, Doumbo S, Waisberg M, Doumbo OK, Felgner PL, Fairhurst RM, Crompton PD. Hemoglobin $S$ and $C$ heterozygosity enhances neither the magnitude nor breadth of antibody responses to a diverse array of Plasmodium falciparum antigens. J Infect Dis. 2011;204(11):1750-61.

Taylor SM, Parobek CM, Fairhurst RM. Impact of haemoglobinopathies on the clinical epidemiology of malaria: a systematic review and meta-analysis. Lancet Infect Dis. 2012; 12(6): 457-68.

Trager W, Gill GS. Enhanced gametocyte formation in young erythrocytes by Plasmodium falciparum in vitro. J Protozool. 1992; 39(3):429-32.

Trager W, Jansen JB. Human malaria parasites in continuous culture. Science. 1976;193:673-5.

van de Stolpe A, van der Saag PT. Intercellular adhesion molecule-1. J Mol Med. 1996;74:13-33.

Verra F, Simpore J, Warimwe GM, Tetteh KK, Howard T, Osier FH, Bancone G, Avellino P, Blot I, Fegan G, Bull PC, Williams TN, Conway DJ, Marsh K, Modiano D. Haemoglobin C and Srole in acquired immunity against Plasmodium falciparum malaria. PLoS One. 2007;2(10):e978.

Wahlgren M, Treutiger CJ, Gysin J. Cytoadherence and rosetting in the pathogenesis of severe malaria. In: Wahlgren M, Perlmann P, editor. Malaria: molecular and clinical aspects. Amsterdam: Harwood Academic Press; 1999. p. 289-327.

Waller KL, Cooke BM, Nunomura W, Mohandas N, Coppel RL. Mapping the binding domains involved in the interaction between the Plasmodium falciparum knob-associated histidine-rich protein (KAHRP) and the cytoadherence ligand $P$. falciparum erythrocyte membrane protein 1 (PfEMP1). J Biol Chem. 1999;274(34):23808-13.

Walliker D, Quakyi IA, Wellems TE, McCutchan TF, Szarfman A, London WT, Corcoran LM, Burkot TR, Carter R.Genetic analysis of the human malaria parasite Plasmodium falciparum. Science. 1987;236(4809):1661-6.

Wambua S, Mwangi TW, Kortok M, Uyoga SM, Macharia AW, Mwacharo JK, Weatherall DJ, Snow RW, Marsh K, Williams TN. The effect of alpha+-thalassaemia on the incidence 
of malaria and other diseases in children living on the coast of Kenya. PLoS Med. 2006;3(5):e158.

Warrell DA. Cerebral malaria. Schweiz Med Wochenschr. 1992;122(23):879-86.

World Health Organization (WHO).World malaria Report. Geneva. 2010.

World Heath Organization (WHO). 2011. [cited 2012 jan 10]. Disponível em: http://www.who.int/features/factfiles/malaria/en/index.html.

Zeituni AE, Miura K, Diakite M, Doumbia S, Moretz SE, Diouf A, Tullo G, Lopera-Mesa TM, Bess CD, Mita-Mendoza NK, Anderson JM, Fairhurst RM, Long CA. Effects of Age, Hemoglobin Type and Parasite Strain on IgG Recognition of Plasmodium falciparumInfected Erythrocytes in Malian Children. PLoS One. 2013;8(10): e76734.

Zhang Q, Zhang Y, Huang Y, Xue X, Yan H, Sun X, Wang J, McCutchan TF, Pan W. From in vivo to in vitro: dynamic analysis of Plasmodium falciparum var gene expression patterns of patient isolates during adaptation to culture. PLoS One. 2011;6(6):e20591. 